\title{
Displaced Mixed-Blood: An Ethnographic Exploration of Métis Identities in Nova Scotia
}

\author{
by
}

Katie K. MacLeod

A thesis submitted to the Faculty of Graduate and Postdoctoral Affairs in partial fulfillment of the requirements for the degree of

Master of Arts

in

Anthropology

Carleton University

Ottawa, Ontario

(C) 2013, Katie K. MacLeod 
Library and Archives

Canada

Published Heritage

Branch

395 Wellington Street

Ottawa ON K1A ON4

Canada
Bibliothèque et

Archives Canada

Direction du

Patrimoine de l'édition

395 , rue Wellington

Ottawa ON K1A ON4

Canada
Your file Votre référence

ISBN: 978-0-494-94589-6

Our file Notre référence

ISBN: 978-0-494-94589-6
NOTICE:

The author has granted a nonexclusive license allowing Library and Archives Canada to reproduce, publish, archive, preserve, conserve, communicate to the public by telecommunication or on the Internet, loan, distrbute and sell theses worldwide, for commercial or noncommercial purposes, in microform, paper, electronic and/or any other formats.

The author retains copyright ownership and moral rights in this thesis. Neither the thesis nor substantial extracts from it may be printed or otherwise reproduced without the author's permission.
AVIS:

L'auteur a accordé une licence non exclusive permettant à la Bibliothèque et Archives Canada de reproduire, publier, archiver, sauvegarder, conserver, transmettre au public par télécommunication ou par l'Internet, prêter, distribuer et vendre des thèses partout dans le monde, à des fins commerciales ou autres, sur support microforme, papier, électronique et/ou autres formats.

L'auteur conserve la propriété du droit d'auteur et des droits moraux qui protege cette thèse. $\mathrm{Ni}$ la thèse ni des extraits substantiels de celle-ci ne doivent être imprimés ou autrement reproduits sans son autorisation.
In compliance with the Canadian Privacy Act some supporting forms may have been removed from this thesis.

While these forms may be included in the document page count, their removal does not represent any loss of content from the thesis.
Conformément à la loi canadienne sur la protection de la vie privée, quelques formulaires secondaires ont été enlevés de cette thèse.

Bien que ces formulaires aient inclus dans la pagination, il n'y aura aucun contenu manquant. 


\begin{abstract}
With recent resurgences of Métis recognition in Canada there have been increasingly more opportunities for self-identifying Métis to gain legal recognition from the Canadian State. Although the Maritimes has not been viewed as a region with a Métis presence in the past, there are various populations present that are searching for this recognition. This study explores the historic mixed-blood that is present among the self-identifying Métis in Nova Scotia. I explore the way these Métis identities are contextualized in Canada though history, law, and Indigenous-settler relations. Particularly, I provide an analysis of Métis identification in Nova Scotia though genealogy, language, colonialism and denial. Lastly, this study shows the struggles the Métis face when positioning themselves within constitutional categories in an effort to be acknowledged as Aboriginal Peoples in Canada.
\end{abstract}




\section{Acknowledgements}

This project would not have been possible without the support of many people,

I would like to thank the Department of Sociology and Anthropology at Carleton University, learning from and working with the faculty and staff has been inspiring and has increased my knowledge and in many ways pushed me to see my project from new perspectives.

I would like to thank my supervisors; Dr. Donna Patrick for her willingness to offer knowledge, attention and advice; and Dr. Siomonn Pulla for his help navigating the complexities of the Canadian political-legal domain, guidance and encouragement. I am eternally grateful for the support you both provided through the challenges, fieldwork, analysis and writing of this thesis. I would also like to thank my external examiner Dr. Michel Hogue for his time, insight and comments.

I would like to thank all those who participated in my project in various capacities. In particular I would like to thank members of the Métis organizations, Kespu'kwitk Métis Council, l'Association des Acadien-Métis Souriquois and Sou'west Nova Métis Council, without your consultation and collaboration this project would not have been possible. It was a pleasure to hear and tell your stories.

I would like to thank my family, for instilling in me a thirst for knowledge and a dedication to hard work; my grandparents for never letting me forget the importance of being Acadian and an endless curiosity in the identity and it's many complexities; my mother and father for providing me with endless support and guidance and my brother for being a friend and source of laughter.

I would like to thank my friends and extended family for providing encouragement, and unwavering support.

I would like to thank my fellow graduate students; you provided me with a diverse learning environment, valuable insight and lasting friendships. 


\section{Table of Contents}

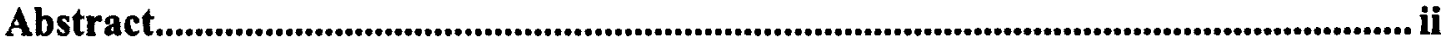

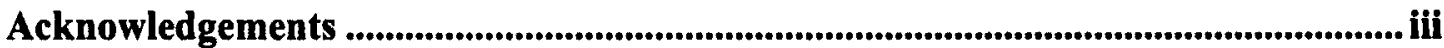

List of Tables ................................................................................................................... vi

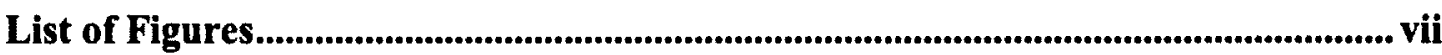

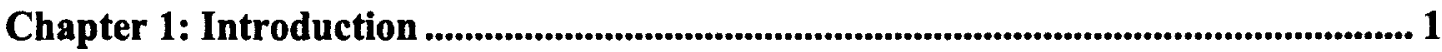

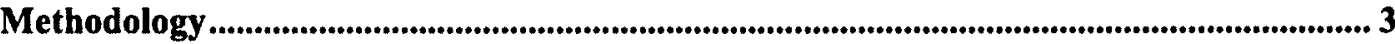

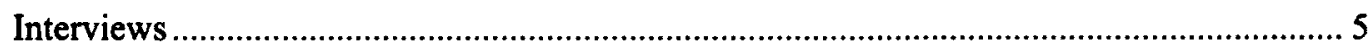

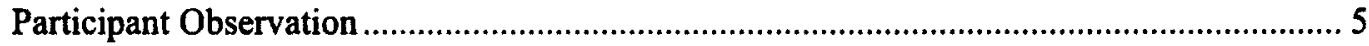





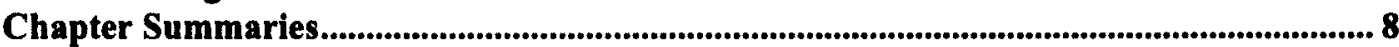

Chapter 2: Who are the Métis in Nova Scotia? Building an Ethnohistorical Context

Metis Identities in

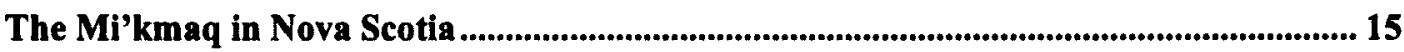

French Settlement and the Acadians in Nova Scotia...................................................................... 18



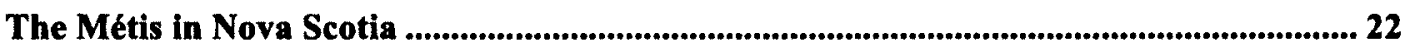

The Legal Context for Métis in Nova Scotia ........................................................................... 27

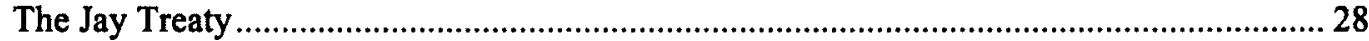

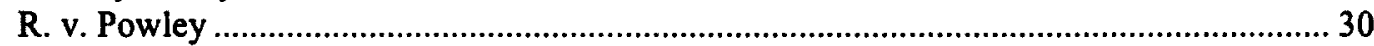

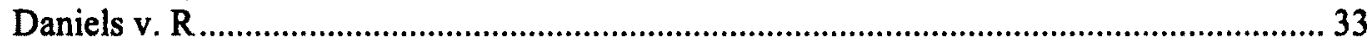

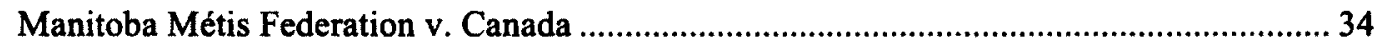

Fitting Into the Legal Context: Challenges and Opportunities.............................................. 34

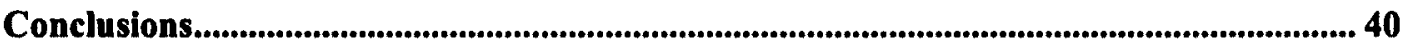

Chapter 3: An Ethnographic Study of Métis ......................................................................... 42

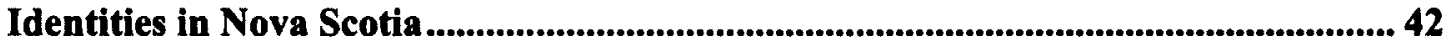

"Plane un aige" ................................................................................................................................. 42

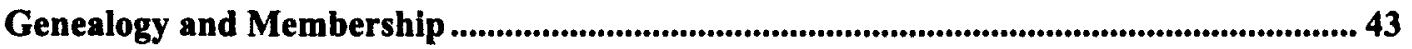

Relationship to Land, Animals and Waters ........................................................................ 58

Language, Relations and Respect................................................................................................. 75



Chapter 4: Categorization of Métis Identities in Nova Scotia ..................................... 98

"Métisness" in Nova Scotia ...................................................................................................................... 99

Community or Collective? ........................................................................................................ 103

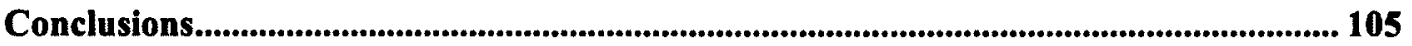


Chapter 5: Conclusion .................................................................................................................. 107

Bibliography ................................................................................................................................ 113

Appendix A: Sample Interview Questions: Métis......................................................... 121

Appendix B: Sample Interview Questions: Acadians....................................................... 122

Appendix C: Sample Interview Questions: Mi'kmaq .................................................... 123

Appendix D: Consent form for all participants ................................................................... 124

Appendix E: Oral Consent Script ............................................................................................. 127

Appendix F: Termes Amérindiens dans le Parler Acadien ............................................. 128

Appendix G: Termes Acadien dans le Parler Mi'kmaq..................................................... 130

Appendix H: Wampano-Quiripi Vocabulary................................................................... 132 


\section{List of Tables}

Table 1: Métis Presence in Southwestern Nova Scotia

Table 2: The Birth of the Acadien Language, Acadien depicted through phonetics

Table 3: Linguistic similarities between Acadien and Mi'kmaq

Table 4: Mi'kmaq derived Acadien terms 


\section{List of Figures}

Figure 1: Map of Nova Scotia, divided into counties

Figure 2: Mi'kma'ki

Figure 3: Fish Weir (a'bilokteg'an/Nijag'an) Operation

Figure 4: Fish Weir (a'bilokteg'an/Nijag'an), Quinan, Nova Scotia

Figure 5: Eel Pot, Tuna Museum, Wedgeport, Nova Scotia

Figure 6: Goose Light, Cape Sable Island, late 1800's

Figure 7: Meat/Meet Rock (La Roche de Viande) Myths, Quinan, Nova Scotia

Figure 8: Meat/Meet Rock (La Roche de Viande), Quinan, Nova Scotia

Figure 9: Flags at Mi'kmaq-Acadian Festival, LaHave, Nova Scotia 


\section{Chapter 1: Introduction}

In this thesis I explore historic Métis bloodlines in contemporary Nova Scotia and how individuals and collectives are beginning to use this category to define their identities as Métis in line with early métissage in the province. Research was conducted in consultation with three Métis organizations: the Kespu'kwitk Métis Council, l'Association des Acadien-Métis Souriquois and the Sou'west Nova Métis Council, also known as the Nova Scotia Wampanoag. This research raises questions of Indigeneity, cultural denial, subsistence and the current state of settler-Indigenous relations in the Maritime Provinces. The cultural indications of métissage, which comes through in my ethnographic data, shed light on what it is to be a Métis in Nova Scotia. This thesis ultimately asks four questions: Who are the Métis in the Nova Scotia? How do they define themselves? How do they identify as Métis and why? And how is métissage represented in cultural components of identity?

One afternoon, during my fieldwork, I was invited to the Shelbourne's Founders Day Festival by the members of the Sou'west Nova Métis Council to participate in an Aboriginal exhibition they were co-hosting with local members of the Native Council of Nova Scotia. After a bit of time participating in the events and the various workshops they were holding, Deborah, a Mi'kmaq woman pulled me aside to talk. As she began filling a bowl full of moose meat for me to try she said, "How'd you get to be researching Métis in Nova Scotia? ...There aren't any Métis in Nova Scotia." 
Mildly taken aback, but not unaware of the feelings some Mi'kmaq Peoples have towards the Métis movement, I felt conflicted and responded, “...but there are many here who identify as Métis." Deborah took a moment and expressed:

Some people on the Native Council of Nova Scotia become upset with me when I talk about working with the Métis groups; the term bothers us because the Mi'kmaq culture is really mixed and we are non-status. When we work with the Métis we prefer to use the term Aboriginal, because we work with them and we are friends. ${ }^{\prime}$

A great deal of controversy and contention exists in the province of Nova Scotia around the term Métis and the implications this term generates for the Métis organizations and self-identifying Métis within these intertwined histories. The inescapable reality in the province is that there are 7,680 individuals who self-identify as Métis (Statistics Canada, Population Census 2006) and they want to be heard.

The category of Métis being used in the Maritimes brings with it an overwhelming air of contention and at times hostility from both Aboriginal and settler populations. Early on in my study, one participant, Tom, a member of Sou'west Nova Métis Council, said to me, "Well sometimes we feel like we can't figure out who we are and what we should be called, so maybe you can tell us." I didn't think much of this statement at first and assumed he was joking. However, as my study progressed and the complications emerged, I realized that what he was referring to was the problem of categories when defining identities in Southwestern Nova Scotia. After spending a month asking many self-identifying Métis probing questions about their identities, customs and politics, another participant, Léon, a member of the Kespu'kwitk Métis Council, finally bluntly said what I was trying to wrap my head around - Métis is just a new buzz word to

\footnotetext{
' Participant Interview, July 20, 2012.

${ }^{2}$ Participant Interview, July 15, 2012.
} 
describe what they have always seen themselves as, it was a category, and a problematic one at that.

\section{Methodology}

The Métis identities in Nova Scotia derive from two contexts: first from the French settlement and the ethnogenesis of the Acadians on mainland Nova Scotia; and secondly, from the English and Wampanoag settlement of Cape Sable Island, located off the southernmost point of the Nova Scotia mainland. The political complexities, contradictions and differences that exist between various organizations became clear quickly as I began to undertake fieldwork. However, despite these differences, they all face the same pressures. This includes a shared history of the colonial environment in Nova Scotia and the constraints that have been placed on them by Canadian law and constitutional definitions. In particular, they have a common goal to bring Métis identity in the Maritimes in conversation with national recognition of the Métis in Canada.

I conducted multi-sited fieldwork in Nova Scotia among self-identifying Métis, Acadians, and Mi'kmaq. The study spanned a geographic area of three provincial counties: Digby County, Yarmouth County and Shelbourne County, which include the Municipalities of Clare, Yarmouth, Argyle and Barrington (See Figure 1). I conducted research with three Métis organizations in this region: L'Association Acadien-Métis Souriquois, Sou'west Nova Métis Council and Kespu'kwitk Métis Council. The duration of fieldwork was four months with research commencing in July 2012 and completed in October 2012. 


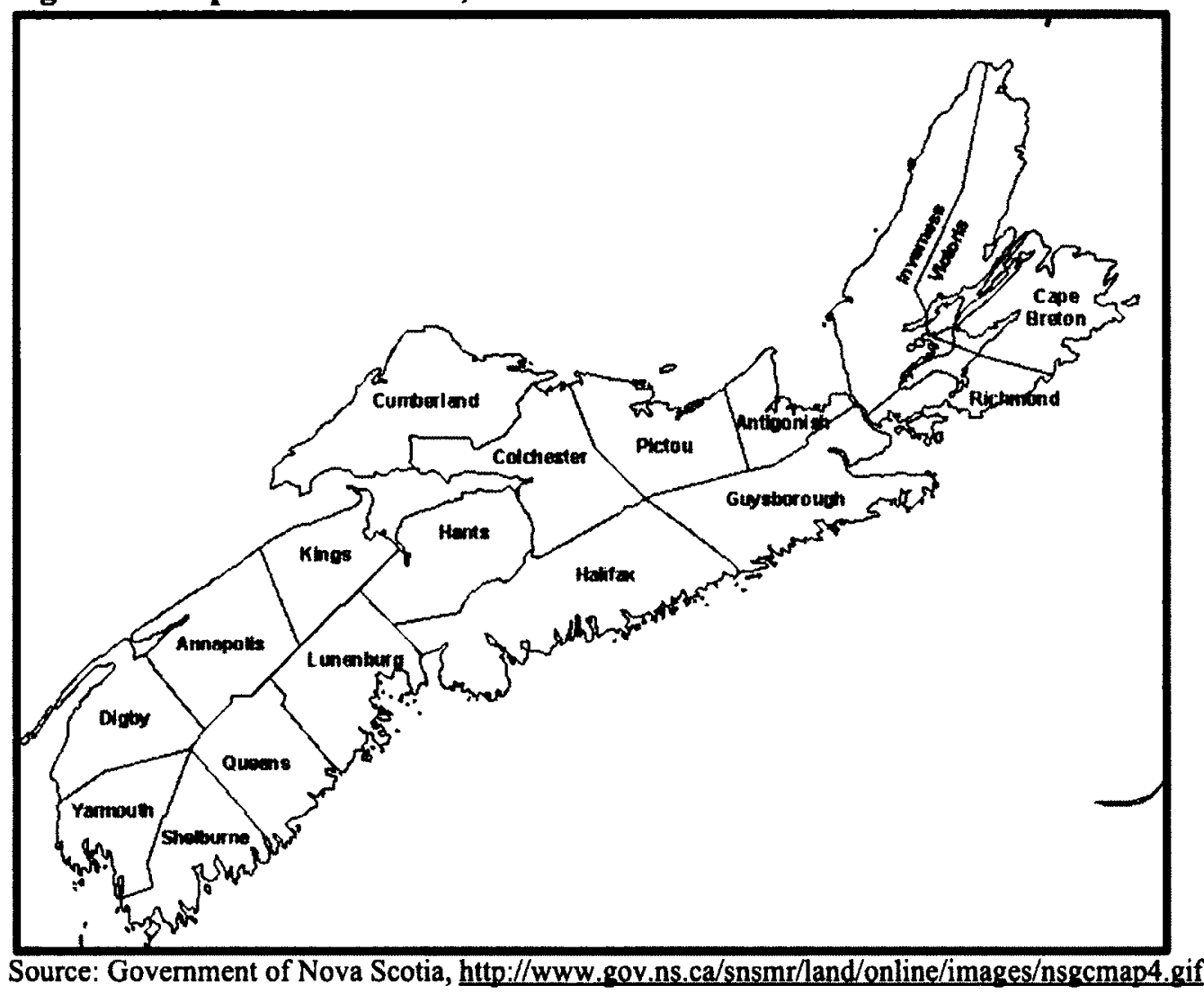

Prior to my fieldwork I conducted preliminary research with the Maritime Aboriginal Peoples Council (MAPC) and the Congress of Aboriginal Peoples (CAP) in Ottawa. CAP allowed me to access their material on their Powley Implementation Project (PIP) in the Maritimes and various other supporting documents that relate to the project. I also completed a substantial review of documents produced on Métis issues in the Maritimes, allowing me to supplement my ethnographic data with case material on Métis in both Nova Scotia and New Brunswick, as well as Métis elsewhere in Canada. 


\section{Interviews}

My primary method of research was semi-structured interviews with Métis, Acadians, and Mi'kmaq in Nova Scotia. I interviewed 22 people who self-identified as Métis, 4 who self-identified as Acadian, and 7 who self-identified as Mi'kmaq. Some who selfidentified as Métis also identified as Acadian; and 4 of the self-identifying Métis are not members of an organization. Participants were between the ages of 22 and 85 . Thirteen participants were female and twenty were male. Some of these interviews were less structured conversations as they occurred in less conventional locations or at various events I attended. Interviews lasted between 15 and 120 minutes. Multiple interviews involved more than one individual.

Interviews inquired about the early history and known interactions that occurred between indigenous and settler groups as well as what the current relationships are like between the various populations in the region. Interview questions (see appendix A, B \& C for lists of questions asked) prompted participants to recount stories and oral histories about their families, community, views about Métis status in the Maritimes, and participation in the culture of the group to which they belong. All participants were asked to provide their opinion on the possibility of Métis recognition in the Maritimes and how they see this affecting the region and the impacts this could have on the populations.

\section{Participant Observation}

Participant observation for this project involved actively participating in events and reflecting upon observed behaviour, conduct, and non-verbal actions of participants while in the presence of the researcher. I attended Festival Acadien de Clare, Shelbourne's 
Founders Day Festival, and the Mi'kmaq-Acadian Festival in LaHave. I recorded extensive field notes based on my observations. I also visited Grand-Pré National Historic Site and Port Royal on July 22 for their celebration on National Acadian Day, along with the Métis Heritage site, Meat Rock or La Roche de Viande, in Quinan, Nova Scotia. Additionally, I visited Musée Acadien at Rendez-vous-à-la-Baie, in Church Point, Village Acadien and Musée Acadien in Pubnico, and the Tusket Islands to examine Métis representation and participation.

\section{A Collaborative Approach}

This project involved conducting research among various groups of self-identifying Aboriginal Peoples. Remaining conscious of the fact that anthropology can be seen as reinforcing a colonial discourse (Smith, 1999, p.36), and being mindful of these histories and the impact that my research can have on the people I am working with, I felt it important to embrace a collaborative approach for my research.

Collaborative research, however, involves the researcher and the participants working towards a common goal during the research project (Lassiter, 2005, p. 84). Furthermore, in my analysis of the data I use the conceptual method of "restorytelling" as a counter-narrative to the State's representation of Métis. Restorytelling provides a community-centered perspective of the situation of colonialism and their goals of resurgence. It allows the community to retell or restory their histories since these stories have been misrepresented by settler society (Corntassel et al., 2009).

I will retain ownership over all data, however, to ensure a relationship of collaboration and reciprocity, I will be producing reports for each organization based on 
my results. These reports will be based on data I collected during my fieldwork but will address issues and themes that are of upmost importance to each of these groups. I will also share my findings with the communities after the production of the thesis. To ensure my participants will have access to a copy of the research I will send a copy of the final thesis to the three participating organizations as well as the library at Universite SainteAnne, and the resource centre at Unama'ki College at Cape Breton University. ${ }^{3}$

\section{Methodological Considerations and Limitations}

As this is a Master's thesis, there is a substantial surplus of data that did not make it into the text. Although I would have liked to include further perspectives of my participants, I needed to remain mindful of the limitations and the scope of the project. At the time of my fieldwork, Kespu'kwitk Métis Council was in an appeal process in their court case. In lieu of this, they were not able to answer many questions concerning hunting, fishing and gathering. It was best for both parties to omit this information so it would not influence the ongoing trial. Due to this, the ethnographic section "Relationship to Land, Animals and Waters" is not representative of this group. Furthermore, I must note that all Mi'kmaq I spoke with were off-reserve due to the nature of the connections I was able to obtain and events I attended.

Anonymity is not always guaranteed in the snowball sampling/community based research techniques. To minimize this risk, I took all necessary precautions to ensure individuals are not identifiable in the written document. All participants have been assigned pseudonyms. All pseudonyms were chosen by the researcher without input from the participants in order to secure complete anonymity. If there were still identifying

\footnotetext{
${ }^{3}$ As per requested by Mi'kmaw Ethics Watch.
} 
factors after the use of a pseudonym changes to the setting or context were added to increase anonymity further.

The names of organizations will be used, as there are very few and would be easily identifiable. While all measures were taken to protect participant's identity, those in a position of authority (i.e. President, Chief, Elder) or particular experts may still be identifiable due to the nature of their position within an organization and/or community. Participants were able to withdraw from the study up until 3 months after the date of their interview (see appendix D \& C for more on these processes).

In the interest of full disclosure, as a self-identifying Acadian and a Nova Scotian, my identity is intertwined in a portion of the population of this study. As Naraya (1993) articulates, "as anthropologists we do fieldwork whether or not we were raised close to the people who we study. Whatever the methodologies used, the process of doing fieldwork involves getting to know a range of people and listening closely to what they say." Although my own biases and perceptions may influence the way I interpret and write the results of my study, my training in anthropology has provided me with the skills and methodologies to provide an objective view. Although I can be considered an insider in my research project, I was able to gain a degree of access and trust that others may not have been able to gain if they took on this project.

\section{Chapter Summaries}

Chapter 2 provides an ethnohistorical context of the Métis identities in Canada and how the Nova Scotia Métis identities fit into this context. Further, it provides a historical context of the peoples from whom the Métis identities in the province derive: the 
Mi'kmaq, the French settlement/the Acadians as well as the settlement of Cape Sable Island. I explain the legal context of the Métis in Nova Scotia, through an analysis of Provincial and Supreme Court decisions, and how the Métis situate themselves within the category of Métis in Canada.

Chapter 3 provides an ethnographic exploration into the identities of three Métis organizations in Nova Scotia. It explores their historic mixed-blood though four themes that emerged through the analysis of the data: Genealogy and Membership; Language, Relations and Respect; Relationship to Land, Animals and Waters; and Colonialism and Denial. These themes provide linkages between the historic mixed-blood and the contemporary Métis identities as well as the importance of other contemporary relationships, especially with the Aboriginal populations attached to their identities. In addition to exploring Métis identities, there is also a discussion of those Métis who do not belong to organizations, as well as the perceptions of Mi'kmaq and Acadian on the Métis in Nova Scotia.

Chapter 4 provides an analysis of how history, colonialism and the themes presented in the ethnographic material present identities and peoples who fit the category of Métis in Canada. It addresses the "restorytelling" of their histories to combat the colonial discourse of categorization. Furthermore, this chapter critiques the categorization of Aboriginal Peoples in Canada. Métis in Nova Scotia may not have been categorized as Métis, nor was the term dominant in Southwestern Nova Scotia, nevertheless, mixedblooded cultures were cultivated under different names: French, Acadian, and Cape Islander and exhibit considerable similarities to Métis identities across the country. I will also address the way in which the concept of "community" and/or "collective" has been 
taken up in law and by the State to create a variable category of what constitutes Métis and how this creates further challenges for the Métis in Nova Scotia as they continue to attempt meeting these standards.

Lastly, Chapter 5 provides a concluding analysis and summary of the study's main findings. It speaks to the growing interest in Métis recognition in Canada and in the Maritime Provinces and the impact of the Métis identity changes in Canada. Furthermore I address the changes that are occurring in the categorization, recognition and rights of Métis in the country. In addition to this, I provide suggestions for future research in this area. 


\section{Chapter 2: Who are the Métis in Nova Scotia? Building an Ethnohistorical Context}

The aim of this chapter is to elaborate on my research question: Who are the Métis in Nova Scotia? To answer this question fully we first need to look at the historical context, legal context and the Canadian political-legal domain. This chapter provides an overview of the development of historic Métis identities in Canada, the settler history of Nova Scotia and finally a look into the legal and political actions that have an effect on the Métis in Nova Scotia. Lastly, I will explore how the Métis in Nova Scotia are trying to fit into the preconceived categories and criteria that the government has constructed in order to be recognized "officially" as Métis in Canada.

\section{Métis Identities in Canada}

Traditionally, Métis in Canada have been seen as a western Aboriginal identity derived from the métissage and intermarriage that occurred during the Canadian Fur Trade among employees and freedmen of the Hudson's Bay Company, the North West Company and Aboriginal women (Brown, 1980; Rich, 1967; Town 1998). Brown (1980) recounts the relations that company men in the Hudson Bay and the North West Companies had with the Aboriginal women, stating that practically all officers and most lower wage employees, some of whom had wives in Europe, were in relations with native women by 1812.

Métis identities developed though the continuation of these relations and the offspring being raised together in what became Métis communities along fur trade routes placing Métis women at the center of Métis community creation (Reimer \& Chartrand, 
2004; Devine, 2004). Through these partnerships and relationships Aboriginal women were able to establish with European men, they were able to create family unions, relationships of marriage, alliance, and friendships as well as economic and social relationships between the Aboriginal populations and Europeans. These Aboriginal women are ultimately the heart of the Métis ethnogenesis in Canada (Devine, 2004; Van Kirk, 1980; Iseke-Barnes, 2009).

A crucial movement in Métis history and recognition was the emergence of the Red River Colony in Manitoba, where the Métis of the Saskatchewan River fought against the government in 1870 for Métis rights in Canada (Woodcock, 1975; Stanley 1981). Louis Riel and Gabriel Dumont were at the center of this movement as they risked their lives to lead the movement to its success; including the initial settlement, influence of the government, and relations between Métis and the State (Beal \& Macleod, 1984; Weinstein, 2007; Boyden, 2010). The Manitoba Act 1870 established Manitoba as a province of Canada and was largely influenced by the Métis and their title to this land. This ambitious effort to fight for Métis rights and the establishment of Manitoba are central to how all Métis issues are seen in Canada today.

Along with the importance that these efforts played in the recognition of Métis in Canada, many Métis scholars have used history as a main point of exploration (Macdougall, 2006; Devine, 2004; Iseke-Barnes, 2009). Tracing historical ties and genealogy, these scholars have been able to trace relationships including marriage, alliance, friendships between the Aboriginal population and the European workers and settlers. Devine (2004) also explores the mobility of the Métis family through the fur trade as well as genealogical and church records, oral histories, and diaries to trace their 
ethnogenesis. With the ability to trace mixed-blood to the fur trade records and oral histories many Métis in the west and in Ontario have been able to ascertain further degrees of recognition.

There is a strength that resonates in oral histories of Métis, particularly those of Métis women. It is through the continuation of oral traditions and historical document analysis of fur trade endogamy and the role of women within fur trade forts where we find the significance of women's role in the Métis Nation (Campbell, 1982; Reimer \& Chartrand, 2004). Most recently Métis history in Ontario has traced oral traditions, genealogy and shared experiences of this Métis culture to aid in Post-Powley recognition in the province (Reimer \& Chartrand, 2004). In addition, Nova Scotia was not absent from the fur trade, as Faragher (2005: 46), explains:

The "Indian Children" belonged to the interethnic families of the settlement. Most of the engagés [indentured servants] with native wives and Métis children remained in the vicinity of LaHève or Cape Sable, where several small fishing and trading communities developed, but a number relocated to Port Royal. Their presence helped maintain good relations with the Mi'kmaq and introduced colonists to the practice of métissage.

Port Royal was a significant trading post in early Acadia and played a key role in the development of relationships between Mi'kmaq and settlers (Faragher, 2005; Griffiths, 2005).

\section{Métis identities in the Maritime Provinces: The Eastern Doorway}

The Métis identities in the Maritime Provinces are derived from an over 400-year-old settler history. Drawing on this long history, Saul (2008: 8) states, "there is a perfectly straightforward foundation to these four centuries of shaping Canada. Anyone whose 
family arrived before the 1760 s is probably part aboriginal." The Maritimes Provinces of Canada comprise of Nova Scotia, New Brunswick and Prince Edward Island. Nova Scotia has a population of 913,462 , New Brunswick 729, 997 and Prince Edward Island 135, 851 (Statistics Canada, Population Census 2006). All three provinces have populations of Acadians and Mi'kmaq, and in New Brunswick there are significant Maliseet and Passsamaquoddy populations. There are 14,375 self-identifying Acadians in Nova Scotia, 25,400 in New Brunswick and 3,235 in Prince Edward Island (ibid). There are 35,240 people of Aboriginal origins in New Brunswick, 48,210 in Nova Scotia and 3,680 in Prince Edward Island. Of those who are of Aboriginal origins, 385 identified as Métis in PEI, 7,680 in Nova Scotia and 4,270 in New Brunswick.

At the national level Métis are represented by the Métis National Council (MNC), which acknowledges Métis in Ontario, Manitoba, Saskatchewan, Alberta and British Colombia. This national organization, however, does not recognize Métis in the provinces of Québec, Newfoundland and Labrador, Nova Scotia, New Brunswick and Prince Edward Island (MNC, 2012). Since the MNC only acknowledges the aforementioned provinces, and Métis are first required to register through their provincial Métis Nation, the unrecognized provinces are not able to establish membership in the MNC at the national level.

Métissage in Eastern Canada has thus been seen simply as a mixed-blood or mixed-race that did not develop into a Métis identity in any capacity due to the higher quantity and wide dispersal of this mixed-blood population (Lawrence, 2004). However, since the Supreme Court of Canada R. v. Powley decision, there has been a greater acceptance for the recognition of possible Métis identities in all provinces east of Ontario. 
These include: Innu derived Métis in Northern Québec and Labrador; and Mi'kmaq derived Métis in Nova Scotia, New Brunswick and Prince Edward Island. Significantly, these Métis identities east of Ontario have not been fully recognized by the Canadian State.

\section{The Mi'kmaq in Nova Scotia}

The Mi'kmaq first occupied the land of Mi'kma'ki, which includes the Maritime Provinces, Newfoundland and the Gaspé peninsula (See Figure 2). In 1536, Jacques Cartier first made contact in the New World; contact between the Mi'kmaq and colonists' in the Maritimes dates back to as early as 1604 at Port Royal (Plank 2003, Griffiths, 2005). The relationship between the French and the Mi'kmaq was not a hostile one. In fact, the Mi'kmaq considered themselves superior to the French due to the lack of knowledge the French had about the land (Gould \& Semple, 1980). The nature of these early relationships were based on land habitation and founded on understandings of use and occupancy of the land (ibid). The Mi'kmaq also relied on the French for trade goods and weapons, yet in exchange the French relied on the Mi'kmaq for defense against other Europeans (ibid). 


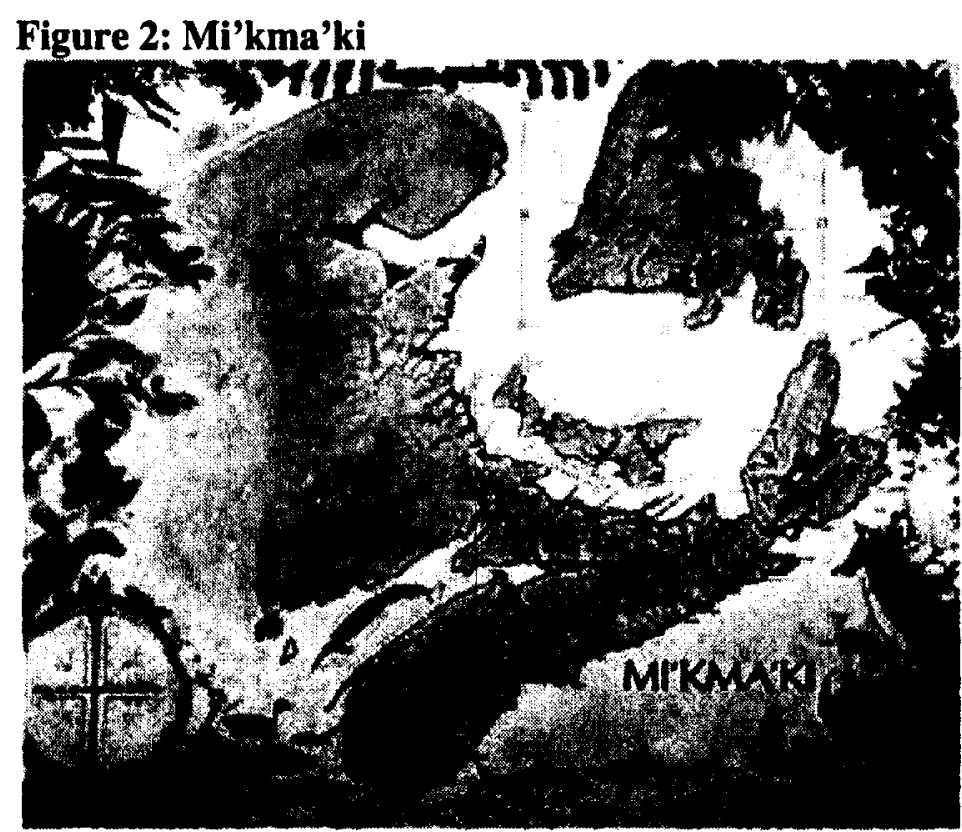

Source: Native Council of Nova Scotia, http://ncns.ca.

Grand Chief Membertou was one of the first Mi'kmaq to make contact with these early explorers. He converted to Catholicism in 1610 after being exposed to French religious practices by missionaries after the establishment of Port Royal (Plank, 2003). Unlike other groups who converted to Catholicism, the Mi'kmaq were able to adapt the religion in line with their own traditional beliefs, such as using sage instead of incense and leaving the language base as Mi'kmaq rather than Latin (Plank, 2003; Paul, 2000). In early colonial struggles, the Mi'kmaq allied themselves with the French. However, in 1713, Acadia, present day mainland Nova Scotia, was placed in British control under the Treaty of Utrecht, resulting in the French, the Acadians and the Mi'kmaq falling under British rule (Griffiths, 2005; Gould \& Semple, 1980; Coates, 2003). Neither Britain nor France seemed concerned about governance allocation after the treaty, which left the English in control of Nova Scotia and the French in control of Île Royale, present day Cape Breton Island (Mancke \& Reid, 2004; Griffiths, 2005). 
After the British established control of Nova Scotia they needed to deal with the two populations they felt caused them a degree of threat: the Mi'kmaq and the Acadians. The Acadians possessed the rights within the Treaty of Utrecht to take a year to decide where their allegiance would lay (Griffiths, 2005; Mancke \& Reid, 2004). However, the Mi'kmaq and the Acadians were encouraged to migrate to île Royale, as it was still in French control (Gould \& Semple, 1980; Mancke \& Reid, 2004). Some Acadians did make the decision to migrate to Ile Royal as it allowed them to retain their own legal status and those who stayed would be subject the British rule. Many Acadians stayed to oppose the British, while the Mi'kmaq were to be dealt with differently, within their collective bands (Plank, 2003).

Peace and Friendship treaties between the British and the Mi'kmaq were signed between 1725 and 1779. These treaties concerned the relations between the Mi'kmaq and the British; however no treaty addressed land cession (Wicken, 2002: 184). Early treaties, signed in 1725, guaranteed the protection of Mi'kmaq from incorporation into English law and the retention of Mi'kmaq sovereignty and protection of Mi'kmaq traditions (Plank, 2003: 83). Treaties signed between 1760 and 1761 pertained to harvesting rights and agreements that the Mi'kmaq would not attack the British and that British laws would take priority over Mi'kmaq law (Plank, 2003; Coates, 2003). According to Mi'kmaq oral traditions, the true purpose of these Peace and Friendship Treaties was to ensure that the British would not interfere with the land of the Mi'kmaq (Coates, 2003; Wicken, 2002).

Today, the Mi'kmaq in Nova Scotia govern themselves in various forms: through representation in the Mi'kmaq Grand Council; participation in the Native 
Council of Nova Scotia; and through locally elected Chiefs and Councils based on the Indian Act. The Native council of Nova Scotia (as the New Brunswick Aboriginal Peoples Council and Native Council of Prince Edward Island, in their corresponding provinces) represents and protects the rights of non-status and off-reserve Indians. The Grand Council is a hereditary, traditional governing structure that includes keptins ${ }^{4}$ from the seven districts of Mi'kma'ki, who represent and protect the rights of Mi'kmaq onreserve. Mi'kmaq legal traditions have been passed on through generations of members of the Grand Council, and its presence remains strong throughout the seven districts or sakaonwati. The sakaonwati form the Grand Council, which meets regularly to deliberate on issues or contentions that arise and work towards solutions (Borrows, 2010).

On August 31, 2010, the Mi'kmaq in Nova Scotia signed an agreement that requires Nova Scotia and Canada to consult with them about activities that will occur on their land. They had been under an umbrella agreement since 2002, which required consultations to determine the degree of recognition and implementation that would occur as based on the "Made-In-Nova-Scotia Process" (MINSP, 2002). Chief Terrance

Paul, of the Assembly of Nova Scotia Mi'kmaq Chief's noted:

Today's signing ceremony represents the commitment of three governmentsFederal, Provincial, and Mi'kmaq - to make things right. We must not forget that this tri-partite relationship is unique in Canada. The entire Nation is looking upon us to show that such cohesion is possible. We must not fail (AANDC, 2010).

\section{French Settlement and the Acadians in Nova Scotia}

Early French settlers and the Mi'kmaq worked together in a peaceful coexisting manner that was based within the idea of mutual respect and responsibility. The good relationship

\footnotetext{
${ }^{4}$ Grand Captain, also known as Kji Keptin
} 
that developed between the French and the Mi'kmaq became the foundation for many cultural exchanges that ranged from agriculture, religion, language and intermarriage between these peoples (Griffiths, 2005; Mancke \& Reid, 2004; Paul, 2000; Faragher, 2005; Ross \& Deveau 1992). The Acadian ethnogenesis comprises various elements: their close relationship with the Mi'kmaq; a unique political structure, comprising a claim to neutrality; and their unique agricultural system that allowed them to live off their new land (Griffiths, 2005). It was a creation of "a people where none had been before" (Griffiths, 2005: xvii).

The relations between the two populations remained close; Saul (2008: 11) states that the Acadians are the only settler population in the country that fully acknowledges that they would not have survived without the aid of an Aboriginal population. There is a consensus among historians that the Mi'kmaq and Acadians worked together and did not interfere with the land that the other wished to inhabit (Griffiths, 2005; Mancke \& Reid, 2004; Paul, 2000; Faragher, 2005). Since many Mi'kmaq had converted to Catholicism along with their Grand Chief, Membertou, early in the settlement of Port Royal, it also created desirable marriage circumstances, as both were Catholic. Ross and Deveau (1992: 12) describe the relationship established with the Mi'kmaq as "the most important accomplishment of Port Royal."

Between 1719 and 1730 there were a number of oaths taken by the Acadians that pertained to their claim to neutrality (Basque, 2004; Griffiths, 1992). The Acadians were frustrated with being marginalized and the British were not prepared for the sophisticated way the Acadians began to resist these oaths (Faragher, 2005). The marginalization of the Acadians by the British ultimately increased their independence as a people and 
strengthened their identity and political structure (Griffiths, 2005). When the British became wary of the Acadians' claim to neutrality based on their good relations with the Mi'kmaq and trade relations with the French they requested that the Acadians declare themselves as British allies. After refusing to declare allegiance to the Crown in 1755 , the British authorities exiled the Acadians from Nova Scotia (Griffiths, 2005; Mancke \& Reid, 2004; Ross \& Deveau, 1992).

Acadians were deported from Nova Scotia in what is referred to as le Grand Dérangement, the Great Upheaval, or simply the Acadian Deportation, which was a process of exile that occurred between 1755 and 1762. Some Acadians and mixed-blood peoples were able to escape deportation as they were classified as Mi'kmaq or taken into hiding by the Mi'kmaq (Surette, 2004; Ross \& Deveau, 1992). The deportation left Acadians dispersed throughout the Maritimes and elsewhere in North America. Many Acadians returned to the Maritimes to establish new communities; resettling in Nova Scotia, New Brunswick and Prince Edward Island but many also remain in the Southern United States, now known as the Cajuns in Louisiana.

Acadians are a proud people coalescing around a shared collective identity as a Francophone population in Canada (Ross \& Deveau, 1992; Caplan, 2004; Hautecoeur, 1976). The Acadians strive for nationalism in similar ways as Québec and celebrate their unique culture and traditions (Handler, 1988; Hautecoeur, 1976). The Acadians have been indirectly affected by the significant changes that took place in Canada in the 1960s in terms of the Federal recognition of the French language (Ross \& Deveau, 1992; Jobb, 2005). The Acadians have a strong will to survive in this changing country and have their own goals in terms of recognition, as Maillet stated at the Acadien Congrès Mondial in 
2004: "As long as there is one living Acadian, Acadie will go on. We were, we are and we will be" (Jobb, 2005: 238).

\section{Cape Sable Island}

Cape Sable Island serves as the southernmost tip of Nova Scotia and is located in Shelbourne County. The settlement of Cape Sable Island began as a French colony and trading post in early Acadia by Charles de la Tour naming it Cap de Sable in 1620, after the initial settlement of Port Royal (MacDonald, 2000; Fischer, 2009). Between 1756 and 1758 the British raided the settlement as they deported the Acadians from Nova Scotia (Pickard Bell, 1990). Many Acadians and Mi'kmaq were able to escape the Island while others were taken prisoner to Halifax (Pickard Bell, 1990). By 1759 all remaining Acadians were removed from Cape Sable Island (Landry, 2007).

English resettled Cape Sable Island in the 1700s after New England troops raided the Island during King Phillips War and again in the 1750s by New England migrants (Pickard Bell, 1990). This war also resulted in Wampanoag from New England migrating to Southwestern Nova Scotia. It was unknown and undetermined how far westward in Nova Scotia was under British claims, which left this part of the province unclaimed between Nova Scotia and Massachusetts (Pickard Bell, 1990: 26). This unclaimed nature of the land was not resolved until October of 1691 , where it was determined that the western portion was indeed Nova Scotia and not Massachusetts (ibid). Pickard Bell (1990) notes that in the years of undetermined claims, it is believed that New Englanders would have continued to travel to this "unsettled" land to set up camps to harvest and fish off the shores. More (1873:10) describes an Aboriginal presence on Cape Sable Island: 
The Cape Sable Indians are often spoken of and seem to have been a numerous tribe, and may have included the Indians of this province and westward of Lahave.

It is speculated that the settlement of Cape Sable Island resulted in the practice of métissage between the English, Wampanoag and the Mi'kmaq that would have already occupied the Island.

\section{The Métis in Nova Scotia 5}

According to Elliot (2005), the Métis "are descendants of mixed marriages between people of Indian or Inuit and European descent. These mixed marriages occurred at European settlements in New France, Acadia, Labrador, the Red River Valley, and elsewhere" (20; emphasis added). However, one of the main problems that arises in the discussion of métissage, mixed-blood or Métis in the Maritimes, or what was once Acadia, is the categorization of these identities. The arguments advocating in favour of a Métis presence in the Maritimes are heavily based within early settler history and therefore create a complication as to where those who identify as Métis fall in the spectrum of the people of the Maritime Provinces. Due to the lack of primary documentation of the Métis, the ethnogenesis of the Acadians has become a key source for demonstrating a formation as a Métis population and identity (Surette, 2004).

It is argued that the Acadian Deportation, or Le Grand Dérangement, resulted in the mixed-blood/Métis communities that would have existed in the region being disrupted alongside the Acadian communities (Tufts, 2009; Surette, 2004). A counter argument to this point is that the Peace and Friendship treaties would have prevented the

\footnotetext{
${ }^{5}$ As the Sou'west Nova Métis Council comes from a history that differs from the French/Acadian history, they have not been addressed in the following studies.
} 
British from disturbing any of mixed-blood who were living in Mi'kmaq communities, as the goal was to solve their Acadian problem, and they did not want to disrupt the peace they had achieved with the Mi'kmaq. ${ }^{6}$ Betty Ann Lavallée, CAP National Chief, described the Acadian deportation as a point of disruption that can limit Powley implementation, as many of mixed-blood would have identified as $\mathrm{Mi}$ 'kmaq in order to escape the deportation and then would have adopted a Mi'kmaq identity. ${ }^{7}$ However, mixed-blooded people who were classified as Acadians would not have been protected and would have resettled into Acadian communities after the deportation, as many families were separated during the exile (Ross \& Deveau 1992: Surette, 2004).

Gould and Semple (1980: 3) explain a colonial situation that is very reflective of early Western fur trade Métis ethnogenesis occurring in the Maritimes. They state:

The struggling French settlements were mainly populated by soldiers, hunters, trappers and missionaries. It was only natural that the two races should mix. The early colonists often married native women out of necessity, thereby creating the first Métis population in what is now Canada.

According to CAP, however, the federal government's efforts to document and discredit a Métis presence in the Maritimes were insufficient. The Powley Implementation Project (2008) notes five main issues: (1) there was a lack of women and children in the records examined by federal government researchers; $(2)$ the documents analyzed were all written from a non-Aboriginal perspective; (3) the documents did not include any oral histories; (4) there were large areas of time and space that were not included in the analysis; and (5) the historical records were being examined though individual perspectives and not through a collective perspective.

\footnotetext{
${ }^{6}$ Personal communication, May 17, 2012.

${ }^{7}$ Personal communication, May 31, 2012.
} 
The inclusion of information about women and children has proven to be crucial in the ethnogenesis of the Métis during the Western fur trade as it was the women who raised the family and kept the aboriginal heritage strong in the development of a Métis communities (Van Kirk, 1980; Iseke-Barnes, 2009). Van Kirk (1980) explores the partnerships and relationships that developed between the Aboriginal peoples and the Europeans; it was the Aboriginal women, their halfbreed daughters and granddaughters who kept the lasting Métis family unions alive. She tells stories of sex, love, marriage, childbearing, all accentuating the importance of Aboriginal women in the development of these unions and the thriving nature of the Métis people and the economic role of women in the fur trade. Therefore, for a documented historical record of Métis development to be absent from the Maritime historical record likely decreases the appearance of Métis ethnogenesis in these provinces.

Around 1974 Métis and non-status Indian groups began to organize in the Maritime Provinces. These groups began to mobilize to bring attention to the existence of Métis in the Maritimes and began to trace lineages to mixed-blood roots (personal communication, May 17, 2012). After the R.v. Sparrow decision in 1990 , there was further Métis mobilization of the locally situated Métis organizations. The Native Council of Nova Scotia continually refused to comment on the Métis in the Maritimes during the consultation process in Southwestern Nova Scotia (CAP PIP 2008). This is likely based on the fact that if accepted in to the Native Council of Nova Scotia, members of these Métis organizations would be entitled to harvesting rights. 
In 1999, the Nova Scotia Métis Confederacy was formed to organize the selfidentifying Métis of the province. This organization consisted of six different Métis councils:

- Yarmouth and District - Yarmouth

- Kespu'kwitk - Yarmouth County

- Sou'west Nova - Shelbourne County

- Annapolis Valley - Annapolis Valley

- Eldawik - Halifax

- We'kopekwitk - Truro

The confederacy consisted of a speaker, deputy speaker, a secretary and treasurer and would meet four times a year with the presidents and head elders of each of the six councils. The Confederacy was also affiliated with the Canadian Métis Council (CMC) resulting in the membership cards carrying a $\mathrm{CMC}$ membership number. Due to disagreements between the councils and an incident of financial corruption, individual councils began to separate from the Confederacy in 2003. The Nova Scotia Métis Confederacy was completely dissolved on January 30,2009 . Currently there remains the Kespu'kwitk Métis Council (KMC), Sou'west Nova Métis Council (SWNMC), of the original six, and the Eastern Woodlands Métis Nation (EWMN), L'Association AcadienMétis Souriquois (AAMS). The Métis organizations are now concentrated in the Southwestern region of Nova Scotia. Table 1 provides an estimate of Métis living in the region, totaling 2,930 . 
Table 1: Métis Presence in Southwestern Nova Scotia

\begin{tabular}{|l|l|l|l|l|l|l|}
\hline Geographic Name & $\begin{array}{l}\text { Total } \\
\text { Population }\end{array}$ & $\begin{array}{l}\text { Aboriginal } \\
\text { Identity } \\
\text { Population }\end{array}$ & $\begin{array}{l}\text { North } \\
\text { American } \\
\text { Indian }\end{array}$ & Métis & Inuit & $\begin{array}{l}\text { Non-Aboriginal } \\
\text { Identity Population }\end{array}$ \\
\hline Argyle, MD, (NS) & 8,600 & 1,280 & 65 & 1,190 & 0 & 7,320 \\
\hline $\begin{array}{l}\text { Barrington, MD, } \\
\text { (NS) }\end{array}$ & 7,300 & 645 & 165 & $\mathbf{4 7 5}$ & 0 & 6,655 \\
\hline Clare, MD (NS) & 8,650 & 560 & 70 & 480 & 0 & 8,090 \\
\hline $\begin{array}{l}\text { Yarmouth, MD } \\
\text { (NS) }\end{array}$ & 10,185 & 900 & 95 & $\mathbf{7 8 5}$ & 0 & 9,290 \\
\hline Total & 34,734 & 3,385 & 395 & $\mathbf{2 , 9 3 0}$ & 0 & 31,355 \\
\hline
\end{tabular}

Source: Aboriginal identity population, for Canada and census subdivisions (municipalities) with 5,000 plus population -20\% sample data, Statistics Canada, 2006 Population Census

The Congress of Aboriginal Peoples, which represents Métis and non-status Indians, acknowledges a Métis presence in the Maritime Provinces. They work in affiliation with the Native Council of Nova Scotia, the New Brunswick Aboriginal Peoples Council and the Native Council of Prince Edward Island, and in tandem with the Maritime Council of Aboriginal Peoples. In a report made by the Native Council of Canada in 1979, it is noted that in Nova Scotia, New Brunswick and Prince Edward Island, there are approximately 10,000 Métis and non-status Indians, in the same report, Gary Gould explains:

Acadians were the first white settlers in New Brunswick and Nova Scotia to come into contact with Indian people. Acadians inter-married with Micmac and Malicite people. Undoubtedly the early history of the Acadian had a strong influence in our history and vice-versa. (Native Council of Canada, 1979: 36)

The "strong influence" that the Acadians had on the Mi'kmaq and Maliseet people and their history has become the foundation of contemporary Métis identity in the Maritimes. It is also interesting to note that the word "Acadie" and thus the word Acadian is derived 
from the Mi'kmaq word for land, and therefore Acadian roughly translates to "the people who live off the land" (Paul, 2000).

In terms of recognition of Métis in the Maritimes, the Report of the Royal Commission on Aboriginal Peoples (1995), presents a category of "Other Métis" which acknowledges a Métis presence in the Maritimes. The Commission describes these communities as having suffered through the Acadian Deportation, yet, enduring and regenerating in both Nova Scotia and New Brunswick thereafter. This document not only notes the lack of constitutional rights and recognition of the Métis in the Maritime Provinces, but also directly categorizes them as Others, in their classification of "Other Métis", thus allowing the classification to be made at the level of the state not within the realm of the community.

\section{The Legal Context for Métis in Nova Scotia}

The political situation for self-identifying Métis in the Maritime Provinces is multifaceted in the various ways the groups are identifying with numerous governmental and legal cases that define what it is to be Métis in Canada. These include: Section 35 of Canadian Constitution Act 1982; R.v. Powley; Daniels v.R; and Manitoba Métis Federation v. Canada. There are also Métis definition problems within Canadian Case Law. These include Métis court cases out of New Brunswick and Nova Scotia: R. v. Vautour, R. $v$. Hopper; R. v. Lavigne; R. v. Chaisson; R. v. Diagle; Castonquay \& Faucher v. R; R.v. Hatfield; and R.v.Babin. The Nova Scotia Métis' inability to effortlessly fit into the Canadian government's criteria has left them in an ongoing struggle in search for recognition as part of the State's official colonial category of Métis. 
Due to these issues, all Métis claims in the Maritime Provinces have been denied in the provincial courts of Nova Scotia and New Brunswick. The courts have consistently determined that there were no Métis communities in the provinces before 1670 , the date of European Control in Canada. These decisions have left the self-identifying Métis in Nova Scotia defined by the state and divided amongst themselves.

\section{The Jay Treaty}

The Jay Treaty was signed between the United States and Great Britain, known as the Treaty of Amity, Commerce and Navigation. This treaty entitled tribes that were along the Canadian-United States border to have free passage rights. In the United States this treaty has been incorporated into Immigration Policy, allowing United States tribes to still have this treaty right. In Canada, this treaty has not been incorporated into Canadian Statutory Law for Canadian First Nations who have affiliated tribes on the US side of the border. Rather, it is dealt with in Common Law under "Aboriginal Rights" doctrine (Nickels, 2001). Furthermore, the Canadian Court has a tendency to undermine the Jay Treaty due to its lack of incorporation in law.

The tenets of the Jay Treaty are relevant to the Sou'west Nova Métis Council; if the Jay Treaty were respected in Canada, members of this Council may have had more knowledge and attachment with their Wampanoag roots. This leaves self-identifying Aboriginal Peoples on Cape Sable Island looking towards identification as Métis. Since this mixed-blood group is comprised of English settler, Mi'kmaq and Wampanoag bloodlines, as they see it, the category of Métis is their only option, in order to be recognized as Aboriginal Peoples in Canada. 
Sou'west Nova Métis Council, also known as the Nova Scotia Wampanoag, also fall into the struggles that other Métis councils face in terms of meeting the Powley Test criteria. However, in the unique aspect that they are also descendents of an American Indian Tribe, they make an argument that Canada not implementing the Jay Treaty and that this is partially responsible for why they are unable to ascertain recognition as Aboriginal Peoples in Canada. Daphne Williamson, a representative of the Sou'west Nova Métis Council during the Standing Senate Committee on Aboriginal Peoples on Métis recognition stated:

Part of the problem is the fact that the Jay treaty, Article III in particular, has never been recognized in Canada...

...Let me see if I can paraphrase Article III of the Jay treaty accurately. It essentially says that the mobility and trade that was carried on by Aboriginal people prior to the creation of the Jay Treaty would go on. There was no implicit or explicit restriction on our rights.

What I am saying is that if I were Iroquois and went into the U.S., or if I were Mi'kmaq and I went into the U.S. to work or to stay, to do whatever I wanted to do, the United States government would respect my rights and acknowledge my rights as a Canadian Aboriginal person. It does not work the same way when American Indians come into Canada. ${ }^{8}$

This approach adds an interesting dimension to the claims that the Sou'west Nova Métis Council are putting forward and raises further questions about what we need to consider when looking at tribes that border the United States and Canada. Of particular interest here is during the early colonization of Nova Scotia, when there was no consensus between Nova Scotia and Massachusetts as to who owned the southwestern region of the province until 1691. This undetermined westward border in Nova Scotia left the area unclaimed between Nova Scotia and Massachusetts, with New Englanders and Wampanoag using the area as a harvesting locale (Pickard Bell, 1990: 26). As a result,

${ }^{8}$ Proceedings of the Standing Senate Committee on Aboriginal People: Issue 26 Evidence - November 6, 2012, Parliament of Canada. 
the Wampanoag very well could have still remained in Nova Scotia when the land was deemed British territory.

\section{R.v. Powley}

R. v. Powley, passed in 2003, has been the instrumental Supreme Court of Canada decision for Métis groups in Ontario, and across Canada, for achieving constitutional recognition of their Aboriginal rights. R. v. Powley states that a person of mixed-blood who belongs to a recognized Métis community can be granted Métis status in Canada under section 35 of the Constitution Act 1982. One of the main outcomes of R.v.Powley is a set of specific instructions relating to the identification of Métis rights, similar to the "integral to the distinct" culture test for First Nation rights outlined in the Supreme Court of Canada's 1996 Van der Peet decision. Ladner \& Dick (2008:71) describe the Van der Peet decision as "a new and regrettable path" that ultimately created a means for cultural justification of Aboriginal rights.

The implementation of the "integral to a distinctive culture" test allowed the court to begin determining Aboriginal rights on a basis of Aboriginal authenticity and constrain scope of Aboriginal rights in s. 35 (Ladner \& Dick, 2008). Based on the Van der Peet model, in order to assert a Métis rights, the Powley Test requires a claimant to ensure that (1) there is a characterization of the right; (2) there is an identifiable historic rightsbearing Métis community; (3) there is an identifiable contemporary rights being Métis community; and (4) one has membership in the contemporary Métis community $(R . v$. Powley, SCC 2003). 
This decision and its proceeding test allow the Métis of Canada to be defined and identified as Aboriginal Peoples by the state. With this top-down approach, there is little flexibility for a Métis group to make a claim, especially when their claims are consequently rooted in a relatively undocumented history. The success of the $R . v$. Powley in Ontario, however, has increased the hope for those searching for recognition in the Maritimes; but these groups continue to remain unsuccessful in their claims.

The Congress of Aboriginal Peoples' Powley Implementation Project sought to document the unrecognized Métis of Canada, including those in Nova Scotia. The project's goal was threefold:

1. To identify CAP Métis constituent communities who can qualify as historic Métis communities within the test of Powley decision of the SCC;

2. To quantify the number of individual rights-bearing Métis harvesters there may be within the membership of CAP affiliates; and

3. To help establish a framework with respective provincial governments for the consultation/negotiation of a practical harvesting regime for rights-bearing Métis harvesters within affiliate constituents. (CAP PIP, 2007).

The major issue with the implementation of the Powley Test in the Maritimes is that there is an inability to prove the existence of a historic Métis community (CAP PIP, 2007). This problem of "community" is a major aspect of the CAP Powley Implementation Project. Lombard (2007: 8) argues that there is an important distinction that must be made between community and collective, and this distinction is not made in R. v. Powley as the terms seem to be seen as interchangeable. The Court refers to community as a "site" or "geographic location" but there is no indication of the size of this "site" or "geographical location" (CAP PIP, 2007: 94). This ambiguous description of community results in many Métis issues being unresolved as it stands it the way of the purpose of s. 35, as Canadian case law does not provide a definition of what constitutes a 
community (O’Toole, 2005: 2-3, 9).

Another problem that arises with the implementation of the Powley Test in the Maritimes is that the region has a 400 -year-old settler history, and is being evaluated in the same terms as Ontario and the West, which have a more recent and more traceable history. There are very few existing primary documents that refer to a Métis population in the Maritimes. This became the focus of Justice Canada's Profile on Mixed EuropeanIndian Ancestry in Southern Nova Scotia (Brown \& Riley, 2005). In this report, government researchers acknowledge the large quantity of mixed-blood in Southwestern Nova Scotia. And, while they are unable to determine a distinct historical community due to the lack of primary sources, they admit that they could not disprove the existence of these communities (ibid). Brown and Riley (2005:1 12) note that the remote location of this population could have removed it from public scrutiny and therefore from documented record.

In 2008, The CAP Powley Implementation Project consulted with the communities in Southwestern Nova Scotia, one in Yarmouth and another in Clare. There was a total turnout of 360 attendees between the two events (CAP PIP, 2008: 23). The Métis in Clare viewed themselves as one group, identifying as Acadian-Métis and the attendees in Yarmouth were from various groups. A concern raised among the group in Clare was that they identified more fully with their Acadian heritage because they were forced to hide their Aboriginal heritage, and have only recently felt safe to express their Aboriginal pride. Concerns that arose in Yarmouth were more political in nature than those in Clare, the most pressing of which was their displeasure in being denied inclusion within the Native Council of Nova Scotia. CAP suggests that the identifying Métis in Southwestern 
Nova Scotia need to build understanding among themselves because they are not strong politically due to the fact that they stand divided on issues. If they were to form an overarching Maritime Métis group, they would likely become a stronger force (ibid: 24).

\section{Daniels v. $\mathbf{R}$}

In 2002, long time Métis rights activist and writer, and past president of the Native Council of Canada, Harry Daniels, now deceased, wanted to see all Métis and Non-Status Indians recognized under the legal category of 'Indian' in the Constitution Act of 1867. The case of Daniels, Gardner \& Congress of Aboriginal Peoples v. Canada comprises of three parts: "(1) to establish that Métis are "Indians" for the purposes of s. 91(24) of the Constitution Act, 1867; (2) that the Crown owes a fiduciary duty to Métis and non-status Indians as Aboriginal Peoples; and (3) that [Métis] have a right to be negotiated with, on a collective basis, in good faith by the Crown" (Teillet, 2011: 87). On January 8, 2013, the federal court ruled that Métis and Non-Status Indians qualify as "Indians" under section 91(24) of the Constitution Act of 1867.

In February 2013, the Harper Government appealed this decision to the Supreme Court of Canada. Former Aboriginal Affairs Minister John Duncan stated:

Given that the Federal Court decision raises complex legal issues, it is prudent for Canada to obtain a decision form a higher consideration of the decision, Canada has filed an appeal, and it would be inappropriate to comment further as the case is before the courts. (The Canadian Press, February 6, 2013).

This Case has huge implications for the way Aboriginal peoples are recognized in Canada. This case is arguing that Métis of the Métis Settlements in Alberta should be recognized as Indians under the $s .91(24)$ of the Constitution Act of 1867. These two cases could be the largest shift in Métis recognition since R. v. Powley. 


\section{Manitoba Métis Federation v. Canada}

In 1981 the Manitoba Métis Federation and the Native Council of Canada filed a 'land claim' that was a series of declarations referring to the Métis as "unjustly deprived of land that they had rights to under the Manitoba Act 1870" (Teillet, 2011: 41). As of 2003, the Native Council of Canada was no longer part of the case. The Manitoba Métis Federation argued that the Crown had an obligation to the Métis because, as Teillet (2011: 41) notes:

(1) Land grants were not made promptly and were not grouped according to family;

(2) Children received land grants before gaining their majority and those lands were not protected from speculators; and

(3) Canada stood "idly by" while Manitoba passed various legislation that was unconstitutional which enabled and facilitated the sale of the children's grants.

In February 2013, the Supreme Court of Canada ruled in the case of the Manitoba Métis

Federation v. Canada granting the Manitoba Métis 1.4 million acres of land, widely known as the Red River Settlement. This decision recognizes that Métis like all other status Indians in Canada have the rights to make claims on their historic lands and the Duty of the Crown to honor these historic rights.

\section{Fitting Into the Legal Context: Challenges and Opportunities}

There have been a number of provincial court cases where Métis from locally situated organizations have attempted to make cases for the Métis rights in the Maritime Provinces. In November of 1999 , for example, Richard Hopper was found guilty of possessing a deer carcass without a license (Teillet, 2011). In 2008, using the R. $v$. 
Powley as a basis, the New Brunswick Court decided that there was no evidence of a Métis community in New Brunswick. The judge rejected Hopper's identification as Métis and his lineage to Aboriginal ancestors, despite his presenting of genealogical material $(R$. v. Hopper, NBCA 2008). The judge also stated that if others made a case like Hopper, most Acadians would be able to gain Métis status. (Teillet, 2011). The judge argued further that:

The defendant failed to meet the burden of proof required of him of establishing that his ancestors belonged to a distinctive community of aboriginals or Métis, who over the years have continuously lived as distinctive people with their distinctive customs, traditions or way of life (R. v. Hopper, NBCA 2008).

The above case demonstrates the difficulty of determining a historical community and the possible repercussions that a decision like this would have on the state, as if Métis recognition were to be granted in the Maritimes, it would involve a redefinition the way Métis are seen in Canada.

In 2001, Jackie Vautour and his son Roy Vautour, of the East-West Métis Union, were charged with unlawful fishing in a national park in New Brunswick and claimed to be part of the "Mic Mac Métis" with no documentation (R.v. Vautour, N.B.J 2001). In 2010 , prepared with documentation, the Vautours were unsuccessful in their claims as Métis as the Judge Arseneault ruled that there was an overreliance on genealogical information (Teillet, 2011). The New Brunswick Court once again denied the very existence of a historic Métis community in New Brunswick, this time, establishing it as prior to 1670 , the date European of control in Canada (ibid).

A similar decision was reached in Nova Scotia Provincial Court in December 2011, as Babin, of the Kespu'kwitk Métis Council, was unsuccessful in his claim, the 
judge also establishing 1670 as the date of control in Nova Scotia. The judge advised the Kespu'kwitk Métis Council that, "there was no Métis Community in the area prior to Effective European Control," the Kespu'kwitk Métis Council has decided to appeal this decision.

In Castonguay and Faucher v. R., the judge asserted that Métis in the East are creating communities in order to gain rights (CAP PIP, 2007:51):

The defendants established a so called "Métis" associations for the purpose of claiming their rights as Métis. In my opinion, such a claim cannot be made out merely by creating an association and relying on an ancestral connection that is then ten or more generations old. The aboriginal right in issue is protected and recognized by the Constitution of Canada. Such rights are not acquired so easily.

This is an interesting analysis, as it is implying that all Métis organizations in the Maritimes are in pursuit of rights that they do not truly deserve as they question the authenticity of their Aboriginal identities. It is this outlook on the part of the Court that is making the Powley Test almost impossible to use in the Maritimes. Interestingly, as they continue to deny the existence of Métis in the Maritimes, the Nova Scotia Provincial Court swore in a Judge who was deemed Nova Scotia's first Métis judge in 2009.

Considering these cases in relation to history and in application of Powley Test, it seems as though there is a disconnect as to why the cases were deemed to have no Métis presence in New Brunswick and Nova Scotia. The cases rely heavily on history and genealogy, aspects expected in the Powley Test. While the court is placing the emphasis on an overreliance on genealogical information, this is exactly the information that is needed in the test itself to prove the existence of Métis in the Maritimes.

In 2005, Lavigne was charged for unlawfully hunting of game in Gloucester county of New Brunswick (R.v. Lavigne, [2005] N.B.J.No.92). Although there are 
aspects of his case that refer to Mi'kmaq relations with the Acadians and mixed-blood, the defendant did not present his case as "Métis" but rather in pursuit of proving Mi'kmaq heritage. Due to the manner in which the case was presented, the judge was not able to use the Powley Test and Lavigne was recognized as Aboriginal under s. 35 of the Constitution Act, 1982 (ibid). Identifying as Mi'kmaq has been proven to have a more successful outcome for many within the New Brunswick Congress of Aboriginal Peoples to gain Aboriginal status than identifying as Métis. ${ }^{9}$

Another overarching problem is the contested nature of the Métis in the Maritimes, especially in the cases noted above. There is no question that there is evidence of historic mixed-blood, but there are many arguments against a distinct community. Daniel Paul (2005), a Mi'kmaq historian and elder, who writes about the Mi'kmaq and Acadian relations and their known friendship, stated that he does not believe that there is a Métis population in the Maritimes. He believes that those of mixed-blood would have been raised in one culture or the other, calling those who contemporarily identify as Métis in the Maritimes opportunists (ibid).

The main problem that arises in terms of the recognition of Métis in the Maritime Provinces is the difficulty that the Métis have in establishing a collective or a community. This coincides with the court ruling that Métis in the Maritimes are depending too heavily on their genealogical evidence, as Teillet (2011) states:

An individual in Canada who can demonstrate any aboriginal ancestry can selfidentify as Métis and, in the absence of other reliable processes, self-identification as Métis may be sufficient for access to some programs and services and

\footnotetext{
${ }^{9}$ Personal communication, May 31, 2012.
} 
educational facilities. However, mere self-identification is not sufficient for the purposes of claiming s. 35 constitutional rights. This is because the recognition and affirmation of aboriginal rights under s. 35 of the Constitution Act, 1982 is reserved for collectives - the "aboriginal peoples of Canada". This means that while an individual may self-identify as Métis, unless he or she can also prove to be a member of a Métis rights-bearing collective, such an individual will not likely be able to claim s. 35 protection (p. 12).

Self-identification is not concurrent to constitutional rights. It is evident that there are contemporary self-identifying Métis groups in New Brunswick and Nova Scotia, however the question remains to be placed in their ability to demonstrate collectivity in the form of a community historically and contemporarily.

Although the case of Delgamuukw versus the Queen falls into a different context to those of the Maritime Métis, there are similarities worthy of note. When the Gitksan and Wet'suwet'en placed claim to their territory, a territory where mere Crown occupation would not qualify for extinguishment according to law, Judge McEachern denied the very existence of the people as a civilization before European contact as well as denying the existence of their legal and political traditions (Roth, 2002).

Judge McEachern dismissed the ownership of land to "nothing more than the right to use the land for Aboriginal purposes," also adding, "I am quite unable to say that there was much in the way of pre-contact social organization among the Gitksan or Wet'suwet'en." (R. v. Delgamuukw SCC 1997; Roth, 2002, p. 147). It is this neglect to recognize the historical component of a case that escalates the problem of recognition. The fact that Judge McEachern was able to dismiss this claim based on his assumption that there was no civilization before European contact allows the power to remain in the hands of the state. Parallels can be drawn between the Maritime Métis and Delgamuukw cases in terms of the judge determining the existence of a distinct culture. Reminiscent of 
Judge McEachern's decision that there was no Gitksan or Wet'suwet'en civilization prior to European arrival, Judges in the Maritimes made the decision that there was not a Métis community in New Brunswick or Nova Scotia prior to the date of control.

The Sou'west Nova Métis Council, as they have a history of their own, do not fit into the French settler-Indigenous situation addressed in the aforementioned court cases. In actuality, the Justice Canada reports and the CAP Powley Implementation Project do not mention, the Sou'west Nova Métis Council. They were not consulted with nor were they even brought into the discussion. This is something that one of my interviewees from this organization was very frustrated about as the reports were supposed to be inclusive of the Métis in Nova Scotia.

The Sou'west Nova Métis Council were involved in a court case, $R$. v. Hatfield, in pursuit of recognition of their rights as Aboriginal Peoples. Daphne Williamson, past lawyer of the defendant, stated during the Standing Senate Committee on Aboriginal Peoples on Métis recognition on November 6, 2012, on behalf of the council:

We had our own lawsuit. I litigated on behalf of the community about four years ago. The primary defendant went off on his own little road show and I do not represent him anymore. I represent the community. I do not think his particular case will have any bearing on the community because he does not have representation, he does not have the evidence that we have gathered over the last four years - he does not have anything. That does not affect us at all. ${ }^{10}$

Additionally, the council announced on their website:

It is understood that the Harvesting Court Case will resume this summer. Due to a conflict with participants over the trial strategy, managing control and costs, SWNMC is no longer in a position to participate directly in the court case. ${ }^{11}$

\footnotetext{
${ }^{10}$ Proceedings of the Standing Senate Committee on Aboriginal People: Issue 26 Evidence - November 6, 2012, Parliament of Canada.

11 Proceedings of the Standing Senate Committee on Aboriginal People: Issue 26 Evidence - November 6, 2012, Parliament of Canada.
} 
L'Association des Acadien-Métis Souriquois does not stem from the original six groups in the Nova Scotia Métis confederacy and was founded in 2007. This organization has less membership than the other groups, however, they are steadily growing. Moreover, they are not involved, nor have they been involved in any legal pursuits to date.

\section{Conclusions}

The political environment surrounding Métis in the Maritimes increases the complications in defining their Aboriginal identity. Even though members of the Kespu'kwitk Métis Council and l'Association des Acadien-Métis Souriquois stem from the same historic bloodlines, they have different interpretations of how they should be recognized as Métis. The Kespu'kwitk Métis maintain that they are distinctly Métis, which they see as different from being Acadian, while the Acadian-Métis Souriquois maintain that the Acadian population is the Métis population. On the other hand, the Sou'west Nova Métis see Métis as the only avenue for their unique political situation in Canada, as they derive from American Indians. It is significant that each stance is in effort to meet Powley Test criteria and Canadian Case Law definitions to gain recognition.

Both R.v. Powley and Canadian Case Law place an emphasis on a distinctive geographic area as being essential to gain Métis status in Canada. R.v. Powley places this emphasis on "community" and the court on a "site". The differentiation between site and community became evident in my conversations with the organizations, as Kespu'kwitk Métis Council were focused on the site-specific geographic location and the court and l'Association des Acadien-Métis Souriquois were more concerned with community and culture. Where the Sou'west Nova Métis possess a geographic location that is subject to meet this criteria, Cape Sable Island itself. 
The deeply intertwined histories that I have discussed in this chapter present problems for these groups being recognized as collective Métis by the Canadian state. Without Jay Treaty recognition, there is little way for the Métis of Cape Sable Island to make any other claim to Aboriginality in Canada. Furthermore, with the possible implications of Daniels $v . R$. in the hands of the Supreme Court, we could see even more changes in the Maritimes that this study is unable to explore. As covered in the analysis above, the Powley Test implementation in the Maritimes has proved, again and again, to be unsuccessful for self-identifying Métis in Nova Scotia. However, what will become evident in the following chapters is that Métis continue to strive for this recognition as Aboriginal Peoples because they have a pride in their heritage and Aboriginal roots. In the following chapter, I will examine my ethnographic data to demonstrate, despite their differing political approaches to recognition and incapacity to prove a "site" or "community" to the provincial courts, the Métis in Nova Scotia do share common struggles from the colonization of Nova Scotia and exhibit attributes of Métis cultures. 


\section{Chapter 3: An Ethnographic Study of Métis Identities in Nova Scotia}

In this chapter I examine my ethnographic data to explore the possibilities of Métis identities in Nova Scotia. In the following sections I contextualize Métis identities into four themes that became dominant throughout my fieldwork and data analysis:

Genealogy and Membership; Language, Relations and Respect; Relationship to Land, Animals and Waters; and Colonialism and Denial. These themes highlight the intricate oral histories of métissage through bloodlines; common language; hunting, fishing and gathering practices; and strategies of denial. I argue that these themes and their significance to Métis in Nova Scotia provide linkages between the historic mixed-blood and the contemporary Métis identities. They also highlight the importance of other contemporary relationships the Métis hold with the Mi'kmaq, the Wampanoag and the Acadians.

"Plane un aige"

My first night in the field I attended a concert by Grand Dérangement, a local Acadian group from Southwestern Nova Scotia. At first I thought I was merely going to hear some Acadian music, not thinking that it would have any real relation to my study. Then, before they began singing a song titled, plane un aige, the lead singer said:

On parle trop peu souvent de l'amitié qui a existé entre la nation Mi'kmaq et le peuple Acadien pendant le $17 \mathrm{e}$ et le $18 \mathrm{e}$ siècles. Sans cette entente, il est fort probable que le peuple Acadien aurait succombé aux misères de son passé.

With this acknowledgment of the importance of the relationship the two populations shared I realized the contemporary significance of my project in relation to these 
identities. Growing up in Nova Scotia I have always been aware of the diversity that exists within a relatively concentrated geographic area, but as the group sang plane un aige, which spoke so elegantly of the struggles the Acadians and the Mi'kmaq shared, the importance of land, waters and animals, courage, wars and glory, and the mixed-blooded interwoven histories that created Métis identities came further into view.

Over the course of my fieldwork I wondered how I would contextualize the three organizations I was working with—-the Kespu'kwitk Métis Council, l'Association des Acadien-Métis Souriquois and the Sou'west Nova Métis Council— into one piece of work. The organizations themselves also had similar concerns with my project in terms of how I would adequately address each of their organizations and their identities. However, despite the differences in the three organizations' political approaches to recognition from the government as distinct "communities" or "collectives", the Métis in Nova Scotia exhibit attributes of Métis cultures. These Métis cultures are distinguishable through genealogy, language, and their relationships to land, animals and waters. In addition, all three Métis groups have faced immeasurable struggles regarding colonization in early Nova Scotia, a process that has shaped their identities immensely. As I impart my ethnographic story, the impact of colonization is a common thread that weaves through all aspects of culture, identity, language and current struggles for recognition within the colonial structure that is the Canadian State.

\section{Genealogy and Membership}

In this section, I address how genealogy and membership provide the Métis with evidence of their métissage along with a sense of belonging. I also explore the 
importance of self-determination to Métis identification and to how other groups feel about the presence of Métis in Nova Scotia.

Lawrence (2004:1) notes the important role of both "racial purity" and certain primordial aspects of identity such as "language, ways of living, and cultural knowledge as manifested by distinct beliefs, traits, and practices, transmitted in relatively unbroken lines from a distant past" in memberships to tribal groups. The Kespu'kwitk Métis Council, l'Association des Acadien-Métis Souriquois and Sou'west Nova Métis Council each have a membership process; each applicant must go through this process before obtaining membership in the given organization and their individual recognition as Métis through this affiliation. This process requires members to prove a genealogical attachment to an Aboriginal ancestor. And while each organization has a process by which they legitimize ancestors, these methods were not fully disclosed to me.

Genealogy centers in the region serve as the main resources for tracing Métis genealogies, and the organizations will trace genealogies for applicants. L'Association des Acadien-Métis Souriquois have a partnership with le Centre Acadien at Université Sainte Anne, which approves all genealogy applications for the organization. Kespu'kwitk Métis Council works with a professional genealogist based in Ontario to confirm the genealogy of their applicants. And the Sou'west Nova Métis Council requires all submitted genealogies to be certified by a Genealogical Records Searcher (GRS) or a Certified Genealogist (CG). All organizations retain members outside of Southwestern Nova Scotia. These memberships are primarily in other parts of the province, however, the organizations also have membership elsewhere in Canada and in the United States. 


\section{Genealogy and Métissage}

Quinan, a village in the county of Argyle, presents a unique case of métissage in and of itself. It became a theme within my interview data from both the Kespu'kwitk Métis Council and l'Association des Acadien-Métis Souriquois. It is well known in the area that this community has a higher quantity of mixed-blood than the others, and a large proportion of my participants from the French/Acadian descending lines asserted that, Quinan is very Métis. It is said that Quinan had four 'known Indian tribes': Crow, Black, Partridge and Bison. These four tribes would have intermarried with Acadians. The tribe that was mentioned more often in my interviews was "Black" or "Les Petit Noirs." Quinan also served as an area of community harvesting, hunting and gathering, which will be expanded upon in the following section, and could have increased the degree of métissage practice in the area.

Studies that address the question of Métis in the Maritimes ${ }^{12}$ (Brown \& Riley, 2005; Lombard, 2007, CAP PIP, Augustine, 2008) pay considerable attention to the genealogy of the Acadians. There is no doubt that there is documented proof of intermarriage and mixed-blood in early Acadia. It is documented that Charles de La Tour, Governor of Acadia, married a Mi'kmaq woman between 1626 and 1628 (Surette, 2004). Other documented mixed-blood exists in the Saint-Castin, Petipas, Guédry and Mius bloodlines (Surette, 2004; Brown \& Riley, 2005). Each time I entered a genealogy center or archive looking for information on Métis in the province I was given files on the Miusd'Entremont family.

\footnotetext{
${ }^{12}$ These studies did not address the Métis on Cape Sable Island.
} 
The Muis or Mius-d'Entremont bloodline is of particular interest in the Southwestern region of Nova Scotia. It is well documented that Philippe Mius d'Entremont, was included in the Mi'kmaq census of Acadie in 1708 due to his marriage to a Mi'kmaq woman (Ross \& Deveau, 1992; Jonah, 2010). This bloodline remains strongly tied to the self-identifying Métis in Nova Scotia. However, decedents of this bloodline have the name Muise or d'Entremont; "all Muises are Muises and all d'Entremonts are Muises" (Surette, 2004: 41). The name Muise was used in cases of mixed-blood and those who wished to conceal their "impurities" took the name d'Entremont (ibid).

The Sou'west Nova Métis' bloodlines have similar significance to those of the Acadian lines. Daphne Williamson, on behalf of the Sou'west Nova Métis Council explained in the Standing Senate Committee on Aboriginal Peoples on Métis recognition:

As I stated earlier, our bloodlines have been maintained over many generations. Although I offer to provide my personal genealogy, I can tell you that my genealogy, especially prior to the first settlers of [Cape Sable Island], is almost exactly identical to everyone else from the community. When you compare my genealogy from that point forward to me with everyone else's, you will see the same people and family names over and over again. Our bloodlines have remained very much clear or pure or whatever you want to call it. Everyone on the island knows everyone on the island. When we go to Massachusetts, they say, "Who are you?" I have to say, "I am Daphne, daughter of Belinda," and I have to go way back to Iyannough. I have to know that before they will even talk to me. ${ }^{13}$

The key difference between the French/Acadian derived bloodlines and the Cape Sable Island bloodlines is that the French/Acadian lines are being traced back to

${ }^{13}$ Proceedings of the Standing Senate Committee on Aboriginal People: Issue 26 Evidence - November 6, 2012, Parliament of Canada. 
Mi'kmaq ancestors; and the Cape Sable Island bloodlines are being traced back to the Wampanoag. However, the similarity they share is the 400 -year-old settler history in Nova Scotia and tracing these bloodlines is not always easy in that respect. Although the genealogy is present, the determination of a community creates further difficulty, as Dr.

Arthur Ray described this problem in R. v. Powley (1998:14):

Métis people tend to be invisible or unidentifiable in official records and in other primary sources upon which historians rely to construct the history of Aboriginal groups in Canada. As such, it is very difficult to provide a continuous, well-documented and authoritative history of their communities.

Lawrence (2004) speaks of the role that "blood memory" plays regardless of the diasporic nature that can overwhelm Aboriginal Peoples relationship to their identities. There is a longstanding question of what this blood means to the identities of many Acadians who possess the Aboriginal bloodlines. Sturm (2002:1) in her opening chapter of her book Blood Politics: Race, culture, and identity in the Cherokee Nation of Oklahoma includes this dialogue:

"Does that mean we're Indian?" the grandson wants to know. "By blood," Otis says, "but blood is what you make if it."

This dialogue between Otis and his grandson speaks to the experiences of the Métis in Nova Scotia concerning membership and the disengagement their families experienced in regard to their attachment to Aboriginal bloodlines. One participant, Gary, a member of l'Association des Acadien-Métis Souriquois, stated, "Well I may have a [Métis membership] card that says I'm Métis, but that doesn't mean that the guy down the road 
who doesn't have a card doesn't have the same blood in him that I do!"14 Here, Gary is elaborating on the quantity of mixed-blood that exists in Southwestern Nova Scotia and how many individuals who have this mixed-blood in the region continue to deny any attachment to these bloodlines.

Self-identification becomes a significant part of being Métis in Nova Scotia. Possessing membership in a Métis organization serves as some type of admittance that you are part of this history and that you are proud of the historic mixed-blood. Gary elaborated further in relation to how the Mi'kmaq perceive their movement: "I just don't understand why they are so against us, why they think we're trying to steal their rights from them. All I'm trying to do is be proud of the fact that I have their blood running through my veins." 15 There is a colonial history that has influenced the perceptions and memory of their history with the Aboriginal populations and self-identification will be a key aspect in defining who are Métis in the Maritimes.

\section{Something was missing...}

Many participants described their Métis identification as either something they had always known to something that made everything fall into place when it become known to them. It provided them with a great sense of belonging and an explanation for things about themselves that they have never been able to put into context. Gaining membership provided these participants with recognition of something that they have always been told to ignore or deny, and now they could be proud. Having a voice in this type of political

\footnotetext{
${ }^{14}$ Participant Interview, September 16, 2012.

${ }^{15}$ Participant Interview, September 16, 2012.
} 
association can allow individuals to achieve an increased sense of belonging and to generate solidarity through continued negotiation and discussion (Tully, 2008:164).

Many Métis in Nova Scotia, however, did not grow up identifying with the word Métis. When they came to know of their mixed-blood heritage, they described it as explaining a lot in their lives or as fitting into how they had already lived. This reaction was reflective of what I was learning about the participants in this study and how many of them lived off the land and had a connection with the land and animals that surrounded them. Eleanor, a member of l'Association des Acadien-Métis Souriquois, said she began identifying publically as Métis as soon as she found out: "I was completely happy with it. I just felt like it fit in so well with who I was already, that, and I've always had an interest in the culture of the Mi'kmaq. I was just so happy!"16

This process of rediscovering Métis identities can be seen in terms of both individual and collective ethnic renewal. Nagel (1995: 948) describes individual ethnic renewal as occurring "when an individual acquires or asserts a new ethnic identity by reclaiming a discarded identity, replacing or amending an identity in an existing ethnic repertoire, or filling a personal ethnic void." In addition, Nagel (1995: 948) describes collective ethnic renewal as involving "the reconstruction of an ethnic community by current or new community members who build or rebuild institutions, culture, history, and traditions." Both of these processes are present among the Métis identities in Nova Scotia and the various ways they have been able to rebuild their histories.

${ }^{16}$ Participant Interview, July 26, 2012. 
Corntassel, Chaw-win-is and T'lakwaszi (2009) explore the concepts of "restorytelling" and "truth-telling" as a means of talking about the colonial past and using it to work towards reconciliation. As Corntassel et al. (2009: 144) elaborate:

Indigenous peoples acting together in this way by linking political action and cultural teachings begin to draw the focus back to community and family processes of restorying justice and history, as a mean to challenge the colonial relationship within Canada.

This process allows the indigenous group to restory their histories from the histories of the dominant society. This process of truth-telling is seen through a community centered voice and presents itself as a counter narrative to dominant colonial histories that misrepresent Aboriginal Peoples.

In Nagel's (1995: 951) study it was noted that from the 1970 to the 1980 census in the United States, the American Indian population increased from 792,730 to $1,364,033$. This change was due to an increase in ethnic politics present in the civil rights movement. Furthermore, it created an increased consciousness, ethnic pride and mobilization among American Indians (Nagel 1995: 948). Similarly to Nagel's (1995) study, the Métis in Nova Scotia have been able to mobilize with the growing acceptance of Métis identities in Canada. This process will likely increase rather than dissipate with the increased political interest in Métis recognition though Daniels $v . R$, the Manitoba Métis Federation v. Canada and the Standing Senate Committee on Aboriginal Peoples report on Métis recognition in Canada.

Individual ethnic renewal would involve individuals passing as non-Indian in census categories before re-identifying as Indian in a later census (Nagel, 1995). The "resurgence of ethnic pride meant not only redefining the worth and meaning of their 
ancestry, but also involved laying a new claim to that ancestry by switching their race on the census form from non-Indian to Indian" (Nagel 1995: 957). Likewise, the Métis in Nova Scotia were able to possess this new strength in their ability to practice selfdetermination and possess an acceptance within a community that had not previously been available to them. As Tully (1995) explains:

The sense of belonging and allegiance comes not only from the public recognition of one's culture, but also because one's culture is respected among others and woven into the public fabric of the association, gaining strength and splendour from its accommodation among, and interrelations with, the others. This is more than a civic awareness that citizens of other cultures exist in one's polity. One's own identity as a citizen is inseparable from the shared history with other citizens who are irreducibly different; whose cultures have interacted with and enriched one's own and made their mark on the basic institutions of society (p. 205).

This new found ethnic renewal and self-determination placed the choice of how Aboriginal identities are evaluated back into the hands of the Métis rather than that of the state. This allows the authenticity of their Aboriginal identity to be evaluated by the Métis rather than this history being interpreted and negotiated by others (Clifford, 1988; as cited in Lawrence 2004: 6).

Many participants described a feeling of not belonging before they began their ethnic renewal as Métis or discovery of their Aboriginal roots. The Mi'kmaq-Acadian Festival provided me with an opportunity to meet individuals from New England and Louisiana who had rediscovered their ancestry in Nova Scotia and their attachment to Mi'kmaq, Acadian and Métis identities. Sharon described her experience: "I spent many years researching my genealogy and eventually traced it to my Acadian and Mi'kmaq ancestors."17 Her research led her to visiting Nova Scotia and she was "welcomed home"

${ }^{17}$ Participant Interview, August 18, 2012. 
at the Mi'kmaq-Acadian Festival and was able to connect with others who shared in her heritage and experience of rediscovery.

In some cases, there was less choice to identifying with one's Aboriginal roots. Many mixed-blooded individuals who have light skin can easily pass as European, however, those with darker skin have less choice in denying their Aboriginal identity (Lawrence, 2004). Marie Rundguist, a researcher herself, has been studying her own genealogy and DNA in an attempt to make clear a feeling of not belonging that she had never been able to explain. She grew up in New England being told that her family was French, direct from France and was taught to live to that standard. She knew something in her heritage was unknown since she didn't feel exclusively French and she didn't look French. ${ }^{18}$ In her research she found out that her family was one of the many deported from Nova Scotia in the expulsion of the Acadians in the $17^{\text {th }}$ century, and furthermore that she could have Aboriginal roots (Rundquist, 2012a; Rundquist, 2012b).

Marie's studies, along with providing her with a sense of belonging, have been one of the most significant dimensions to the genealogy and membership of the AcadienMétis Souriquois. Rundguist (2012c) has conducted a DNA study that tests people from New England and Nova Scotia for the C3b Y DNA haplogroup, an Amerindian identifier. Many of these tests have traced back to Germain Doucet, who lived in Nova Scotia in 1641 and was an early settler of Port Royal. This study has been able to validate much of the genealogical evidence that the Métis organizations have gathered through their membership.

\footnotetext{
${ }^{18}$ Personal communication, August 18, 2012.
} 


\section{What's in it for me?}

Many participants were transparent in interviews stating that the, "what's in it for me?" incentive was part of why they first sought membership with a Métis organization. This incentive encompassed the possibly of rights and benefits, particularly hunting, fishing and harvesting rights associated with becoming a member of a Métis organization. However, once they joined and realized what the organizations have to offer, they changed their perspective and grew to have a sense of pride for their heritage that had not previously been in their lives.

One participant approximated, about half of the people who approach the Métis organization, are asking themselves, "What's in it for me?", while the other half are seeking knowledge about their heritage or validation of the identify that their family had denied, and answers to their questions. Some come with the hope that the Métis have rights, others with the hope that they can get a free hunting license but, in reality, they end up with a lot of information about their family's past and an understanding of the impacts that colonial Nova Scotia had on their ancestors.

There is an additional incentive for younger Métis to register with an organization. This is because there is a degree of recognition for individual Métis in the Maritimes though means of self-determination. This means that Métis in the Nova Scotia that are members of l'Association des Acadien-Métis Souriquois, Kespu'kwitk Métis Council or Sou'west Nova Métis Council are eligible for funding as Aboriginal Peoples from the government as these organizations are listed under the Government of Canada's Aboriginal Canada Portal website as issuers of Métis cards. 
Although this has become a reason why many younger Métis are registering, there are some who aren't registering for the perks, as one participant, April articulated:

I did it because I kind of, I just wanted to have it. Like, I just got it this year because I was like I want to get it done. I was already in my program, in university, I just did it, I was like "Mum, I'd like to get my Métis card." And she was like "I want to get it too." And we both, and my sisters got it. If I would have got it last year it would have helped me get in my program but I'm already in my program, it's just something I wanted to have. I wouldn't say it was for the perks. I was already in the program already studying. ${ }^{19}$

This further demonstrates the sense of belonging that the Métis organizations are able to provide to younger generations in the province.

\section{The Acadian Perspective}

The Acadian Perspective is a difficult perspective to describe, as many Métis in the l'Association des Acadien-Métis Souriquois and the Kespu'kwitk Métis Council would have been raised in Acadian families. A major issue that self-identifying Acadians have with the Métis movement is that it has the potential to change the way Acadians perceive themselves, their history and their culture. As Eleanor explains her view:

So we've been doing all of these things that are obviously from the culture of the Mi'kmaq but we've been calling ourselves Acadians because of that background, and that's what other people called us. I don't think there's nothing wrong with calling ourselves Acadians, but the fact is we were Métis people who called themselves Acadian. It true that we do have the French background, but there's as much of the Métis background also. To associate myself, you can't really separate the two. ${ }^{20}$

In terms of the Acadian case of métissage, there seems to be a certain degree of acknowledgment that the Mi'kmaq "helped" the Acadians/French settlers early on in colonization. As one participant described an Acadian uncompromisingly saying to her

${ }^{19}$ Participant Interview, August 9, 2012.

${ }^{20}$ Participant Interview, August 26, 2012. 
one day, "They helped us for the first winter. That was all." Of course there is a degree of variation in the knowledge of the shared history these peoples share, but I was pleasantly surprised with its representation in Acadian museums and historic sites I visited over the course of my fieldwork.

For example, as you enter Le Musée Acadien, at Rendez-vous-à-la-Baie, in Clare, you are first faced with a mural image of Mi'kmaq peoples. This section of the exhibit is titled "Our Mi'kmaq Relations" ("Notre parenté mi'kmaq"). It explains the relations of cohabitation that existed in the early days of French settlement and the manner in which they shared food, hunting and harvesting practices elaborating on how the Mi'kmaq traditional ecological knowledge became part of the Acadian way of life.

The interpretation centre at Grand-Pré National Historic Site also dedicated a smaller section of their exhibit to the influence the Mi'kmaq had on the Acadians. They, much like Rendez-vous-à-la-Baie, noted the survival techniques Acadians learned from the Mi'kmaq early in history. There were pictures side by side, one of Mi'kmaq women curing and drying fish and the other Acadian women practicing the same techniques. All sites and museums I visited touched on this relationship at least minimally.

\section{The Cape Sable Island Perspective}

There is a strong sense of community and family present on Cape Sable Island. Many referred to the close relations coming from the years of seclusion on the Island before the construction of the causeway to Barrington in 1910. Others spoke of a trust between people and others of children being raised by family members that were not necessarily the parents of the child. One Mi'kmaq man, Danny, from Cape Sable Island asked me, 
"Well why aren't they recognized as Métis? I'm recognized as Mi'kmaq, doesn't make any sense to me."21 There's little division present among the identities on the Island, they are 'Cape Islanders', whether they identify Mi'kmaq, Métis, Wampanoag or a settler.

Sou'west Nova Métis Council has reached out to their ancestors in Massachusetts. This process has given them a degree of recognition from the Wampanoag and a sense of belonging to this denied heritage. As mentioned previously, however, this places the Métis in a difficult situation as they are in Canada and not in the United States. Therefore, without the Jay Treaty to protect their status as Aboriginal peoples, they find themselves without a proper rights-bearing category within Canada.

\section{The Mi'kmaq Perspective}

Many Métis individuals I spoke with had a sense that Mi'kmaq individuals feel threatened by the Métis movement in Nova Scotia and its growing membership. The Métis suspect that most of this fear stems from a possible alteration of who are considered Aboriginal Peoples in Nova Scotia and what resources may need to be shared and/or divided between the groups. Nancy, a Mi'kmaq elder commented briefly on this topic:

I don't want to speak very much on the issue because it makes me very upset. I will tell you this though, I grew up in the Acadian community and the Acadians were my friends. They still are my friends. However once this law passes and they were able to say they were Métis, this Métis movement started and they all started to say they were Métis. But before that they denied the fact that they had any Mi'kmaq blood. It hurts me that they say they do now when they didn't back then. That's all I have to say on the issue, because if I talk more I will just get more upset. ${ }^{22}$

\footnotetext{
${ }^{21}$ Participant Interview, July 20, 2012.

${ }^{22}$ Participant Interview, September 29, 2012.
} 
Some other Mi'kmaq had similar perspectives as Nancy and do not feel comfortable with the newly voiced Métis identities. However, other Mi'kmaq that I interviewed were fine with the Métis movement and didn't see it as a problem. Two Mi'kmaq women I spoke with were involved in an initiative to recreate the past connections that existed between the Acadians and the Mi'kmaq as they saw an importance in that early history, and working with the Métis groups allowed them to promote this cause. Another Mi'kmaq man, Eddie, did not seem to have too much of an opinion on the matter, stating, "they can call themselves whatever they like, the only thing is, as much as they fight, they're not going to get much from the government."

\section{Non-affiliated Métis}

Another interesting dimension of membership is those who decide not to affiliate with a Métis organization. Due to the nature of the political contentions that arise with the Métis in the Maritimes, some of my participants do not affiliate themselves with a particular organization yet do self-identify as Métis. Marguerite, who grew up in an Acadian family, expressed that she was concerned for the way Métis are seeking rights and believed that they were going about the process the wrong way. Others simply did not see the need to register as Métis because they knew who they were and that is all that mattered; they did not need a card to prove it.

Edgar, a member of l'Association des Acadien-Métis Souriquois, described his identity as less attached to the goals of the organization, but in his own sense of learning and exploring his ancestry. Again, self-determination can play a role in the degree to which one participates in the goals of a Métis organization. For instance, another member of l'Association des Acadien-Métis Souriquois can trace his ancestry on his mother's side 
to the Wampanoag, however, he identifies more heavily with the Acadian side of his heritage, so his membership lies with l'Association des Acadien-Métis Souriquois rather than Sou'west Nova Métis Council. This case demonstrates the diversity of the mixedblood in the Southwestern region of the province as well as the role of self-determination in Métis identities in Nova Scotia.

\section{Relationship to Land, Animals and Waters}

The complex and historic relationships the Métis have to the land, animals and waters was another theme that emerged from my ethnographic data. In this section I explore the connections and adapted techniques learned by the Métis from the Mi'kmaq for hunting, fishing and gathering. Furthermore, I speak to how these practices have continued in various capacities today and how younger generations are involved in the continuation of Métis' connection to the environment.

There is interconnectedness between the Métis and their environment as many participants rely on hunting, fishing, and gathering for subsistence. Tom, a member of Sou'west Nova Métis Council described, "I am tired of the Game Warden confronting me about my Indianness. My ancestors have hunted on this land for generations." Hank, a member of l'Association des Acadien-Métis Souriquois notes:

I left the region for many years, when I came back to retire I built this house on the same land I grew up on. Now I go rabbit and deer hunting in the same places I did as a kid, and I have the opportunity to pass these traditions onto my children. ${ }^{23}$

${ }^{23}$ Participant Interview, August 21, 2012. 
Thus, these practices have persisted over generations and represent a continuity of their way of life, rather than being based in need or requirement as the same practices served for their ancestors.

\section{Hunting and Fishing Practices}

Up until the late nineteenth century, the Mi'kmaq caught fish both through a process of spearing and the use of fish weirs and eel pots. The spear was constructed of wood with "the sharp point being flanked by two flanges to the shaft on either side, extending beyond the middle point, and so as to hold the speared fish on the barbs" (Wallis, 1955). Members of l'Association des Acadien-Métis Souriquois remember fishing with spears, or what they called a "nigogue". One member in particular noted that he still has a nigogue, but he can no longer use it to fish due to regulations.

The Acadien-Métis ${ }^{24}$ note that their ancestors would have learned to fish from the Mi'kmaq in early Acadia and that these methods and tools were adopted and in practice until recent history. They described the nigogue as being most commonly used for eel fishing by Métis and Acadians in the region. It was a very efficient method of fishing eel because of the texture of the eel, which makes it particularity difficult to catch. Jake noted the nigogue as being particularly efficient in shallow water fishing as well as in ice fishing. The adaptation of many Mi'kmaq techniques by the Métis demonstrates how "common involvement in spheres of nature, rather than any principle of shared descent, creates likeness" (Ingold, 2000: 149).

\footnotetext{
${ }^{24}$ The term Acadien-Métis will be used to refer to the practices of the members of l'Association des Acadien-Métis Souriquois.
} 
Another example of adopted fishing practices is the fish weir. Wallis (1955: 28) noted that "a semicircular weir" was called "a'bilokteg'an (net-trap)" in Mi'kmaq and was:

employed to catch fish close to shore. A swinging door in the center opens sufficiently with the incoming tide to allow fish to enter, and is closed by the receding water, thus imprisoning the fish. (Wallis, 1955: 28)

The Acadians and Métis term for the fish weir is "nijag'an", (See Figure 3) and many can still be found (not in working condition) in many Acadian communities, such as Quinan. These "weir sites became refuge areas for Acadians with Mi'kmaq kin, who were fleeing removal by the British in the mid-eighteenth century" (Chute, 1998:101). Marshall took me to a river in Quinan to see a nigog'en that remains in the river today (See Figure 4). The nigog'en was visible in the river, although it had deteriorated over time. Marshall explained that all rivers in the area would have had weirs to provide for the families in the community.

\section{Figure 3: Fish weir Operation (a'bilokteg'an/Nijag'an)}

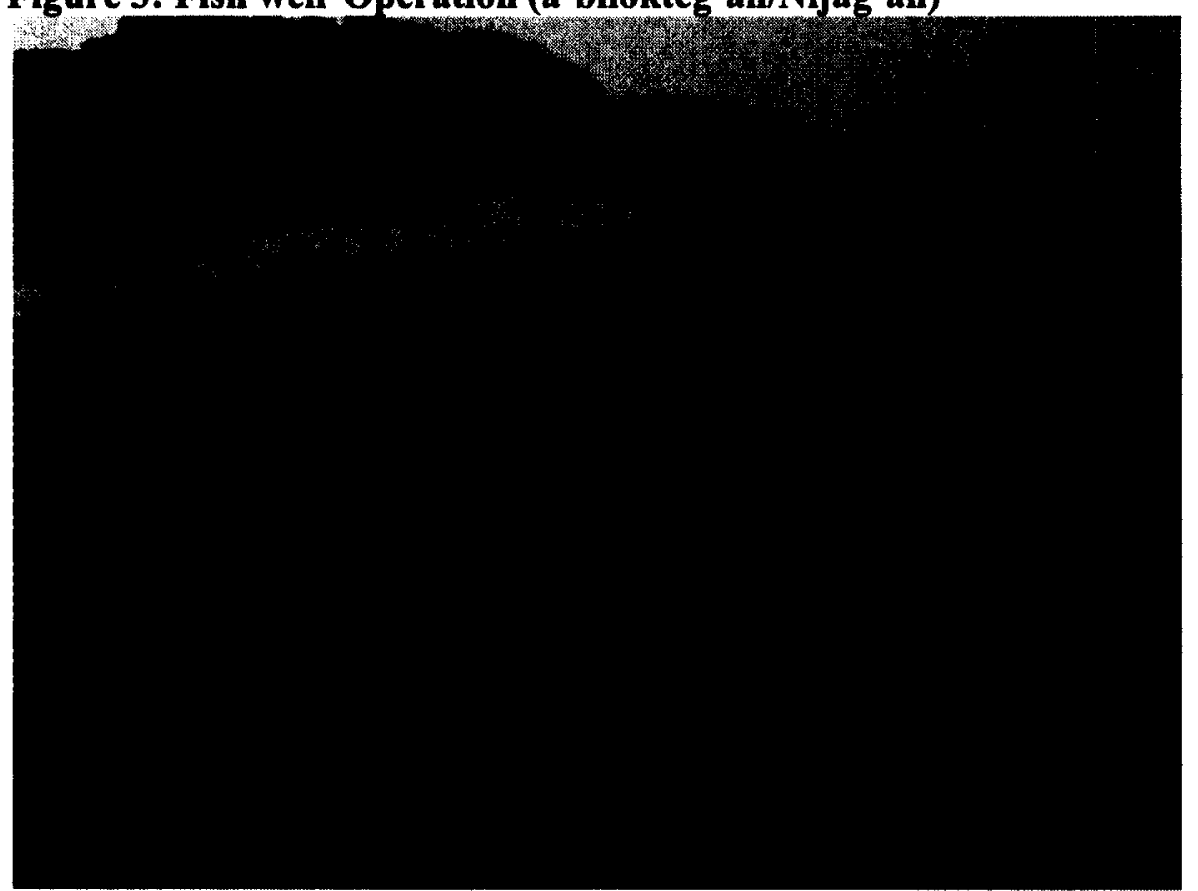

Source: "Notre paranté mi'kmaq", Musée Acadien, Rendez-vous-à-la-Baie, Church Point, Nova Scotia 


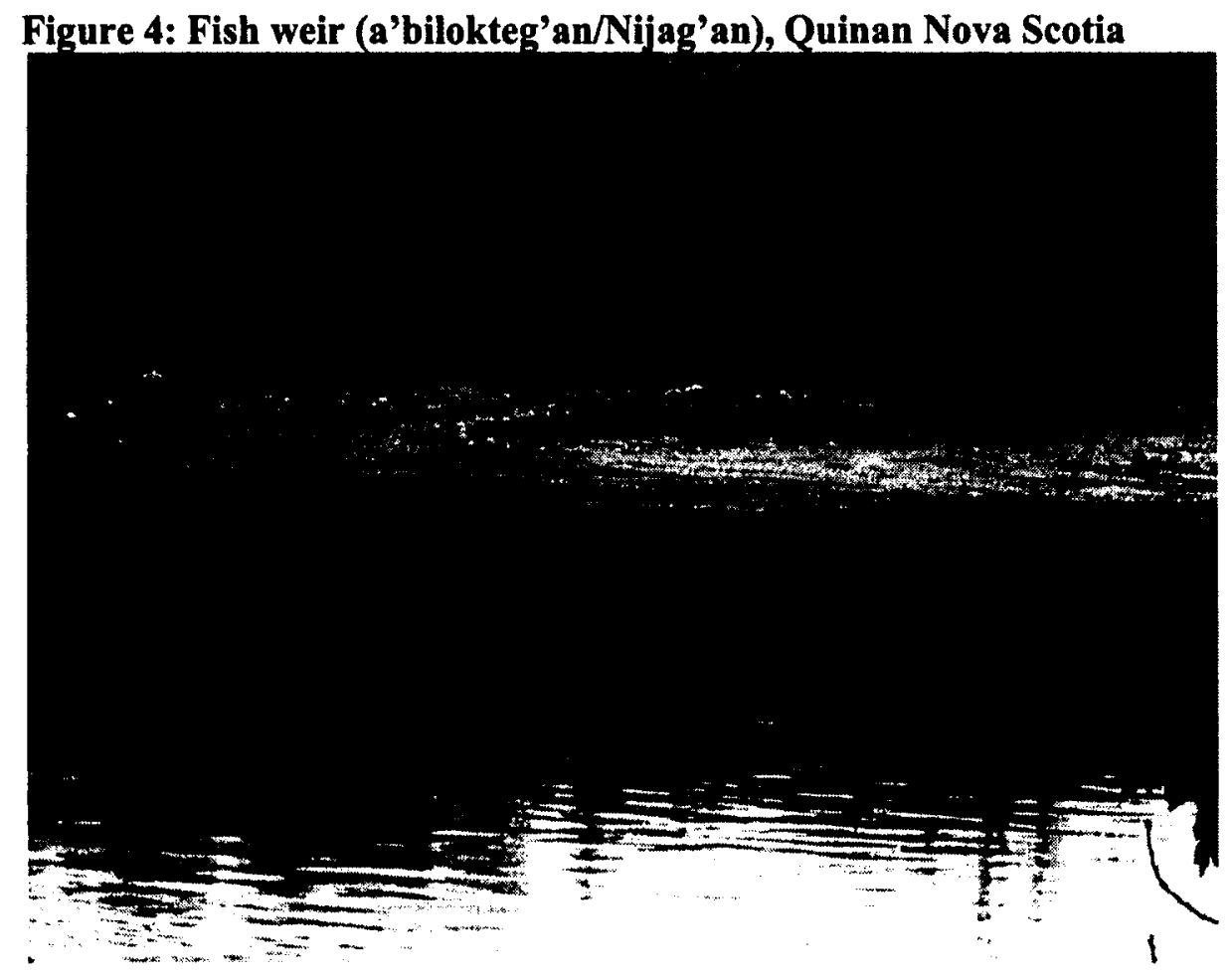

Another method of fishing used by the Acadien-Métis that was adapted from their relations with the Mi'kmaq, is an eel pot. An elder with Sou'west Nova Métis also made eel pots, a process he learned from his Mi'kmaq roots. This device uses the same technology as the nigog'en (weir), but adjusts it into a smaller space. This method was used throughout communities in Southwestern Nova Scotia to catch both salt and fresh water eels, primarily for food consumption. Participants noted the high fat content of the eel being an ideal food source in the past when other recourses remained scarce. 




Mi'kmaq commonly fished at night with a torch of cedar bark located at the front of the canoe (Wallis \& Wallis 1955). This method was employed to capture a large amount of fish at one time. The Métis on Cape Sable Island had adapted this method to catch Geese. Additionally, members of Sou'west Nova Métis Council noted that the Wampanoag Indians were also known to hunt geese at night with the use of torches. Hunters in their boat could drift in quietly amongst the birds at night with their flaming torches hiding their approach. The birds, in their confusion would be attracted to the light of the torch and could be easily clubbed or netted.

Cape Sable Island hunters improved upon this practice with a series of small fires or lanterns lit along the shore. Hunters would then employ a wooden box with a burning lantern inside, and place it in the bow of a vessel. The light of the lantern would only be 
visible from the front of the box. Then the hunters could quietly approach the geese in a small boat. Since the geese could not distinguish the background fires on the shore from the lantern's light as it approached them, the approaching light did not startle the geese, and birds could be easily clubbed, netted, or shot.

Figure 6: Goose Light, late 1800s

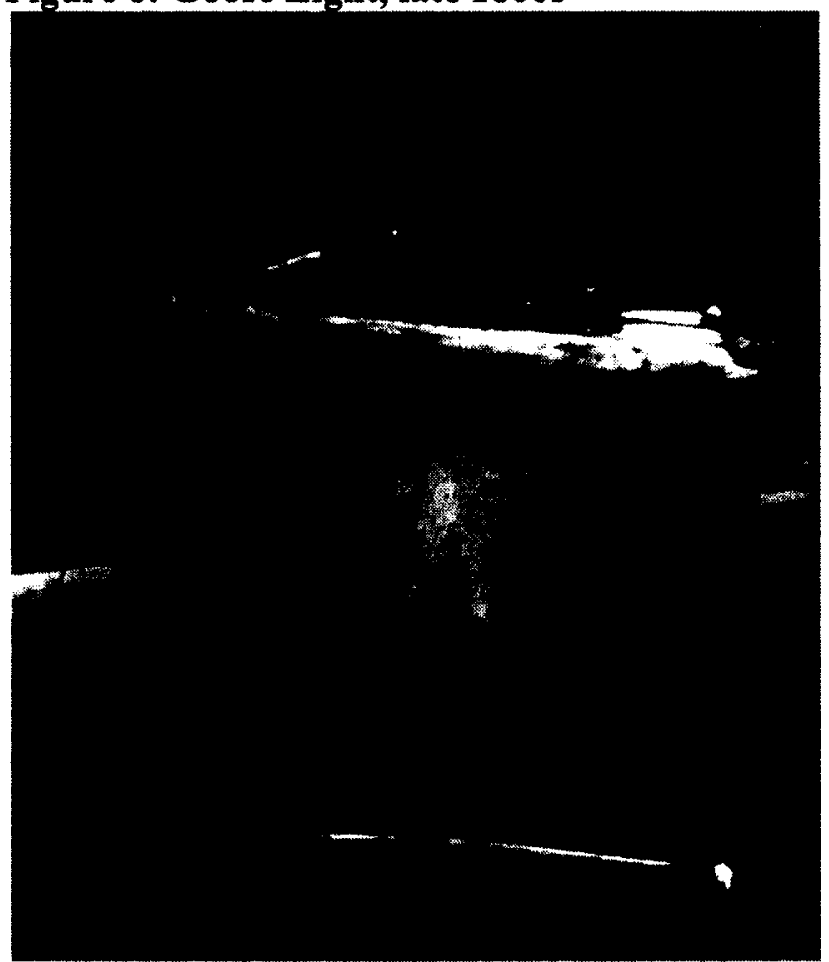

The Sou'west Nova Métis Council placed an emphasis on the importance of being able to hunt, fish and gather what is available to them on the Island. In addition to hunting geese, Métis on Cape Sable Island also hunt/hunted moose, deer, duck and sea duck. Prior to current waterfowl regulations, numerous methods were used to hunt ducks. Very noisy ducks, called third quackers, were released near the wooden duck decoys, which would help call in wild ducks. They described this method worked best on moonlight nights. In addition, eelgrass decoys were made inside of small nets to resemble ducks, and these also helped to attract wild ducks. 
For sea duck hunting off shore, small fishing vessels are spread out in a large $\mathrm{L}$ shape position, at a shotgun distance apart. Duck decoys are set up in the area, mostly wooden decoys, which were commonly called shadow decoys. These decoys were thin wooden decoys that were cut out in the shape of a duck, with the sides painted black, and anchored to the bottom. Shadow ducks floated in the water and cast a shadow, and looked like a duck, to birds in flight in the distance. On some occasions, the hunters would wave a red flag for a short period to get the attention of ducks off in the distance.

Gary, a member of l'Association des Acadien-Métis Souriquois, noted that his uncle instilled in him a great deal of respect for the animals they were hunting. Much like the Mi'kmaq, the Acadien-Métis hunt beaver, bear, moose (in the past) and deer. Gary was taught that he was not to take a shot unless he was able to instantly kill the animal, in the case of a deer, through the head, between the eyes. He said he always thanked the animal after the shot, but since coming into further awareness of his Aboriginal roots, he now thanks the animal before. He recounted one occasion when he shot a deer in the back of its head, with the deer looking away from him. This experience bothered him, he said, "it just didn't feel right," ${ }^{25}$ even though it was still an instant kill, he did not look the deer in the eyes.

Gary wants the animal to be looking directly in his eyes when he kills it. This practice demonstrates a respect to animals as the animal offers itself to the hunter (Krech, 2005:81). Ingold (2000:13) recounts a similar perspective by Cree hunters:

Now the Cree, native hunters of northeastern Canada, have a different explanation for why reindeer - or caribou as they are called in North America - are so easy to

${ }^{25}$ Participant Interview, September 16, 2012. 
kill. They say that the animal offers itself up, quite intentionally and in a spirit of goodwill or even love towards the hunter. The bodily substance of the caribou is not taken, it is received. And it is at the moment of encounter, then the animal stands its ground and looks the hunter in the eye, that the offering is made.

In addition to the way he kills the deer, Gary was taught how to treat the carcass

respectfully after the kill. They would remove the hide as quick as possible to let the heat escape and then cool the meat as quickly as possible, in a lake if it is accessible. This quick response to treating the animal displays respect for the animal along with respect to not waste the meat.

Similarly to how Gary learned how to hunt and treat an animal, Roger, from Sou'west Nova Métis Council expressed learning traditional ways of living from his parents as well as Mi' $\mathbf{k m a q}$ people in the area. One of particular importance in his life was a Mi'kmaq trapper. This educational experience Roger gained through his childhood influenced the way he hunts and gathers today, and has inspired to teach others about the culture.

Many Métis stressed that they do not hunt for sport but rather hunt for consumption and emphasized this as a significant difference. The Métis see disrespect in letting the animal suffer. As Gary explained, "if you are taking a shot in the shoulder the deer could run and suffer for days before you find it. The meat is no longer as good to eat, and the animal is in distress. ${ }^{, 26}$ Hunting is certainly a practice that is not being lost in the region and many of my younger participants, Lana, in her early twenties, stated:

I like to go hunting and I like to go fishing and being outside so I guess you can kind of tie that back ... my family has always done that and I still like to do it. We've kind of grew up with it, and even though its not solely Métis you can kind

${ }^{26}$ Participant Interview, September 16, 2012. 
of bring that back to that its always been done that way and we kind of continue on with the traditions. ${ }^{27}$

Eleanor elaborated further:

Well for me I'm really glad that I have all those parts, that I've inherited the cultural parts. I think that at some point now, we're going to get back to that. You hear about people in cities that are allowed having little gardens and they borrow each other's yards that are allowed. So to me its, the best part of it is being associated with the land and nature, that's how I see myself a lot as being Métis. ${ }^{28}$

In many ways the hunting that is practiced among the Métis in Nova Scotia can be seen in terms of a reciprocal exchange between animals and humans (Nadasday, 2007). Many participants, as Gary explained, described the importance of looking into the animals eyes before taking the shot, as a way of acknowledging the animal was giving itself to the hunter. Others emphasized the importance of leaving tobacco or sage behind after talking anything from the land. These practices ensure this relationship between the hunters and the animals is on-going and remains reciprocal (Nadasdy, 2007; Ingold, 2000).

\section{Food and Gathering}

For many participants, there was no separation between their culture and the environment. Many participants described hunting and living off of the land as important to them and that being in the woods brought them a sense of peace. Acadien-Métis individuals placed an emphasis on dishes such as râpure (rappie pie in English) and fricot as being Métis foods, although they are more commonly seen as Acadian dishes. These two dishes, most commonly prepared with potatoes and chicken are also prepared with various types of game as well as clams. As Rachel explained:

${ }^{27}$ Participant Interview, August 9, 2012.

${ }^{28}$ Participant Interview, July 26, 2012. 
There are distinct things that are Acadian like rappie pie, so maybe that's Métis? It isn't Mi'kmaq. Using the rabbit - the rabbit was Mi'kmaq, and then the put it in a pie, which you could call Métis. Eat whatever you can get. If you didn't want to starve to death you would eat rabbit for 6 months... you had to dress it up. ${ }^{29}$

Further, Rachel explained to me the importance of clams to their people and how she and her family harvest them throughout the year through various methods, usually digging on tidal flats at low tide, a process learned from the Mi'kmaq, or they sometimes dive to gather clams. Many Acadien-Métis emphasized the importance of clams for consumption, many enjoy eating them raw and also for use in dishes such as râpure, furthermore, they have developed preservation techniques and therefore have clams year-round.

After an interview in Quinan, Marshall took me on a drive to see Meat Rock. Meat Rock has a strong significance to the Acadian/French derived Métis in the area as it was once a meeting place for their people. The rock is located deep in the woods of Quinan, now surrounded by numerous hunting camps. Meat Rock acted as an end point for hunters to divide up the meat of a successful hunt and also as a meeting place where the Mi'kmaq would share their meat with early Acadian settlers, creating a debate as to if the name of the rock is "Meat Rock" or "Meet Rock."

A notable gathering tradition in Quinan was blueberry picking, as well as the gathering of other berries and plants. Blueberry picking would involve many in the community moving into the woods during the gathering season to pick berries. Meat Rock continued to be an important meeting place in its centrality to this gathering practice. Today, it continues to serve as an important location in the community as it is central to various paths and roads that are used in current hunting practices.

${ }^{29}$ Participant Interview, August 21, 2012. 
Figure 7: Meat/Meet Rock (La Roche de Viande) myths, Quinan, Nova Scotia

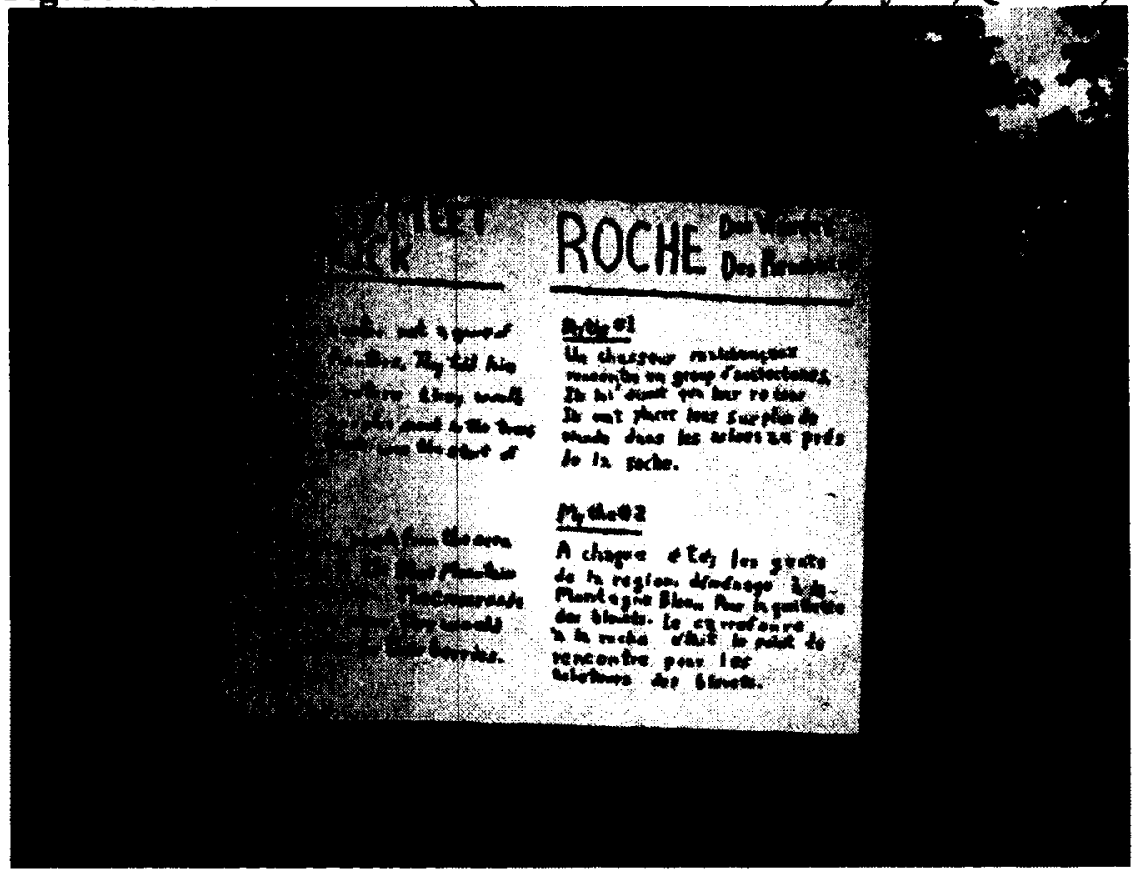

Figure 8: Meat/Meet Rock (La Roche de Viande), Quinan, Nova Scotia

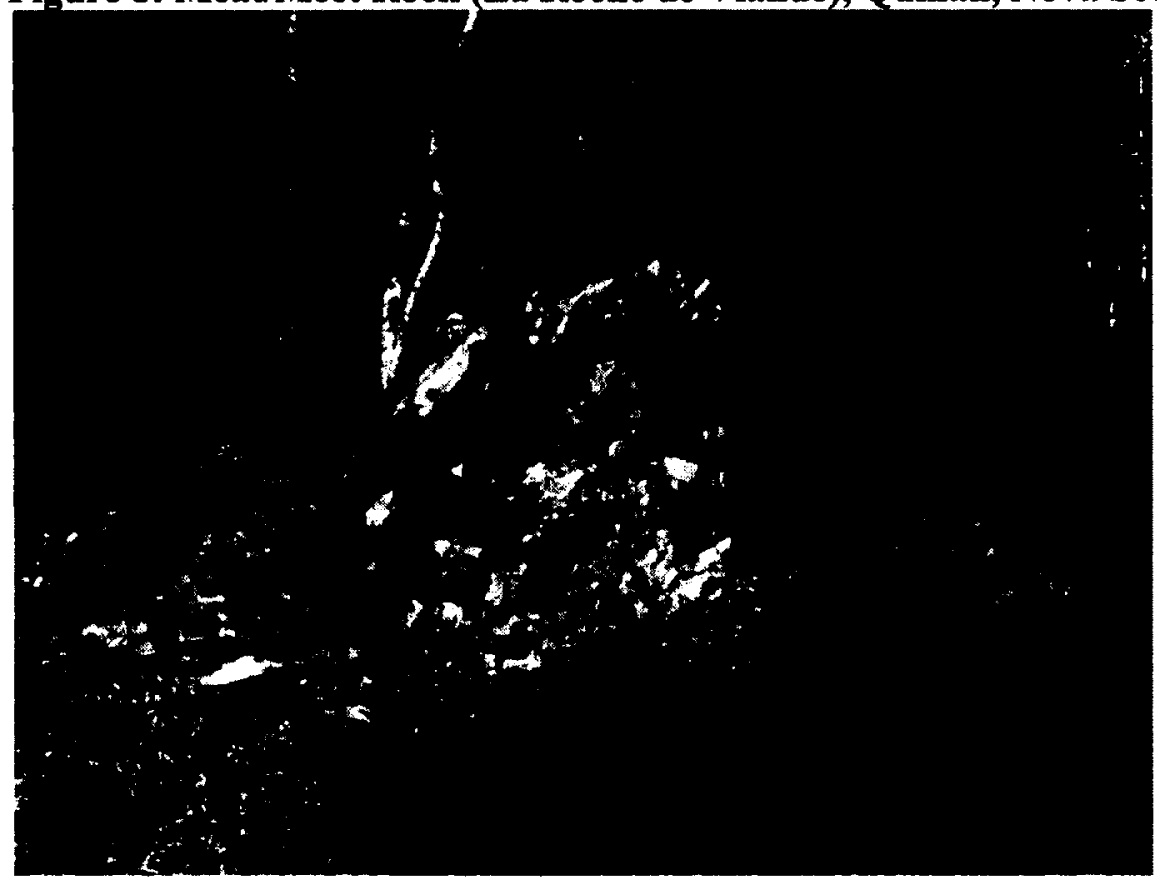


Gathering is a major part of living as a Métis in Nova Scotia and contributes

significantly to their food as well, as Eleanor elaborates:

The other ways are really practical ways like the hunting and the gathering. I gather what I can from my environment you know to eat or to get what I need um instead of going to the store. I admit, I'm not always doing it and sometimes it's a mixture between the modern and the old but the gathering is a huge huge thing. Right now it's blueberry season so I went one day for like four hours and its like, to me, its like insane, in the back of my mind its like I have to pick blueberries before they're done because $t$ this is it before they're done for the year! ${ }^{30}$

An Elder of Sou'west Nova Métis Council, Roger, noted his experiences on the Acadian shores and how he can even see the Métisness in their culture, how they still live off the land and have very traditional food, especially his experience when eating râpure.

Members of Sou'west Nova Métis Council noted the techniques residents of Cape Sable Island have developed in cooking sea duck. They described sea ducks normally have an oily, fishy, taste and smell. Residents developed a method to eliminate this problem by stewing or boiling the sea ducks in a mix of vinegar and molasses to reduce the fish smell and taste. Bog apples also grow in large swamps on Cape Sable Island, and they are commonly baked and preserved for the winter.

The Acadian-Métis use Rockweed as natural fertilizer in their gardens and as a preservative and natural gelatin in jams and other canning. Members of l'Association des Acadien-Métis Souriquois stressed their disappointment that a joint federal and provincial governmental regulation had been implemented to forbid them to harvest rockweed from the shores. Ugarte and Sharp (2001) attribute this regulation to concern of the management of marine resources after the collapse of fisheries along with concern for the effect of the harvest of the plants on this resource. This management strategy was

${ }^{30}$ Participant Interview, July 26, 2012. 
employed primarily to address the impact of commercial harvesting on Rockweed, in particular by Acadian Seaplants Limited (Ugarte \& Sharp, 2001) and did not consider the impacts the regulation would have on other groups who harvest the resource. Alice spoke of the importance rockweed served for her garden as fertilizer and not knowing that she now needs a permit to continue this practice she learned from her elders. The implementation of these regulations restricts a way of life that has been passed down through generations.

\section{Relations and Respect}

When Aboriginal peoples live for generations on particular lands, they can develop a deep sense of attachment and familiarity with the land and waters, along with an awareness of the other living elements that are in their environment (Krech, 2005: 79). This attachment creates a deep sense of respect for the land, and in many senses a spiritual attachment. Alice, a member of l'Association des Acadian-Métis Souriquois described the importance of going fishing with her father each Sunday afternoon rather than going to church like most others in her community. Ingold (2000: 149) elaborates on this type of environmental relationship:

As hunters and gathers have explained to their ethnographers, with remarkable consistency, it is essential to 'look after' or care for the land, to maintain in good order the relationships it embodies; only then can the land, reciprocally, continue to grow and nurture those who dwell therein.

This experience of fishing with her father taught Alice to respect her environment and her elders. She spoke of how she and her father would catch enough fish to bring to those in the community that can no longer fish for themselves. Smith (1999: 110) stresses the importance of sharing: 
Sharing is a good thing to do, it is a very human quality. To be able to share, to have something worth sharing, gives dignity to the giver. To accept a gift and to reciprocate gives dignity to the receiver. To create something new through that process of sharing is to recreate the old, to reconnect relationships and to recreate our humanness.

Alice's father was one that had a great respect for the land, other Métis spoke of him kindly and referred to his knowledge and that he knew how much to take from the land and would take no more than that amount. Similarly, Eleanor remembers crying after seeing people standing at the top of a river with nets catching jumping fish in abundance, she described this as "not fair to others" and that it was "not the right time of year." This experience was upsetting to her because of the disrespect for the fish, and the impact on conservation and others who might have needed that fish.

Ralph, of l'Association des Acadien-Métis Souriquois, said that when he was young he remembers seeing natives in his back yard and when he'd ask his parents about it they'd just say "Leave them be, they have the right to use the land, it's their land." He learned to respect the Mi'kmaq and their way of life. He said that even after the deportation, his family continued to respect the Mi'kmaq and let them use the land they owned without question: "I remember the Indians coming and camping for the summer. My father was always accepting and told us that it was their right to use the land." 31

Métis elders play a significant role in the continuation of practices and the transmission of cultural attachment to younger generations. Pierre, a member of l'Association des Acadien-Métis Souriquois, spoke of his late father and how he used to have Métis gatherings. He described being at a Métis gathering after his father's death and that an eagle flew overhead. It reminded him that his father was with him. Patrick

${ }^{31}$ Participant Interview, July 20, 2012. 
recounted a story of having the honor to know a Métis man when he was a young boy. Patrick used to go fishing and hunting with him and it cultivated a strong love for nature in Patrick's life. Along with developing his knowledge of the land and sea, spending time with this Métis man in the capacity that he did taught him a great respect for Métis and First Nations peoples. Patrick described him as a pivotal person in his life that led him to make the career choice in the environmental sector that he did.

\section{Views on Rights}

"I actually hope Métis don't get rights in Nova Scotia," possibility of Métis gaining rights in the province. I think this was the most surprising response I heard from someone identifying as Métis in my study. His sentiments here refer to his fear of what might happen to the resources in the province if the Métis are granted rights similar to those of the First Nations. He explained that many who could qualify, as Métis don't necessarily possess the respect for the land and animals as many Métis do and his fear is that those people would deplete the resources for those who do.

Conservation is at the core of how the Métis in Nova Scotia wish to approach the possibly of rights. The Métis have a respect for the environment and practices that have an Aboriginal basis, therefore, any negotiations they will undertake in relation to hunting, fishing, and gathering rights must be done so within regulation and resource management because they do not want to see a diminishment of any resources as a result of Métis rights. In interest of conservation, some areas of forest in the area are being deemed as "walking only" that is hunters are unable to drive ATV's to these areas. This causes concern among the Métis as these areas were once part of the land that their families

${ }^{32}$ Participant Interview, August 14, 2012. 
would hunt and gather, but because they are growing older, they are not able to get to these areas on foot, therefore, placing it into the "traditional ways" lens, where ATV's, a modern tool, are being forbidden.

Jacob, a member of L'Association des Acadien-Métis Souriquois, recounted a story about a man who came into his work asking him about his involvement in the l'Association Acadien-Métis Souriquois. The man inquired if the organization would be interested in a test-case for court as he had been charged illegally digging worms in a closed area. Jacob decided that it was out of the character of what the organization stands for in respect to conservation, as the man was digging for worms in a closed area. On another occasion, Jacob pondered if a court case on a less controversial issue than hunting or fishing would be more successful to determine Métis rights in Nova Scotia. He provided the option of a court case on rockweed from the shore, which they use as fertilizer in their gardens, in jams and in other traditional ways. He thought that attempting to ascertain their Métis rights based on a simpler tradition such as this may prove to be less hassle and more successful in court.

Anderson (2004) notes that wildlife management is not about managing animals but managing people. A few years ago, Sou'west Nova Métis wanted to host a feast for their community and catch a sufficient amount of fish to feed the community. Governmental regulations would not allow them to have the amount of fish they needed to feed the community even though it was for a Métis feast and not for sale and profit. They even filed for a special license in order to explain that it was for Aboriginal purposes and it was again denied. 
L'Association des Acadien-Métis Souriquois place an emphasis on the fact that they do not want to impinge on the rights that the Mi'kmaq already possess over the land. In terms of respect and not wanting to affect the current state of resources in the province, L'Association des Acadien-Métis Souriquois state in their constitution that:

To enter into agreements with the Mi'kmaw People [is]... to negate any perceived or actual threat, conflict or competition associated with the objects of this Society. The Society does not wish to apportion the benefits and rights that belong to the Mi'kmaw People.

The organization therefore attempts to build relationships with the Mi'kmaq rather than create further contention through a misunderstanding of their intentions concerning rights and land use. The Kespu'kwitk Métis Council emphasized that they have developed a plan of action in conjunction with their court case that places a strong emphasis on conservation. Their intention, like those expressed by l'Association des Acadien-Métis Souriquois, is to not deplete resources. Due to their ongoing court case, the Kespu'kwitk Métis Council did not wish to elaborate further on this plan of action.

Regardless of whether or not Indigenous peoples subscribe to western ideas of conservation - they do possess a comparable knowledge and respect (Krech, 2005:81) The Acadien-Métis placed an emphasis on saving what they viewed as privileges. They view privileges as the past practices and have not yet come under significant regulation, such as clam digging. They wish to save these privileges and turn them into rights, as Hank elaborated: "I live a Métis lifestyle. I believe I have the right to live off the land for my own consumption." The Métis want to keep what privileges they have now, and gain some back that they have lost and continue their way of life through the use the practices that have persisted over generations. 


\section{Language, Relations and Respect}

In this section I explore the importance of language, inter-ethnic relations and respect in Métis identities and how these themes attach to early métissage in the province. In addition, I explore the way that the Métis have been able to build upon their identities to develop relationships with the other Aboriginal peoples and settlers through education and an increased awareness of their presence in the region. These ethnographic data build on the importance of these historic relationships and examines the ways in which they can serve in the Métis cause in the present and future.

\section{Historic Linguistic Encounters}

Canada is a country that was built on the development of crucial relationships between Aboriginal Peoples and European settlers. Early settlement of Nova Scotia would have involved the newcomers learning the language of the Mi'kmaq. Founding members of early Acadia, Charles de Biencourt and Charles de La Tour, both learned Mi'kmaq upon their arrival in the province (Ross \& Deveau, 1992: 12). There is also evidence of early settlers having to learn the language of the Wampanoag (Silverman, 2005). Settlers and Aboriginal Populations in Canada developed relationships that evolved and interconnected over centuries, as they developed ways of relating and surviving - these ways of living together "became habit, became culture" (Saul, 2008: 57). These linguistic linkages are evidence of developing a way of relating and surviving at the most essential level that has left a mark on both the settler and the Aboriginal languages.

Members of both l'Association des Acadien-Métis Souriquois and the Kespu'kwitk Métis Council are connected through the Acadien Language. The Acadian 
language is unique in that it has retained a significant amount of early modern French that is no longer present in France; it also has a noticeable Aboriginal linguistic influence (Faragher, 2005). Augustine (2008) describes Acadian-Mi'kmaq derived Métis peoples as communities that were misclassified as Acadian due to their language of Acadien French which incorporated aspects of both Mi'kmaq and French language.

Régis Brun (2003) notes the Amerindian influence the Mi'kmaq and the Maliseet had on the development and enrichment of Acadien French. Maissignon (1962) emphasizes that the Acadians adopted certain terms from the Mi'kmaq and Maliseet which then replaced the French terms that would have been used during the seventeenth century. Many of these terms referred to place names (Brun, 2003). It is also worthy of note that Acadians had a tendency to use Mi'kmaq place names for their own settlements (Faragher, 2005:78-9). Brun (2003) further explains that as Amerindian words replaced French words in the language of the Acadians, the same process occurred on the part of the Mi'kmaq and Maliseet, with many French words becoming part of their languages (See Appendix F \& G for common interchanged words).

Faragher (2005) notes that early French settlers would have communicated with the Mi'kmaq in "trade jargon" where these words would have become common knowledge, and then would have been incorporated into the language itself. Furthermore, it is noted that many settlers were illiterate and could not sign their names. In these cases, many would use native-style ideograms, adopted from the Mi'kmaq, in the place of a signature (Faragher, 2005: 78). 


\section{Current Language Efforts and Relations}

Early on in my fieldwork, I had not entirely grasped the dialects of Acadien French present in the region. Many participants reassured me that the dialects change from village to village and sometimes Acadians have a hard time understanding each other. During one instance, a potential participant began to speak quite quickly in Acadien, and fortunately, I was able to understand most of what he said, especially since one of the things he mentioned was that he had agreed to an interview. Despite this understanding, as I walked back to my car all that was running through my head was, "I really hope I start understanding these Acadien dialects quickly."

Fortunately, my hopefulness to understand Acadien was not as far-fetched as I had thought. One afternoon, I received a phone call from Félix, an Acadian man from the community of Clare. He had heard about my project from some members of l'Association des Acadien-Métis Souriquois and a participant had given him my number. When we met, we spoke for hours about the Acadien language and he began to tell me about how he has undertaken a project to record the Acadien language phonetically. It was not long after that that I was taking lessons from him to improve my comprehension of the local dialects. There were three dialects of Acadien between the two French/Acadian derived groups I was working with.

The argument Felix puts forward is that the Acadian dialect is more than just a dialect of French, but a language and furthermore a Métis language. Looking at the Acadian language from this perspective led to an analysis and a link to the Métis that was more prominent than I had initially thought. As we covered each book where he had recorded Acadien in phonetic script, there were signs pointing to the Mi'kmaq and the 
métissage that exists in the Acadien language. Table 2 is an excerpt from one of the Acadien language books he wrote. Mi'kmaq words emerged in the texts and Mi'kmaq derived words as well. Félix then shared with me that this project has led him to learning the Mi'kmaq language as well. Although he does not identify as Métis himself, he does work with l'Association des Acadien Métis Souriquois and supports the Métis movement. He also hopes that his work in recording the Acadien language will aid the Métis in their recognition.

\section{Table 2: The Birth of the Acadien Language, Acadien depicted through Phonetics}

\section{I-9. La Nésäs Dla Läg Akadièn}

Käske lé Prâmyé Fräsa arivir o kùmäsmä dé séz sä, uun Kùmunoté Distëkt avèk uun Läg Distëkt kùmäsi. Le Lägaj Miigmâ èta pu ëpârtä kla Läg Ägléz é astêr. Le Mètisaj nù zêpakt äkor ! Sartë Lëĝwiist kwéyö klé lyé Akadjë ètyö dé Pwatvë.

Source: La Läg Akadjèn, Lé Près Dla Bé, 2011.

In addition to learning from Félix, I found indicators of language similarities through my travels in the region, particularly at Acadian Museums. Table 3 is a reproduction of a chart found at Le Musée Acadien at Rendez-vous-a-la-baie, outlining linguistic similarities between Acadien and Mi'kmaq. This table was part of a large display that paid tribute to the historic relationships that existed between the two populations and the influences they had on each other's cultures. 
Table 3: Linguistic Similarities between Acadien and Mi'kmaq

\begin{tabular}{|l|l|l|l|}
\hline & & GLOSSAIRE & LEXICON \\
\hline Mot mi'kmaq & Mot acadien & Mot francais & Mot anglais \\
\hline Mi'kmaq word & Acadian word & French word & English word \\
\hline gawi & Kâwedge & aiguille de porc-épic & porcupine quill \\
\hline matues & Madouesse & porc-épic & porcupine \\
\hline pagosi & Picogie & Nénphar & water lily \\
\hline maskwe & Machecoui & écorce (de bouleau) & birch bark \\
\hline mitihikan & Meteghan & roches bleues & blue rocks \\
\hline
\end{tabular}

Source: Adapted from Musée Acadien, Rendez-vous-à-la-Baie, Church Point, NS.

The linguistic similarities between the Mi'kmaq and the Acadians have become a point of interest to the Métis who derive from the historical context of French-Mi'kmaq intermarriage. One member of l'Association des Acadien Métis Souriquois has compiled a list of Mi'kmaq derived Acadien words that are still used today. Table 4 demonstrates these works with both the French and English translations. Other participants noted they have also compiled their own lists of words as they realize that they are related to their aboriginal roots. Léon mentioned a list he had complied years ago with other family members that he had showed to his nephew one afternoon. The nephew did not recognize many of the words, which to Léon, demonstrated that the language is in a decline. 
Table 4: Mi'kmaq derived Acadien terms

\begin{tabular}{|l|l|l|}
\hline Acadien & Francais & English \\
\hline Na & Voilà & That's it \\
\hline Mam & Mère & Mother \\
\hline Nanane & Norriture pour bébé & Baby food \\
\hline Kokiches & Premières dents & First teeth \\
\hline Caristeaux & Bottes de peau & Hide boots \\
\hline Babiche & Tissage de peau & Raw hide weaving \\
\hline Tobagane & Traineau & Sleigh \\
\hline Tomahawk & Hache & Ax \\
\hline Wisinne & Baton & Stick \\
\hline Mêmetchais & Marécages & Swamps \\
\hline Tamaracks & Mélèzes "violin" & Larch trees \\
\hline Caribou & Reene du Canada & Reindeer \\
\hline Beauwiche & Perdrix & Partridge \\
\hline Kaekagougie & Corneille & Crow \\
\hline Coucougouêche & Hibou & Owl \\
\hline Titigris & Grand-duc & Great-horned owl \\
\hline Machequoui & Écorce de bouleau & Birch bark \\
\hline madouesse & Porc-épic & Porcupine \\
\hline Cawidges & Aiguilles de porc-épic & Porqupine quills \\
\hline Boucane & Fumée & Smoke \\
\hline Sissiboo & Grande rivière & Great river \\
\hline Bonhommecouèche & Marmotte & Woodchuck \\
\hline Mascouèche & Raton laveur & Raccoon \\
\hline Chebec & Lieu étroit & Narrow place \\
\hline Gwégusse & passage étroit & Narrow passage \\
\hline Ouaouarons & Grenouilles & Frogs \\
\hline Picogies & Nénuphars & Water lilies \\
\hline Nigogue & Lance à anguille & Eel spear \\
\hline Nijagan & Enclos pour prendre le & Fish weir \\
& poisson & \\
\hline Moiacs & Eiders & Eiders \\
\hline Couimoux & Huards & Common loons \\
\hline Mawgouèches & Huards à gorge rousse & Red-throated loons \\
\hline Quiggueniche & Havre à deux entrées & Harbour with two entrances \\
\hline Canot & Canoe & Canoe \\
\hline Pagayes & Avirons & Paddles \\
\hline Gaspareaux & Sorte de hareng & Alewives \\
\hline Poulamons & Poisson des chenaux & Frost fish "tomcod" \\
\hline Tenoine & Tendon & Tendon \\
\hline Chicabennes & Patates savages & Artichokes \\
\hline Souriquois & Les homes de l'eau salée & Salt water men \\
\hline Source: Pantipan & \\
\hline
\end{tabular}

Source: Participant. 
Léon is a supporter of Félix's attempt to revive the Acadien language. He has gone through the process of learning how to read the language phonetically, and believes that it has potential to benefit Acadians and Métis in future generations. Other participants, as thrilled as they are with the phonetic depiction of Acadien, mentioned that Félix might be ahead of his time with the presentation of written Acadien, just as many people are ready to face that they are Métis. Lee Ann described the benefits that will come from the phonetic depiction of the Acadien language to future generations. She explained that the Acadian School Board was discouraging the use of Acadien and many students are losing their language as they learn standardized French.

Language can tell us a lot about a culture. The Acadian language can be seen as a language that has developed though the centuries of colonization in the Maritimes. The Kespu'kwitk Métis Council along with the Acadien-Métis looked to French, and specific dialects of French or Acadien that demonstrated a unique linguistic characteristic to their Métis cultures. Members of Kespu'kwitk Métis Council who have spent time developing relationships with Métis in other provinces of Canada compare their way of speaking as similar to Michif. Randal compared a paper he had depicting Michif speech as similar to the way his grandparents used to speak.

Members of Sou'west Nova Métis Council have made continued effort to learn from their cousins in New England. In the process of comparison they have noticed that there are linguistic similarities between them, along with the use of common terms. Through their relations with the Maspee Wampanoag in New England, the Sou'west Nova Métis Council have found similarities in their speech to the Wampano-Quiripi Vocabulary (See Appendix H). Inhabitants of Cape Sable Island possessed a unique 
dialect of English. Participants recognized their unique way of speaking, jokingly referring to it as "Cape-Islandese." However, their way of speaking is likely linked to their Wampanaog ancestors, as Silverman (2005:19) describes early European's learning of the Wampanaog language:

Less determined men would have resigned this lofty vision to fantasy since the first task was to learn the "very difficult, irregular, and anomalous" Wampanoag language. The Indians tongue was full of "Diphthongs or double sounds... as ai, au, ei, ee, eau, oi, oo" and threw together multiple consonants in words like "Ahuehuhkq.

Silverman (2005:19) describing the Wampanoag dialect further as "compounding words, making one out of several." This is a very similar to the way Cape Islanders speak, very fast as they string many words together. Cape Islanders had a unique accent that was distant to those who lived on the island and those who hailed from the area. It was something that they definitely saw as distinct.

\section{Education and Awareness}

All three Métis organizations placed a significant emphasis on education. All made efforts to help with and/or provide funding to young members who were seeking to attend post-secondary institutions or aid in the joining of the military or RCMP. There is a push for educating the public about the presence of the Métis in Southwestern Nova Scotia. Over the course of my fieldwork, I visited a number of historical sites, museums and archives, including, Grand-Pré National Historic Site, Port Royal National Historic Site

La Roche de Viande, Musée Acadien at Rendez-vous-à-la-Baie, Village Acadien and Musée Acadien in Pubnico, and the Tusket Islands did exhibit representations of métissage and Mi'kmaq-Acadian historic relations. This continued attachment to 
education, passing the knowledge on and between peoples, and the transcription of the Acadian language provides tangible material for the language to persist in the future.

Many members of each organization engaged in teaching and educational events that spread the knowledge and awareness of Métis in the province. Albert spoke of speaking to groups of young boys about hunting and gathering practices; he viewed this as an important part of his Métis identity because it allowed him to pass on the cultural practices to future generations. Lee Ann spoke of hosting a deer hide tanning workshop for members of the Métis community. Members of Sou'west Nova Métis Council told me about how a group of high school students from Ontario came to the Island to learn about their customs and practices. These efforts are increasing the awareness of the Métis in the province and providing grounds for learning for many who lost cultural aspects of their identities.

One afternoon I received a phone call from one of my participants, Randal, from the Kespu'kwitk Métis Council asking me if I would like to join he and his wife for, what he described as, a Métis barbeque. After getting lost a few times on my way I pulled up to a cabin on a lake where his directions finally led me. Relieved to have found the place I pulled into the driveway and Randal met me in the yard. He took me into the cabin; this is where they spent their summer months as they lived in Yarmouth. Many of my participants had cabins or camps similar to this, often used when hunting and fishing in various seasons as well.

It was a lovely evening of food, conversations, and learning about the efforts that Randal and his wife have made to educate the public about Métis issues. Both he and his 
wife have made various presentations at Acadian and Aboriginal events about the Métis and travelled to Manitoba to learn more about the Métis peoples there. He showed me educational material he had developed to teach younger generations about the Métis culture in Nova Scotia. He had display boards filled with dream catchers, drums, sweet grass, and sage, and binders filled with information about Métis in the Maritimes as well as elsewhere in Canada. He explained to me that education is a main goal of their council and that they take every opportunity available to them to go into schools or various youth groups and present their material and interact with the younger people. Randal spends much of his time going to schools and giving presentations to children on the Métis and the crafting of drums.

I had a similar experience as I entered Temps Passée Acadien-Métis, an educational gathering to educate people on Métis culture and identity, during the Festival Acadien de Clare. Théo, who coordinated the event, had an impressive display of teepees, canoes, flags and activities set up in a field. There were children running around playing in various displays and in one tent they were learning how to weave a birch-bark basket. As I approached Théo, he was in the processes of explaining the construction of a birch bark canoe. I tagged along as he continued explaining various aspects of his display to the couple. As I followed them into the biggest of the teepees, I remembered when I had been at this exact place a year earlier as my ideas for this project were beginning to come together and hearing Théo talk about his teepee increasing my interest in the topic.

Théo began to refer to the flags he had hanging from the side of the teepee, explaining first the Acadian flag on the left, then the Mi'kmaq flag on the right and then in the centre of the two was the Métis flag, a deep royal blue with a white infinity symbol 
in the centre. The couple was very intrigued, Théo continued "Là, c'est le drapeau des Métis, c'est pour les deux cultures ensemble."33 The couple thrilled to have had such an experience as they travelled through Southwestern Nova Scotia left continuing to admire the paintings on the teepee. I finally got my chance to talk to Théo. I explained my project to him and he was very interested in being involved. As we walked around the site of Temps Passée Acadien-Métis and he explained to me the importance of educating the public, tourists and especially children about the Métis in Nova Scotia.

In addition to education of the culture present in museums and historic sites, I was invited to an event called Journée pour sauvée la langue Acadien one afternoon by Félix. This event was put on in attempt to increase public awareness of his work in phonetics and the benefits that this could have in saving the Acadian language. It included participation from L'Association des Acadien Métis Souriquois along with other folk artists from the area and also included some Métis artifacts from the region, Archives from various Acadian villages, and a feast. The event was well-attended and served to raise awareness of the Acadien language and its preservation for future generations in written and recorded form in addition to oral transmission.

\section{Building Relations of Respect}

Linguistic similarities have provided a platform for the Métis to build upon their relationships with the Mi'kmaq and Wampanoag peoples. Members of the Métis organizations who have gained respect from Mi'kmaq First Nations in the area are now commonly invited to attend feasts, sweat lodge ceremonies, and various other events. While a tension continues to exist about the category of Métis building relationships

\footnotetext{
${ }^{33}$ Participant Observation, fieldnotes, August 2, 2012.
} 
based on linguistic similarities, a shared history and mutual respect have allowed the groups to coexist and build on these relations. Patrick, a member of l'Association des Acadien-Métis Souriquois, recounted one such experience:

We were invited to attend a weekend at Bear River; there were about four or five of us who were Métis, from both l'Association des Acadien Métis Souriquois and Kespu'kwitk Métis Council. As we arrived, they always had flags hanging, but this time, the Acadian flag was there. Alex was so touched he almost came to tears. $^{34}$

This experience shows the nature of the relationship that is growing between the two groups as they mend their past and build towards a present and future where they can work together and build knowledges that can continue to expose their interconnected pasts.

Lèon, a member of l'Association des Acadien Métis Souriquois has made a commitment to learning Mi'kmaq through the building of relationships with individuals of both Acadia and Bear River First Nations. More specifically, he has developed relationships that have become close friendships and have provided him with opportunities to learn the Mi'kmaq language from Elders in Acadia First Nation. Many of these relationships have then extended beyond language-learning. Members of Métis organizations have transcended barriers and built trust among many Mi'kmaq individuals residing in the local First Nations. These relationships, sometimes initiated based on language-learning, have been beneficial to the Métis people relearning parts of their culture that were lost through assimilation and have allowed them to grow in a coexisting manner. As another participant articulated:

${ }^{34}$ Participant Interview, September 20, 2012. 
When we go to the reserve, we exchange words that have similarities and they usually have the same basic meaning! It can be very exciting for both us and the Mi'kmaq to learn the similarities our languages have. ${ }^{35}$

Alfred told me of the trust and respect that exists on Cape Sable Island. They have a close community who share and respect each other. For example, he said, "I never lock my door and I always leave my keys in my car, everybody does." He then went on to explain that it is not uncommon to have your car missing from your driveway, but sure enough, it will be back a couple of hours later. It is a community where sharing and trusting is a part of life, which, some see as coming from their Aboriginal roots, there is a sense of belonging and community and the community will help you when you are in need.

The Sou'west Nova Métis Council has extended their efforts of collaboration and respect to New England through building relations with the Mashpee Wampanoag and learning more about their ancestral past. These relations have exposed various traditions that are practiced on Cape Sable Island that can be linked to their Wampanoag ancestors. One of particular interest is the Cape Sable Easter Hut Tradition. In spring, during the time leading up to Easter, children on the Island build a teepee or wetu-style hut out of spruce and fir bush. On Easter the children take a picnic lunch of eggs, sandwiches, and sweets into the hut to eat. When this practice was explained to Dr. Herbert Waters of the Mashpee Wampanoag, and a Commissioner of Indian Affairs in Massachusetts, by Sou'west Nova Métis Council, he explained that this type of structure arose from the Wampanoag tradition of building this type of shelter during hunting, fishing and gathering expeditions. The lunch of boiled eggs in this springtime tradition stems from

${ }^{35}$ Participant Interview, July 20, 2012. 
the practice of harvesting eggs in the spring of the year. These traditions became blended with European Easter traditions as time went on.

The Aboriginal exhibition at Shelbourne's Founder's Day Festival demonstrated the importance of coexistence between the Métis and Mi'kmaq with members of Sou'west Nova Métis Council and member of the Native Council of Nova Scotia. Members of Sou'west Nova Métis Council emphasized the importance of working with local members of the Native Council of Nova Scotia as Aboriginal peoples and building a relationship of coexistence and respect. This rebuilding of relations also extends to within each family faced with the deep history of this colonial past. Although there were moments of confrontation between the Métis, the Mi'kmaq, the researcher and the people participating in the event due to varied opinions on the Métis and mixed-blood in Nova Scotia, there was an overall environment of respect. Despite some of the Mi'kmaq at the event seeming uneasy about the direction of my research, they gifted me with a small deer hide craft at the end of the festival.

The relationships that the Métis have been able to foster through their explorations into their mixed-blood and interactions with the Aboriginal groups from which their bloodlines have been beneficial. Their ability to develop these relationships is based on the mutual respect that all parties consider themselves Aboriginal, be that Métis, Mi'kmaq or Wampanoag. The Mi'kmaq peoples are not very keen on the word Métis being used in Nova Scotia, due to their own mixed-blooded histories, but they do find a common ground with the use of the term Aboriginal because it raises less contention. It also allows the Mi'kmaq and other Métis to learn the cultural similarities that they may not have known or existed between the various peoples. 


\section{Colonialism and Denial}

This section examines the impact that colonialism has played in the lives of the Métis in Nova Scotia and further examines the racism that they experienced and continue to experience, resulting in the denial of their Aboriginal roots. Many of the participants' ancestors dealt with their Aboriginal roots by "sweeping them under the carpet" as one participant stated. The colonial environment and the representation of Aboriginal Peoples as "Others" in Canada created an increased denial among the Métis in Nova Scotia to not identify as Métis publically or, in some circumstances, to no longer possess the knowledge of their historic mixed-blood.

Richardson (2006) and Lawrence (2004) describe this type of response to racism and colonialism as a "defense mechanism" that many Métis and mixed-blooded individuals use to cope with their identities in white society. The Mi'kmaq were faced with insurmountable hardships from the British. One of particular note was the bounty placed on Mi'kmaq scalps by the British in the seventeenth century. Acadians were also being scalped during this period of time because of their close relations to the Mi'kmaq (Paul 2000). Furthermore, according to informants on Cape Sable Island, their ancestors lived in fear of being scalped as well, due to their mixed-blood. Living in British controlled Nova Scotia meant living in fear of the blood one possessed, and if fitting in was possible, disguising oneself as European was a safer option for many.

There is increased evidence of discrimination toward those of mixed-blood as some Acadians and Mi'kmaq moved from Nova Scotia to Île Royale during the implementation of the Treaty of Utrecht (Basque, 2004). Jonah (2010) describes the lives 
of two Métis women living in Île Royale during this period. Through historical documentation at the Fortress of Louisbourg, Jonah (2010) was able to trace the lives of these two Métis women of Mi'kmaq and Acadian mixed-blood and the hardships they faced. Marie Josephe Le Borgne de Belîle was from Pentagouët (located in present day Maine) moved to Louisbourg to live with her aunt and uncle to increase her chances of marriage and prestige due to the urban nature of Louisbourg (ibid). Her aunt and uncle employed her as a servant, however, she was not a typical servant in Louisbourg; she was not paid and was neither fully Mi'kmaq nor Acadian (ibid). This resulted in her experiencing discrimination from the other servants as well as the inhabitants of Louisbourg.

The second woman, Marguerite Guédry, was the granddaughter of Philippe Mius d'Entremont. She was from Mirliguéche, which was in close proximity to the Acadian settlement of Le Hève, present day LaHave in the Southwestern region of Nova Scotia. She moved to Île Royale and was married to a French officer. Her husband had been forbidden to marry her as it was discovered that she had mixed-blood. Many witnesses at the wedding spoke of this mixed heritage and the fact that her mother was a "savage" (Jonah, 2010), this likely due to the wide knowledge of Philippe Mius d'Entremont's marriage to a Mi'kmaq woman.

\section{On parle pas de cela}

A quote that has stuck with me throughout this study as been, "on parle pas de cela." Anthony described this as his grandmother's response to any of his questions about their family's Aboriginal roots. This theme of "not talking about it" was dominant among the three Métis groups I worked with in this study. There was a strong sense of denial of their 
blood, their heritage and of who they are. Many were frustrated with their family's response of denial because they are proud of their Aboriginal roots and feel a sense of cultural loss associated with the denial.

During CAP's Powley Implementation Project's analysis of what the report refers to as the "Acadian-Métis" it was determined by Stephen Augustine that it is very likely that the Acadian-Métis were faced with the desire to reject their native roots and benefit from blending into white culture (CAP PIP, 2008). Richardson (2006) states that, "for the Métis, passing meant presenting oneself as either White or First Nations in order to escape being socially ostracized." (61) This is similar to what Daniel Paul argues as evidence for no Métis presence in the Maritimes, as he stated that there was no Métis because those of mixed-blood would have been raised in either Acadian or Mi'kmaq cultures. When in actuality, the Métis could have been attempting to save themselves and their families from further oppression. However, choosing to present themselves as White or First Nations does not necessarily mean that their cultures were lost, as Richardson (2006) explains; many Métis continued to practice their culture underground.

Richardson (2006) describes this concealment of Métis identity as a tactical response to discrimination. Similarly, Lawrence (2004) describes the "unsafety" that lies in 'Nativeness' and that mixed-blooded individuals are faced with the assimilatory desire to embrace white culture. Members of the Kespu'kwitk Métis Council and l'Association des Acadien-Métis Souriquois emphasized that there was much racism and hostility present from the English in Southwestern Nova Scotia for them being French. The English municipality of Yarmouth separates Clare and Argyle, both French municipalities. As Yarmouth served the area as an industrial centre, many French 
speakers experienced discrimination when seeking employment. One participant recounted a sign he once saw, reading "Acadians and Mi'kmaq need not apply." Another participant stated, "Being an Acadian was bad enough, why would be talk about being Native on top of that?"36

In this line of thought, it is not surprising that the Métis in the Maritimes would identify publically as Acadian, and mask their Aboriginal heritage and history from the predominantly English and Caucasian population. Presenting themselves as Acadian would have alleviated these hardships. As Ross and Deveau (1992) state, there was much hostility toward the Acadians upon their return the Atlantic Canada after the Proclamation of 1692, as all who were returning and resettling were French speaking Catholics and the dominant population were English speaking Protestants.

In terms of this discrimination, the Mi'kmaq were experiencing increased hardships at that time and the Acadians who possessed Aboriginal heritage would have been further oppressed if they made their identity evident at that time (ibid). Lee Ann described her mother as portraying her identity as French, from France, without any attachment to the colonial history, but was clearly in denial. She believes that denial today could stem from everything that is not in line with what is seen as Acadian today, English is bad, native is bad, black is bad and they don't necessarily want to be associated with the negative qualities of the native race, and possess an idea of ethnic purity. Lawrence (2004) describes similar experiences among urban Native populations in Toronto, describing it as, " responses of urban mixed-bloods to pressures of living in a white supremacist society" (Lawrence, 2004:120).

\footnotetext{
${ }^{36}$ Participant Interview, August 26, 2012.
} 
Some participants described the experience of identifying as Métis as something their families had difficulty accepting, particularly those of older generations. Lawrence (2004) describes mixed-blooded individuals as commonly struggling with family indifference and resistance when making claim to their aboriginal identity. Doug recounted a story about how his mother had completely cut out her colonial past. There was little acknowledgment of the struggles they faced as Acadians, let alone the fact that they had Aboriginal roots: "She was in such denial she had a picture of the Queen hanging in the living room!" he exclaimed, "She did not want to talk about it.",37

Similar to this, Art from Sou'west Nova Métis Council explained that his grandmother would wear white powder on her face to church on Sundays in order to look less dark in fear of discrimination from other members of the congregation. Lawrence (2004) describes Aboriginal people faced with this re-identification with their "Nativeness" as having to fight against what they had known as their history that their families had actively resisted or hidden from the dominant society. These defense mechanisms enabled the Métis to deny their Aboriginal blood and heritage and push their cultures further and further from the public eye.

\section{Rebuilding Relations}

In mid-August, 2012, I set out on a 3-day trip to LaHave, one of the early settlements of the Acadians, to attend the annual Mi'kmaq-Acadian Festival. The goal of this festival was to reunite the two cultures and rebuild the strong friendship of the past. As I wondered the site of Fort Sainte Marie de Grace before the festival began there were various aspects of both cultures that caught my attention, plaques explaining the

\footnotetext{
${ }^{37}$ Participant Interview, August 26, 2012.
} 
significance of this site to the early Acadians and a teepee in the distant field. Thoughts of the early colonial environment came sweeping through my mind as I wondered further towards to shore and more visitors began to arrive.

As I walked and absorbed the environment, two women, both Mi'kmaq, stood at the base of the flagpole near the main building. Before I could take a second look, the Acadian and Mi'kmaq flags were being hoisted together up the flagpole flying in the strong wind coming off the Atlantic. The image of the two flags together was a strong one and at the foundation of the meaning behind this festival (See Figure 9).

\section{Figure 9: Flags at Mi'kmag-Acadian Festival, LaHave, Nova Scotia}

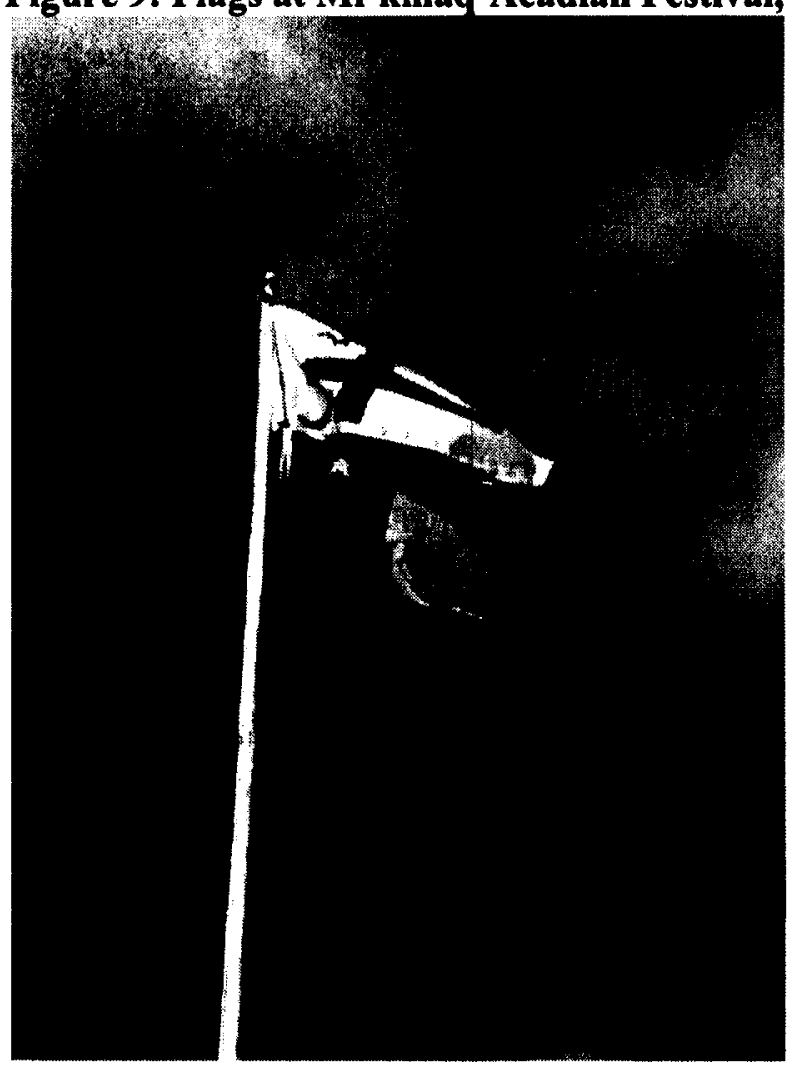

An event that holds similar goals as Mi'kmaq-Acadian Festival in LaHave, is the Acadian-Mi'kmaq Friendship Day held at Kejimukumik National Park and Historic Site. 
Ken, an Acadian, was involved in the organization of the event. He noted the importance of the relations between the populations, and the importance Kejimukumik has for both Acadians and Mi'kmaq; yet he also elaborated upon the difficultly of highlighting this importance in a government controlled environment. However, Ken and Métis individuals noted the significance of the historic relationship and the deep attachment to the Mi'kmaq culture that the park venue provides to the many who participate in the event.

Both of these events - the Mi'kmaq-Acadian Festival and the Acadian-Mi'kmaq Friendship Day — are exemplary in their efforts to develop a relationship of mutual respect and coexistence not only between the Mi'kmaq and Acadians but also for those in general attendance. As I was speaking to a member of l'Association des Acadien-Métis Souriquois at the Mi'kmaq-Acadian Festival, he pointed out some members of the Sou'west Nova Métis Council across the field. I excused myself and went to see them, all of whom I had met previously. I was not expecting to see members of this group at the festival, as they are not attached to the French or Acadian lines of Métis descent in the province.

Members of Sou'west Nova Métis Council seemed to be enjoying themselves, one member, Roger, was even giving a workshop on Mi'kmaq crafts, explaining the birch bark canoe that he had constructed by hand and was in the process of making a moose call. Tim explained that it didn't really matter to them that it was a festival that catered more to the French heritage because they were all Aboriginal and they were there to support the festival. Mi'kmaq who I had previously met at the Shelbourne Founder's Day Festival were also there selling Mi'kmaq crafts. At the end of the two-day festival there 
was a feast. The feast incorporated an array of food from the various cultures and drew a significant crowd. They roasted a lamb over the fire, served moose meat, chowder, and râpure. It was a feast that brought the people together in a way that they would have come together in the past.

These festivals served as something of an admission of the importance of the historic friendship the two cultures shared in the past and something they wish to recreate. This coming together of two cultures incorporates the fact that they are no longer denying their historical relations and past friendships; that there is increased acceptance of the Métis groups; and that new relations are possible and can grow in future generations. Events such as those described above and relation-building efforts among individual Métis and First Nations are working against the denial of their colonial past and identities to create a new found pride in their Aboriginal heritage and strong relationships of coexistence.

\section{Conclusions}

The above themes have demonstrated that the Métis in Nova Scotia have cultural links to the early métissage of the province. These linkages to mixed ancestry can be seen through genealogy, language and hunting, fishing and gathering practices that the Métis have preserved over time despite centuries of colonial denial. Through the themes there is the continuous link of métissage in Nova Scotia despite the term Métis never being present in the province. As discussed in Chapter 2, there is an importance of oral histories in Métis identity exploration and ethnogenesis; the themes presented in this chapter 
demonstrate the importance of oral history to Métis identities in the Maritimes to illustrate their contemporary attachments to their historic mixed-blood.

In the following chapter I will examine this evidence of métissage through a discussion of the categorization of Métis in Canada. It considers how a restorying of Métis identities through oral histories may allow Métis in Nova Scotia to fight against the preconceived categories being imposed upon them by the Government of Canada. Lastly, it will expand upon material discussed in Chapter 2 on the Métis' inability to gain recognition due to the constraints of the Powley Test and Canadian Case law definitions of community and collective. 


\section{Chapter 4: Categorization of Métis Identities in Nova Scotia}

In this chapter I will address the categorization of Aboriginal identities in Canada and how these categories affect the Métis in Nova Scotia. I examine the definition of Métis as defined by the Canadian State and how Métis in Nova Scotia have adopted this term in order to meet the standards of governmental categories. I will also address the way in which the concept of "community" and/or "collective" has been taken up in law and by the State to create a variable category of what constitutes Métis and how this creates further challenges for the Métis in Nova Scotia in their attempts to meet these standards.

Questions of authenticity arise around Métis identities in Nova Scotia due to the simple fact that the category of Métis was not used in the province in the past. These questions of authenticity are based on the assumption that the Métis identities have developed in order to gain hunting, fishing and harvesting rights rather than the Métis developing cultures and identities of métissage over time.

As demonstrated in the ethnographic material presented in Chapter 3, there is evidence of cultures and identities in Southwestern Nova Scotia that exhibit a high degree of métissage and cultural indications that correlate to what has been historically viewed as Métis in Canada. The Métis in this study all demonstrated their connection to their Aboriginal roots in Nova Scotia, and while the term Métis is relatively new to the province as a category, it has historic roots in the region as both a culture and an identity. 


\section{"Métisness" in Nova Scotia}

The problematic issue with recognizing Métis identity development in the Maritimes is that the printed historical record is next to nonexistent and the Canadian government relies on this historical record to create and control categories of Aboriginality. Métis identities have been historically designated by White society through discriminatory categorizations such as "half-breed," and have been externalized from "Indianness" by law and the government (Lawrence, 2004; Macdougall, 2006).

Governmental categorization of Aboriginal Peoples is problematic as a whole in Canada. This political-legal construction of Aboriginal identities distances them from cultural practices and community and allows the colonial system to gain further control (Alfred \& Corntassel, 2005). Section 35(2) of the Constitution Act 1982 lumps Indians and Métis into the same category of Aboriginal Peoples as a constitutional definition.

Boldt (1993:82) notes:

By equating the constitutional status and rights of Indians with those of the Métis ('Canadians') the governments of Canada have created the 'vagueness' that opens the door for the courts to bring Indians into conformity with prevailing federal and provincial constitutional mandates.

These governmental categories and their associated regulations on Aboriginal identity in

Canada, in fact, have been set in order to impose legal parameters upon Indigeneity (Lawrence, 2004). The way Indians and Métis were categorized in Section 35(2) of the Constitution Act 1982 was through racial indicators rather than cultural ones; this created an increased racism towards Indians and Métis from Canadians (Boldt, 1993).

This history of categorization of Aboriginal Peoples as the Other result in Aboriginal Peoples in Canada falling into a relationship of self-determination of what 
Asch (2001) describes as the 'oppositional other.' This relationship is determined under the terms of the state rather than that of the 'relational other' which would involve selfdetermination through "a conversation with respect and dignity" (Asch, 2001: 206).

Smith (1999: 34) elaborates further on this point:

History is also about power. In fact history is mostly about power. It is the story of the powerful and how they became powerful, and then how they use their power to keep them in positions in which they can continue to dominate others. It is because of this relationship with power that [Aboriginal Peoples] have been excluded, marginalized and 'Othered'.

As long as the government continues to control the category of Métis and the Supreme Court of Canada along with Provincial Courts deny the history of the Métis in the Maritime Provinces, the Métis in Nova Scotia will continue to be excluded and Othered. This identification of Aboriginal Peoples by the state is part of the imposition of an 'internalized' racist recognition (Courthard, 2007: 443), creating what Taylor (1994) would, in fact, argue are identities formed by the misrecognition of Others.

The Métis in Nova Scotia, as seen in my ethnographic data, continue to fight for their identities as Métis in Canada. Placing an emphasis on the reconstruction of colonial views of Aboriginal histories allows an Aboriginal group to reclaim their history as a source of power and use it to fight further injustices they may face in the contemporary situation (Smith, 1999). Alfred and Corntassel (2005) contend that being Indigenous comes with a conscious effort to regenerate one's Indigeneity and assert selfdetermination in the context of contemporary colonialism. The Métis in Nova Scotia are re-exploring their histories and genealogies to determine where they fit into the wider Aboriginal landscape in Canada. 
The restorying of Métis histories is allowing them to remove themselves from the colonial discourse and represent their cultures and identities in Nova Scotia without ever having to refer to themselves as Métis. According to Corntassel et al. (2009) this is part of a larger post-colonial project that questions the imposition of colonial histories on Aboriginal communities in Canada. For Métis all across the country, the restorying of their histories is allowing them to challenge western histories and governmental categories, increasing both individual and collective recognition—as seen in the recent Supreme Court of Canada decisions examined in Chapter Two of this thesis.

More particularly, however, members of the Kespu'kwitk Métis Council and l'Association des Acadien-Métis Souriquois in Nova Scotia asserted that they had been categorized as Acadians. The Sou'west Nova Métis Council argues that they had been excluded from the category of Métis because of their seclusion on Cape Sable Island up until 1910. Brown and Riley (2005) also noted the remote location of Southwestern Nova Scotia could have played a role in the Métis going unnoticed. Their Aboriginal identities have not been (re)constructed to fit the recent criteria of Métis in Canada; their Aboriginal identities have existed and developed throughout settler history, and it is only recently that they have placed themselves within the pre-constructed categories of the government in order to gain the State's recognition as Aboriginal Peoples. The same identities that their ancestors may have hidden from the public eye due to racism and the colonial environment are now identities in which they find pride and belonging and are seek recognition for.

Many of the participants I interviewed stressed that they viewed themselves as Aboriginal, but Métis was the category that fit their identities in Nova Scotia. Many 
found the term problematic, not in that they did not identify with what the category of Métis in Canada means, but rather it was just a word to describe what they already described themselves as, such as a Cape Islander, an Acadian, or French; it was, as one participant put it, "a buzz word".

These categories and how they are constructed are ultimately preventing the Métis in Nova Scotia from gaining recognition, simply due to the fact that the Powley Test as a means of categorization proves these identities improbable in the region of the Maritimes. Furthermore, Métis have been legally excluded from "Indianness" in Canada, they have, in a way, been forced to pursue "Métisness" rather than "Indianness" creating a narrower category that is distinct from other Aboriginal Peoples (Lawrence, 2004: 101). Lawrence (2004: 14) sees governmental categories and definitions "in the context of a colonizing culture, [where] any concern with settling boundaries to Indianness is inevitably shot through with legal definitions and notions of Indianness originating in the dominant culture."

What cannot be overlooked is an increased pride in their heritage and a need for the Métis to restory their histories in a process of truth-telling. The increased exposure of truth about Métis identities and bloodlines in Nova Scotia will support greater recognition of Aboriginal ancestry and decrease discrimination and denial surrounding these genealogies. As Eleanor stated, "People are really fier... proud, to be an Acadian, it's a good day to be an Acadian so why mess it up. I'm an Acadian but I'm Métis, but like I said I'm proud." ${ }^{38}$

${ }^{38}$ Participant Interview, July 26, 2012. 


\section{Community or Collective?}

As stated in Chapter Two, the concept of "community" is a major aspect of the Congress of Aboriginal Peoples' (CAP) Powley Implementation Project. The terms community and collective have been used interchangeably and the distinction between the two have not been properly addressed in $R$. v. Powley (Lombard, 2007: 8). This poses important questions: What is community to the Métis in Nova Scotia? Can it be viewed in terms of a collective rather than a land based community?

Geographical boundaries that the Court calls a "community" or a "site" are boundaries that can be seen as relatively arbitrary to those involved in their creation. The creation of land-based communities is limiting when looking at the case of the Métis in Nova Scotia. The Métis in Nova Scotia do not limit their membership to a specific geographic location; they adopt the concept of the imagined community (Anderson, $2008)$ to reach out to their members in other parts of the province, country and world.

This diasporic sense of community is necessary to the Métis in Nova Scotia as their identities have been marginalized and dispersed. In federal government reports on Métis in Nova Scotia there was a lack of attention paid to collective Métis perspectives in the analysis of historical records (CAP PIP, 2008), which could have contributed to this wider collective of Métis in Nova Scotia. Constitutional documents and Canadian law create a contemporary colonial boundary for Métis recognition in the Maritimes. This leaves the Métis in Nova Scotia trying to create something for the government and for the court because of legislation that stipulates that Métis collective identity is determined though a land-based community. 
With the categories that existed during the colonization of Nova Scotia, the Métis comminutes became disregarded and miscategorized. L'Association des Acadien-Métis Souriquois draw on the strong collective identity of the Acadians as evidence of a Métis community as they see the Acadian community as the Métis community. The identity of the Acadian was strong, and ultimately shaped the identity of francophone Nova Scotia. This identity was redefined and reinvented post-deportation and during the course of the Acadian Renaissance where cultural symbols and pride were generated (Thériault 1982; Biddiscombe 1990; Stanley 1981). There are Acadians dispersed throughout the Maritime Provinces, yet they still possess the same strong Acadian identity.

Similarly, the Kespu'kwitk Métis Council is approaching their identities though a collective, imagined community as well. When asked about membership during the Senate Meetings on Métis recognition, they responded:

It does not matter where they live, as long as their genealogy is perfect. We have membership right across Nova Scotia. We have many people from Chéticamp because there is no organization up there. Most of them belong to the Kespu'kwitk Métis Council. ${ }^{39}$

Much like the mindset of the Acadian identity, the Kespu'kwitk Métis Council possess an imagined community, where its members maintain a sense of community through a collective that is not limited to a geographic community.

The isolation on Cape Sable Island could also account for them going unnoticed as Métis and the maintenance of a strong Aboriginal community. This community has a great degree of sharing and trust that is a natural part of life, which presents a sense of collective that can be likened to that of First Nations peoples. However, the building of

${ }^{39}$ Proceedings of the Standing Senate Committee on Aboriginal People: Issue 26 Evidence - November 6, 2012, Parliament of Canada. 
the causeway and their exposure to the dominant society in Barrington and area created a challenging influence and continued theme of denial of their Aboriginal identity.

Daniel Paul (2005) argues that there were no Métis communities in Nova Scotia because mixed-blooded individuals were raised in either Acadian or Mi'kmaq communities. However, Augustine (2008) notes the possibility of Métis communities simply being incorporated into Acadian communities based on linguistic similarities. This is not as simple as miscategorization, but rather that the Métis began classifying themselves as Acadian, French or Cape Islander in order to survive.

\section{Conclusions}

It becomes evident quite quickly that the oppression of the Métis identities in Canada has not been completely resolved; it continues, and the conversation of the Métis in the Maritimes in particular remains feared and slighted and therefore absent from National Métis pursuits towards recognition. Recognition becomes increasingly difficult for the Métis in the Maritimes as they are not acknowledged by the Métis National Council (MNC). In an earlier testimony to the Standing Senate Committee on Aboriginal Peoples on May 15, 2012, President of Métis National Council, Clement Cartier stated: "The courts have also ruled against claims to constitutionally protect Métis harvesting rights of mixed-ancestry groups outside our historical homeland such as those in Atlantic Canada on the grounds that there was no evidence of historical Métis communities in these 
regions. ${ }^{, 40}$ The problem with many of the Maritime Métis court cases continues to lie in the arbitrary nature of the category being used: community.

Colonial power keeps Aboriginal Peoples in subordinate and marginal positions as "Others" in Canadian society (Smith, 1999). For Métis, being Othered historically meant remaining culturally invisible to the dominant society and therefore decreasing their current abilities to prove their attachments to historic Métis communities or collectives. Through restorytelling the Métis can reform their place in the governmental categorization of Métis, community and collective, building towards the recognition of Métis in Nova Scotia. With the present ambiguity that exists in definitions and categorization, the Métis remain in a marginal position in the province and in Canada.

${ }^{40}$ Proceedings of the Standing Senate Committee on Aboriginal Peoples: Issue 18 Evidence - May 15, 2012, Parliament of Canada. 


\section{Chapter 5: Conclusion}

In $2003 R$. v. Powley changed the way Métis recognition is approached in Canada. This decision brought new hope to the self-identifying Métis in the Maritime Provinces and increased their motivation to fight for their own recognition and rights. This, along with the inclusion of Métis in the Maritimes in the recent Senate Committee Meetings on Aboriginal Peoples pertaining to Métis recognition, and the success of both Daniels $v . R$ and the Manitoba Métis Federation v. Canada in the Supreme Court in 2013, demonstrate the importance of exploring Métis identities in the country and reanalyzing histories that may have been misrepresented or overlooked by the Canadian State. These breakthroughs in Métis recognition have the potential to create major changes in the way Métis are represented, recognized and categorized in Canada.

In this thesis I sought to answer the questions: Who are the Métis in the Nova Scotia? How do they define themselves? How do they identify as Métis and why? And how is métissage represented in cultural components of identity? Through extensive research on the historical and legal complexities that attach themselves to these Métis identities, the main research findings are:

1) Métis identities have developed in Nova Scotia despite centuries of oppression and discrimination;

2) Métis are the descendants of the French Settlers and the result of the ethnogenesis of the Acadians; and the long lost descendants of the New England Mashpee Wampanoag, all of whom had strong relations and intermarriage with the Mi'kmaq Nation in Nova Scotia; and

3) There is strong evidence of a continued presence and maintenance of the vast intricacies of the historic métissage that occurred during the early colonization of the province. 
The assertion and self-determination of these Métis continues to provide opportunities for restorytelling and reassertion of distinct Aboriginal identities in Nova Scotia; ultimately challenging the miscategorization and repression of Métis in this region for almost three hundred years. This retelling of their history has provided them with the power to take pride in their identification and combat settler histories with their own oral histories. Through membership and genealogy, the Métis in Nova Scotia have been able to demonstrate their evidence of mixed-blood and sense of belonging as Aboriginal peoples. The wide-ranging similarities that exist between Aboriginal languages and dialects used by the Métis in Nova Scotia presents evidence of métissage and pathways to build stronger relationships with both Aboriginal and settler populations.

These identities also allow the Métis to remain deeply engaged with their environmental surroundings and provide a means to pass their knowledge of the land, animals and waters on to future generations of Métis in the province. Furthermore, this identity presents them with the opportunity for future struggles as they continue to live in a colonial environment that challenges their identities as Aboriginal Peoples. Nonetheless, they have overcome many obstacles in terms of colonialism and denial and the linkages that have been drawn between their self-determination and cultural métissage. This has given them more reason to fight for what they believe they deserve, not only for themselves, but also for generations to come.

These populations have, through strategic systems of denial and silence, been able to survive and retain aspects of their cultures. Richardson (2006) notes that many Métis across Canada strategically hid their identities from mainstream society in order to minimize racism, yet continued to practice their culture underground. As illustrated in 
this thesis, the Métis in Nova Scotia used similar survival techniques and also practiced their culture underground. In some cases, this cultural continuation was not even known to the Métis individual before their discovery of their Aboriginal roots, or was masked by other cultural and/or ethnic labels.

Through history, legal struggles and cultural indications of métissage, the Métis of Nova Scotia find themselves in a category that is not widely accepted. Publicly identifying as Métis or learning about their Aboriginal roots has provided Métis in this study with a strong sense of personhood and a sense of collective belonging in Canada; however, they continue to find themselves in conflict with other populations, other Métis in Canada and the provincial and federal governments. Eddie, a Mi'kmaq man, expressed his concern for the Métis movement in Nova Scotia as he noted that they're going to have a long road ahead of them because of the way the provincial and federal governments operate in regard to Aboriginal issues in Canada. However, this does not seem to worry any of the Métis in Nova Scotia. Their main concern is with governmental recognition of who they are.

Through building relationships at the local level, such as, between Métis organizations themselves, increased relations with the Mi'kmaq, Acadians and Métis in other provinces, the Métis in Nova Scotia will be able to increase their recognition through relationships built on respect and coexistence. Tully (1995) stresses the importance of public recognition to an identity, especially when various peoples are living within one polity. Without this recognition they will continue to be in an 
oppositional relationship with the state and Othered through governmental categorization (Asch, 2001).

Through their increased visibility in Southwestern Nova Scotia, joint with their relationship building efforts, these Métis have begun the steps to reach national recognition. In steps to come, I believe there will need to be increased cooperation between the various Métis groups in the province in order to present themselves and their common goals to the provincial and federal governments. Many participants voiced this as a concern, since the groups do stand divided on some issues, the government does not seem to take them seriously.

I suggest the development of larger collective organization that would address the common goals of the organizations and represent them from a provincial level, a Nova Scotia Métis Nation. This type of structure would allow them to operate in similar ways as Métis in other provinces and create more cohesive relationships with the Métis at the National level as well as with the Government of Canada. This suggestion is not to say that the groups should merge into one organization nor would they need to agree on all issues, but having collective representation from all Métis organizations in the province would allow them to have collective voice on issues they share and have a stronger stance in the eyes of the government.

In addition, as the groups continue to promote their efforts within the province, they will continue to educate and increase the awareness of their movement. This increased awareness will make their presence known and continue to combat the negative perceptions of their cultures. As they continue to work with other populations in the region they will continue to harbor relations of mutual respect and coexistence in the 
province. Moreover, the genealogical and DNA research that is being undertaken within the groups and by others will continue to present validity in their movement and bring them closer to recognition in tandem with their oral histories of métissage.

This research has contributed to the expanding knowledge of Métis identities East of Ontario. It has the potential to impact policy and legal cases that pertain to the Métis identities in Nova Scotia. It also presents a case for the need and importance of ethnography in looking at contemporary Métis identities in Canada. This method of data collection has a potential to bring oral histories into the existing literature on Métis identities in the Maritimes Provinces. This research has also filled gaps in the literature; first, it addressed the histories and traditions of the Sou'west Nova Métis Council, or the Nova Scotia Wampanoag, who had been excluded from all other studies on the Métis in Nova Scotia. Furthermore, this study has provided a more detailed anthropological account of oral histories of the Métis in Nova Scotia and how they situate themselves along with the comparative voices of the Mi'kmaq and the Acadians.

For future research on this topic, it would be worth exploring each individual organization and its members in more detail to present the oral traditions and other complexities that were outside the scope of this research project. It would also be important to consult with the Eastern Woodlands Métis Nation, who did not participate in this project. Moreover, these identities extend into New Brunswick, Prince Edward Island, Newfoundland and Labrador and the Gaspé Peninsula and these regions could add another level to the data presented here. In addition to the Maritime Provinces, there are members of l'Association des Acadien-Métis Souriquois and Kespu'kwitk Métis Council who reside in New England and the Southern United States. These members represent 
descendents of those exiled during the Acadian Deportation; exploring these identities could provide another substantial degree of complexity to this topic.

Self-identification as Métis in Canada comes with struggle. This historically derived identity throughout Canada has been subject to discrimination and Othering, not only from settler society, but also from Aboriginal Peoples. There is more to learn about these complex identities and this will not be the last we hear from the Métis in Nova Scotia. However with the continuously changing environment concerning Aboriginal issues in Canada, the Métis in the Maritimes have become increasingly more aware of themselves and where they fit within prescribed categories. Their struggle now lies in collective recognition as Métis in Canada, although they face discrepancies in terms of categories and definitions in both law and government, they have the will to fight and the right to find a place to belong in Canada. 


\section{Bibliography}

Alfred, T. \& Corntassel, J. (2005). Being Indigenous: Resurgences against Contemporary Colonialism. Government and Opposition, 40(4), 597-614.

Anderson, B. R. O. (2008). Imagined communities: Reflections on the origin and spread of nationalism (Rev ed.). London; New York: Verso.

Anderson, D. (2004). Raindeer, Caribou and 'Fairy Stories' of state power. In D. Anderson and M. Nuttall, (Eds.). Cultivating Arctic landscapes: Knowing and managing animals in the circumpolar North. New York: Berghahn Books.

Asch, M. (2001). Indigenous Self-Determination and Applied Anthropology in Canada: Finding a Place to Stand. Anthropologica, 43(2), 201-207.

Augustine, S. (2008). Congress of Aboriginal Peoples Powley Implementation Project: Métis in Atlantic Canada. Phase Three Report. (February 15, 2008).

Basque, M. (2004). The Third Acadia: Political Adaptation and Societal Change. In, The 'Conquest' of Acadia, 1710: Imperial, Colonial, and Aboriginal Constructions, (Ed.) J. Reid, M. Basque, E. Mancke, B. Moody, G. Plank, \& W. Wicken. Oxford: Oxford University Press.

Beal, B. \& R. C. Macleod. (1984). Prairie fire: the 1885 North-west Rebellion. Edmonton: Hurtig.

Bell, W. P. (1990). The foreign Protestants and the settlement of Nova Scotia: The history of a piece of arrested British colonial policy in the eighteenth century. Fredericton: Acadiensis Press.

Biddiscombe, P. (1990). Le tricolore et l'étoile: The Origin of the Acadian National Flag. Acadiensis 20:1, pp. 120-147.

Brown, J. S. H. (1980). Strangers in blood: fur trade company families in Indian country. Vancouver: University of British Columbia Press.

Brown, K. \& Riley, A., Public History Inc. (2005). Historical Profile of the Southern Nova Scotia Area's Mixed European-Indian Ancestry Community. Draft prepared for the Department of Justice Canada.

Brun, R. (2003). Les Acadiens Avant 1755: Essai. Moncton: Regis Brun.

Boldt, M. (1993). Surviving as Indians: The challenge of self-government. Toronto: University of Toronto Press. 
Borrows, J. (2010). Canada's indigenous constitution. Toronto: University of Toronto Press.

Boyden, J. (2010). Louis Riel and Gabriel Dumont. Toronto: Penguin Group.

Campbell, M. (1982). Halfbreed. Lincoln: University of Nebraska Press.

The Canadian Press. (2013, February 6). Métis, non-status Indian ruling to be appealed. The Canadian Press.

Caplan, R. (2004). Acadian lives in Cape Breton Island. Wreck Cove: Breton Books.

Chute, J.E. (1998). Mi'kmaq fishing in the Maritimes : a historical overview. In Earth, water, air and fire: studies in Canadian ethnohistory, (Eds.) D. McNab.

Coates, K. (2003). Breathing New Life into Treaties: Hisotry, Politics, the Law and Aboriginal Grievances in Canada's Maritime Provinces. Agricultural History, 77(2): 33-354

Congress of Aboriginal Peoples (April, 2008). Final Powley Implementation Project Report (2007-2008).

Congress of Aboriginal Peoples (May 2007). Powley Final Report 2006-2007. Volume 1.

Corntassel, J., Chaw-win-is, \& T'lakwadzi (2009). Indigenous Storytelling, Truth-telling, and Community Approaches to Reconciliation. ESC, 35(1), 137-159.

Coulthard, G.S. (2007). Subjects of Empire: Indigenous Peoples and the 'Politics of Recognition' in Canada. Contemporary Political Theory, 6, 437-460.

Devine, H. (2004). People who own themselves: aboriginal ethnogenesis in a Canadian family, 1660-1900. Calgary: University of Calgary Press.

Elliot, D. (2005). Law and Aboriginal People in Canada. Concord: Captus Press.

Faragher, J. M. (2005). A great and noble scheme: The tragic story of the expulsion of the French Acadians from their American Homeland. New York: W.W Norton \& Co.

Fischer, D. H. (2009). Champlain's dream. Toronto: Vintage Canada.

Gould, G. P., \& Semple, A. J. (1980). Our land: The Maritimes : the basis of the Indian claim in the Maritime provinces of Canada. Fredericton: Saint Annes Point Press. 
Griffiths, N. E. S. (2005). From Migrant to Acadian: A North American Border People, 1604-1755. Montreal: McGill-Queen's University Press.

Griffiths, N. E. S. (1992). The Contexts of Acadian History, 1686-1784. Montréal: McGill-Queen's Press.

Handler, R. (1988). Nationalism and the politics of culture in Quebec. Madison: University of Wisconsin Press.

Hautecoeur, J. (1976). Nationalisme et developpement en acadie. Recherches Sociographiques, 17(2), 167-188.

Ingold, T. (2000). The perception of the environment : Essays on livelihood, dwelling and skill. London; New York: Routledge.

Iseke-Barnes, J. (2009). Grandmothers of the Métis Nation: A Living History with Dorothy Chartrand. Native Studies Review. 18(2): 69--104

Jobb, D. (2005). The Acadians: A People's Story of Exile and Triumph. Mississauga: J. Wiley \& Sons Canada.

Jonah, L.A.M. (2010). Unequal Transitions Two Métis Women in Eighteenth-Century Ile Royale. French Colonial History, 11(1), 109-129.

Krech, S. (2005). Reflections on conservation, sustainability, and environmentalism in indigenous North America. Peace Research Abstracts Journal, 42(5), 78-86.

Ladner, K. \& Dick, C. (2008). Out of the Fires of Hell: Globalization as a Solution to Globalization - An Indigenist Perspective. Canadian Journal of Law and Society, 23(1-2), 63-91.

Landry, P. (2007). The lion and the lily: Nova Scotia between 1600-1760. Victoria: Trafford.

Lassiter, L.E. (2005). Collaborative Ethnography and Public Anthropology. Current Anthropology, 45(1): 84-103.

Lawrence, B. (2004). Real Indians and Others: Mixed Blood Urban Native Peoples and Indigenous Nationhood.

Lombard, A. (March 12, 2007). Post-Powley Case Analysis: Final Report March 2007, for the Congress of Aboriginal Peoples National Powley Implementation Project.

MacDonald, M. A. (2000). Fortune \& La Tour: The civil war in Acadia. Halifax, NS: Nimbus Pub. 
Macdougall, B. (2010). One of the family: Metis culture in nineteenth-century northwestern Saskatchewan. Vancouver: UBC Press.

Made-In-Nova-Scotia Process. (2002). Agreement between the Mi'kmaq, Nova Scotia and Canada. Retrieved from: http://www.gov.ns.ca/abor/docs/FrameworkAgreement.pdf

Mancke, E, \& Reid J. (2004). Elites, States and the Imperial Contest for Acadia. In, The 'Conquest' of Acadia, 1710: Imperial, Colonial, and Aboriginal Constructions, (Ed.) J. Reid, M. Basque, E. Mancke, B. Moody, G. Plank, \& W. Wicken. Oxford: Oxford University Press.

More, J. F. (1873). The history of Queens County, N.S. Halifax: Nova Scotia Print. Co.

Nadasty, Paul. (2007). "The gift in the animal: The ontology of hunting and humananimal sociality." American Ethnologist 34(1): 25-43.

Nagel, J. (1995). Americaan Indian Ethnic Rewnewal: Politics and the Resurgence of Identity. American Sociological Review, 60(6): 947-965.

Native Council of Canada and Daniels, H.W.(1979). The Forgotten people: Metis and non-status Indian land claims. Ottawa: Native Council of Canada.

Naraya, K. (1993). How Native Is a "Native"Anthropologist? American Anthropologist, $95,671-686$

Nickels, B. (2001). Native American free passage rights under the 1794 Jay Treaty: Survival under United States statutory law and Canadian common law. Boston College International and Comparative Law Review, 24(2), 313-339.

O'Toole, D. (May 23, 2005). Métis Section 35 Rights: Underlying Principles of Constitutional Communities in the supreme Court of Canada Case Law, for Congress of Aboriginal Peoples: Powley Implementation Project.

Paul, D. N. (2005). Maritime Métis? Or Opportunists? Retrieved from: http://www.danielnpaul.com/Col/2005/SamuelDeChamplainMi'kmaq Greeting.html

Paul, D. N. (2000). We were not the savages: A Mi'kmaq perspective on the collision between European and native American civilizations. Halifax, N.S: Fernwood.

Plank, G. (2003). Unsettled Conquest. Philadelphia: University of Pennsylvania Press

Reid, J. G. (2004). The "conquest" of Acadia, 1710: Imperial, colonial, and aboriginal constructions. Toronto: University of Toronto Press. 
Reimer, G. and J.P. Chartrand. (2004). Documenting Historic Métis in Ontario. Ethnohistory, 51:3, 567-607.

Rich, E. E. (1967). The fur trade and the Northwest to 1857. Toronto: McClelland and Stewart.

Richardson, C. (2006). Metis Identity Creation and Tactical Responses to Oppression and Racism. Variegations (2), 56-7.

Ross, S., \& Deveau, A. A. (1992). The Acadians of Nova Scotia Past and Present. Halifax: Nimbus Publishing.

Roth, C. (2002) Without Treaty, Without Conquest: Indigenous Sovereignty in Post-Delgamuukw British Columbia. Wicazo Sa Review. 17(2): 143-165.

Rundquist, M. (2012a). Revising Anne Marie. Pennsylvania: Infinity Publishing.

Rundquist, M. (2012b). Cajun By Any Other Name. Pennsylvania: Infinity Publishing.

Rundquist, M. (2012c). C3b Y Chromosome DNA Test Results Point to Native American Deep Ancestry, Relatedness, among United States and Canadian Study Participants. C3b Y DNA Study, 1-10.

Saul, J. R. (2008). A fair country: Telling truths about Canada. Toronto: Viking Canada.

Silverman, D. J. (2005). Faith and boundaries : Colonists, christianity, and community among the wampanoag indians of martha's vineyard, 1600-1871. New York: Cambridge University Press.

Smith L.T. (1999). Decolonizing methodologies : research and indigenous peoples. New York: Zed Books Ltd

Stanley, George F.G. (1982). The flowering of the Acadian renaissance. In, Eastern and Western perspectives: papers from the joint Atlantic Canada/Western Canadian studies conference (Pp. 19-46).

Statistics Canada. (2006). Population by selected ethnic origins, by province and territory, 2006 Census. Ottawa: Statistics Canada.

Statistics Canada. (2006). Aboriginal identity population, for Canada and census subdivisions (municipalities) with 5,000-plus population -20\% sample data, Statistics Canada, 2006 Population Census. Ottawa: Statistics Canada.

Sturm, C. (2002). Blood politics: Race, culture, and identity in the Cherokee Nation of Oklahoma. Berkeley: University of California Press. 
Surette, R. F. (2004). Métis/Acadian heritage 1604 to 2004. Lower Wedgeport: Surette.

Taylor, C. (1994). The Politics of Recognition, In A. Gutman (Ed.), Multiculturalism: Examining the Politics of Recognition, (pp. 25-73). Princeton: Princeton University.

Thériault, L. (1982). “Acadia, 1763-1978." The Acadians Of The Maritimes: Thematic Studies. Ed. Jean Daigle. Moncton: Centre d'études acadiennes.

Town, F. (1998). The North West Company: frontier merchants. Toronto: Umbrella Press.

Tully, J. (2008). Public philosophy in a new key: Volume 1. Cambridge: Cambridge University Press.

Tully, J. (1995). Strange multiplicity: Constitutionalism in an age of diversity. Cambridge: Cambridge University Press.

Ugarte, R.A. \& Sharp, G. (2001). A new approach to seaweed management in Eastern Canada: the case of Ascophyllum nodosum, Cah. Biol. 42, 63-70.

Van Kirk, S. (1980). Many tender ties: Women in fur-trade society in Western Canada, 1670-1870. Winnipeg, Man: Watson \& Dwyer.

Wallis, W. D., \& Wallis, R. S. (1955). The Micmac Indians of eastern Canada. Minneapolis: University of Minnesota Press.

Weinstein, J. (2007). Quiet revolution west: the rebirth of Métis nationalism. Calgary, Alta: Fifth House Publishers.

Wicken, W. C. (2012). The colonization of mi'kmaw memory and history, 1794-1928: The king v. gabriel sylliboy. Toronto: University of Toronto Press.

Woodcock, G. (1975). Gabriel Dumont: the Métis chief and his lost world. Edmonton: Hurtig.

\section{Legal Sources:}

Castonguay and Faucher v. R., 2002 NBPC 31 (CanLII); aff'd 2003 NBQB 325 (CanLII); aff'd 2006 NBCA 43 (CanLII).

Constitution Act, 1982, Schedule B to the Canada Act, 1982 (U.K., 1982, c. 11.)

Daniels, Gardner \& Congress of aboriginal Peoples v. Canada, 2002 FCT 295; 2005 FC 1109; 2011 FC 230 (CanLII). 
Proceedings of the Standing Senate Committee on Aboriginal Peoples: Issue 18 Evidence - May 15, 2012, Parliament of Canada. Retrieved from: http://www.parl.gc.ca/content/sen/committee/411/APPA/18EV-49549-E.HTM

Proceedings of the Standing Senate Committee on Aboriginal People: Issue 26 Evidence, November 6, 2012, Parliament of Canada. Retrieved from: http://www.parl.gc.ca/content/sen/committee/411/APPA/26EV-49788-E.HTM

Teillet. J. (2004) Métis Law Summary. Toronto: Pape and Salter, barristers and solicitors.

Teillet, J. (2011). Métis Law in Canada. Toronto: Pape and Salter, barristers and solicitors. Retrieved from: http://www.pstlaw.ca/resources/MLIC-2011.pdf

The Royal Commission on Aboriginal People (1995). Perpectives and Realities, Métis Perspectives: The Other Métis. Vol. 4, Ch. 5, s. 3.

R. v. Chiasson [2004] N.B.J. No. 62 (N.B.Q.B.) (QL); leave to appeal denied 2005 NBCA 82 (CanLII).

R. v. Chiasson [2002] 2 C.N.L.R. (N.B.P.Ct.); 2004 NBQB 80 (CanLII); leave to appeal to the Court of Appeal denied 2005 NBCA 82 (CanLII).

R. v. Delgamuukw [1997] 3 S.C.R 387, 408 SCC.

R.v. Diagle, [2004] N.B.J. No.73R. v. Daigle, 2003 NBPC 4 (CanLII).

R. v. Hopper [2004] N.B.J. No. 107; [2005] NBJ No. 477 (QB); [2008] 3 CNLR 337 (NBCA).

R.v. Lavigne, [2005] N.B.J. No. 92.

R. v. Powley, [2003] SCC 43.

R. v. Powley, [1998] O.J. No. 5310 (P.Ct.).

R. v. Sparrow [1990] 1 S.C.R. 1075 (S.C.C.).

R. v. Vautour [2010] NBPC 39. MC027010.

R. v. Vautour [2001] N.B.J. No. 494. 


\section{Organizational Sources:}

AADNC. (2010). Mi'kmaq of Nova Scotia, Province of Nova Scotia and Canada Sign Landmark Agreement, Ref. \#2-3403, Millbrook, Nova Scotia (August 31, 2010). Retrieved from: http://www.aadnc-aandc.gc.ca/eng/1100100015373

L'Assocation des Acadien-Métis Souriquois. (2013). Constitution. Retrieved from: http://www.acadiens-metissouriquois.ca/uploads/3/2/0/8/3208447/aams constitution.pdf

East-West Métis Union. (2006). Recognition of New Brunswick Métis by the Métis of the West.

Métis National Council (2011). Citizenship. Retrieved from http://www.metisnation.ca/index.php/who-are-the-metis/citizenship

Sou'west Nova Métis Council. (2012). News. Retrieved from: http://nswampanoag-nsmetis.org/news.html

Tufts, P. (2009). Denied Community Rights. Retrieved from http://acadiens-metissouriquois.ca/2501/39001.html.

Kespu'kwitk Métis Council. (2012). Announcements. Retrieved from http://swnmetis.webs.com/ann.html 


\section{Appendix A: Sample Interview Questions: Métis}

1. Can you tell me about Métis culture in the East?

2. What makes Métis culture in the East distinct from Acadian and Mi'kmaq culture?

3. Why do you think it is not well known that there are Métis in the East?

4. Can you explain your attachment to your Aboriginal heritage?

5. Can you explain your attachment to your French/Acadian heritage?

6. How do you feel abut the fact that Métis in the East are not constitutionally recognized?

7. What kind of recognition do you think should be granted?

8. The Powley Test requires that: (1) There is a characterization of the right (2) There must be an identified historic rights bearing Métis community, (3) There must be an identified contemporary rights being Métis community and (4) One must possess membership in the contemporary Métis community.

Do you think the Powley Test should be applicable to the East, as it is in Ontario?

9. Can you tell me about your Métis community?

10. What is the importance of community to your people?

11. How did the Acadian deportation affect your people?

12. How did your people recover and redevelop from that experience?

13. How did it affect your ability to claim a historical community?

14. What is your connection to Métis organizations?

15. Do you think that Métis organizations are effective?

16. What is the next step for Métis recognition in the East?

17. Why do you think the government does not recognize the Métis in the East?

18. So you feel like your people are in need for federal recognition?

19. How does your language differ from Acadien and Mi'kmaq? How is it similar?

20. What cultural practices so you share with Acadians and the Mi'kmaq?

21. At what point in history would you say the Métis identity was developed? 


\section{Appendix B: Sample Interview Questions: Acadians}

1. Do you think there are Métis in the East?

2. What is the relationship between the Acadians and the Métis? the Mi'kmaq?

3. Do you think it is possible that all Acadians could be Métis?

4. Could you explain the difference between having Métis status and Aboriginal ancestry?

5. Have you ever explored your heritage? What are the aboriginal connections?

6. Have you ever tried to register as Métis with a Métis organization?

7. If yes, What organization did you work with?

8. Was your application successful? What made you pursue this process? Can you tell me about the process?

9. Do you feel Métis?

10. Do you practice Métis cultural traditions?

11. Why do you think many Acadians are not aware of their aboriginal ancestry?

12. Why do Acadians identify so strongly with their French ancestry?

13. If Métis in the East are not recognized as Métis, do you think there should be other steps taken towards recognition? If so, what do you think should be done?

14. Can you tell me about Acadian French and it's inclusion of Mi'kmaq words? 


\section{Appendix C: Sample Interview Questions: Mi’kmaq}

1. Can you speak to the shared history the Mi'kmaq and the Acadians share?

2. What do you think about the claims being made by those who identify as Métis in the East?

3. What is the Mi'kmaq relationship with/to the Métis in the East?

4. How do your histories blend with their histories?

5. What is the present day relationship between the Mi'kmaq and the Acadians?

6. How did the Acadian deportation affect your people?

7. Do you think it is possible that all Acadians could be Métis?

8. Could you explain the difference between having Métis status and aboriginal ancestry?

9. Can you speak to the Mi'kmaq influence in Acadian French?

10. Why do you think the government does not recognize the Métis in the East?

11. So you feel Métis in the Maritimes deserve federal recognition?

12. What cultural practices so you share with Acadians and the Mi'kmaq? 


\section{Appendix D: Consent form for all participants}

Title of research project: Defining Distinctness: A search for Métis recognition in the Maritimes

Date of ethics clearance: May 28, 2012

\section{Dear Sir/Madam,}

My name is Katie MacLeod and I am an Anthropology student at Carleton University in Ottawa. I am conducting research on Métis status in the Maritime Provinces and would appreciate your input as an interview participant. Interviews will last between 30 and 120 minutes at a location of your choice. Interviews will be semi-structured and will inquire about your personal feelings and experiences with Métis in the Maritimes. If you consent to me doing so, I would also like to make an audio recording of our interview.

Participating in this research poses minimal risk to participants, though your statements could lead to social, economic, psychological and/or emotional harm if they are attributable to individual persons or organizations. I am sensitive to these risks and I will implement all necessary measures to ensure your privacy and anonymity. All information you provide to me will be kept securely stored and responses will not be attributed to participants but rather attributed to pseudonyms to protect your identity. While all measures will be taken to protect your identity, if you are in a position of authority, there is a risk that your identity could be discovered, due to the nature of your position within the organization and/or community. I will be the only person will access to the data, which I will keep securely stored.

Participants may withdraw from the interview at any time, and have a subsequent window of 3 months from the date of the interview to withdraw their statements (in whole or in part). If you do choose to withdraw from the study, any information you provided to me will be destroyed. You also have the right to refuse to answer any question. When this project is completed, you will be notified as to where the results can be accessed. Data and findings will be securely stored in the student's private filing cabinet to be used for future research on this topic. If I wish to use this data for any other projects I will contact you for your permission.

Participation in this study will contribute to an increased knowledge of the history and relations in the region and existence of Métis identity in the Maritimes. Furthermore, your participation will contribute to the increased understanding of the distinct identities of the Métis, Mi'kmaq and the Acadians who are involved in these complex historically rooted relations. This research will be presented in a Master's thesis in Anthropology, articles and in conference presentations. 
This project is being conducted with faculty supervision. You may contact my supervisors with any questions or concerns.

Dr. Donna Patrick

Director, School of Canadian Studies

Professor, Department of Sociology and Anthropology

Carleton University

1125 Colonel By Drive

Ottawa, ON, Canada K1S 5B6

Tel: (613)-520-2600 x 8070 Fax: (613)-520-3903

donna_patrick@carleton.ca

Dr. Siomonn Pulla

Adjunct Professor, School of Canadian Studies

Contract Instructor, Department of Sociology and Anthropology

Carleton University

1125 Colonel By Drive

Ottawa, ON, Canada K1S 5B6

spulla@.connect.carleton.ca

This project has received ethics approval by the Carleton University Research Ethics Board. Should you have any concerns or questions about this research or our conduct, please do not hesitate to contact:

Antonio Gualtieri, Chair

Research Ethics committee

Carleton University

1125 Colonel By Drive

Ottawa, ON, Canada, K1S 5B6

Email ethics@carleton.ca

Tel: 613-520-2517

Thank you for your consideration.

Katie MacLeod, Master's candidate

Department of Sociology and Anthropology

Carleton University

1125 Colonel By Drive

Ottawa, ON, Canada K1S 5B6

Kmacleo1@connect.carleton.ca 


\section{Participant consent to interview}

I, to participate in the study as described, as well as to be audio recorded.

Signature of Participant

\section{Date}

Additional Participant (optional):

I, $\longrightarrow$, have read the above letter and voluntarily consent to participate in the study as described, as well as to be audio recorded.

Signature

Date

Student Researcher

Date 


\section{Appendix E: Oral Consent Script}

My name is Katie MacLeod and I am an Anthropology student at Carleton University in Ottawa. I am conducting research on Métis status in the Maritime Provinces and would appreciate your input as an interview participant. Interviews will last between 30 and 120 minutes at a location of your choice. Interviews will be semi-structured and will inquire about your personal feelings and experiences with Métis in the Maritimes. If you consent to me doing so, I would also like to make an audio recording of our interview.

Participating in this research poses minimal risk to participants, though your statements could lead to social, economic, psychological and/or emotional harm if they are attributable to individual persons or organizations. I am sensitive to these risks and I will implement all necessary measures to ensure your privacy and anonymity. All information you provide to me will be kept securely stored and responses will not be attributed to participants but rather attributed to pseudonyms to protect your identity. While all measures will be taken to protect your identity, if you are in a position of authority, there is a risk that your identity could be discovered, due to the nature of your position within the organization and/or community. I will be the only person will access to the data, which I will keep securely stored.

Participants may withdraw from the interview at any time, and have a subsequent window of 3 months from the date of the interview to withdraw their statements (in whole or in part). If you do choose to withdraw from the study, any information you provided to me will be destroyed. You also have the right to refuse to answer any question. When this project is completed, you will be notified as to where the results can be accessed. Data and findings will be securely stored in the student's private filing cabinet to be used for future research on this topic. If I wish to use this data for any other projects I will contact you for your permission.

Participation in this study will contribute to the development of increased knowledge of history and relations in the region and existence of Métis identity in the Maritimes. Furthermore, your participation will contribute to the increased understanding of the distinct identities of the Métis, Mi'kmaq and the Acadians who are involved in these complex historically rooted relations. This research will be presented in a Master's thesis in Anthropology, articles and in conference presentations.

Do you have any questions or need clarification on any points I have provided?

Do you voluntarily consent to participate in the study as described?

Do you consent to be audio recorded?

May we begin? 


\section{Appendix F: Termes Amérindiens dans le Parler Acadien}

atoka
babiche
bagaimou, bargamo
bîchecouette(?)
balamechcouèche, bonhommecoucèche
bénéri, boneri(?)
boucane, boucaner, boucanière
cablèche
cacagouèche
cacouit
canisteau, caristeau, gaspin
carcajou
caribou
cézain
chavèche
chicabenne
chicoutée
colibri
coucougouêche, kakigouêche, cocouêche,
chavèche
cowedge
doré, doris
gaspareau
hamatack, tamarack
katikiou
kékîche(?)
machequoui
maudouesse
marinqouin
maskabina
and

\author{
maskboûne \\ machecouêche \\ mataché \\ mêmetchai \\ mémetchai \\ minetchîche \\ micouenne \\ mitasse \\ mocazûne, mocassin \\ mocauque(s) \\ moïac \\ nagane \\ nigogue \\ nijagan \\ orignâ \\ ouarwari \\ ouaouaron \\ pagaye \\ pimbina \\ pirogue \\ plagouille, plogueuil \\ poulaman \\ rigouêche \\ sagouin, sagon \\ sagamité \\ savêche \\ savoyanne \\ skonse, squonque, skunk \\ tamarin \\ tawaye, taoueille
}


tignashy

tabagane

tomahawk

topinambour

Source: Brun, R. (2003). Les Acadiens

Avant 1755: Essai. Moncton: Regis Brun,

p. 118-120. 


\section{Appendix G: Termes Acadien dans le Parler Mi'kmaq}

\begin{tabular}{|c|c|}
\hline adieu & corde \\
\hline assiette & crème \\
\hline atout (jeu de cartes) & cruche \\
\hline avoine & demi \\
\hline bapisté & demiard (mesure) \\
\hline baquet & dime \\
\hline baril & douzaine \\
\hline bâtard & eau bénite \\
\hline bière & éclaireur \\
\hline bobine & évêque \\
\hline boisseau & fête \\
\hline bonjour & fromage \\
\hline bol, tasse & fuseau \\
\hline bonne année & gabegir \\
\hline bonsoir & gagner \\
\hline bouc & galette \\
\hline boucane & gallon \\
\hline vouteille & goélette \\
\hline brosse & grange \\
\hline beurre & hareng \\
\hline capitaine & hostie \\
\hline carêmw & jean-baptiste (jeu de cartes) \\
\hline carreau (jeu de cartes) & jeûne \\
\hline catéchisme & journal \\
\hline cave & juif \\
\hline châle & $\operatorname{lin}$ \\
\hline charité & magasin \\
\hline charpentier & mantelet \\
\hline cheminée & marchand \\
\hline chimise & mariée \\
\hline cheval, chevaux & marié \\
\hline chèvre & marteau \\
\hline chopine & matelot \\
\hline cinquante (monnaie) & messe \\
\hline clou & morceau \\
\hline
\end{tabular}




$$
\begin{aligned}
& \text { moulin (scierie) } \\
& \text { moulin à coudre } \\
& \text { mouchoir } \\
& \text { moutarde } \\
& \text { pain sucré (gâteau) } \\
& \text { patate } \\
& \text { pâté } \\
& \text { patriarche (prêtre) } \\
& \text { perroquet } \\
& \text { piastre }
\end{aligned}
$$

Source: Brun, R. (2003). Les Acadiens

Avant 1755: Essai. Moncton: Regis Brun, p. 120-123. 


\section{Appendix H: Wampano-Quiripi Vocabulary}

\author{
Counting \\ zero/nothing - machàge \\ one - nukut \\ two - nees \\ three - swe \\ four - youh \\ five - nappa \\ six - nukuddask \\ seven - nesausak \\ eight - swah \\ nine - pasakogun \\ ten - paiâg
}

\section{Time}

Sunday -Sundauk or Aramina-kigigatwi Monday - Mondauk or Nukut-kigigatwi Tuesday -Tuesdauk or Nees-kigigatwi Wednesday - Wednesdauk or Swekigigatwi

Thursday - Thursdauk or Youhkigigatwi

Friday - Fridauk or Nappa-kigigatwi

Saturday - Saturdauk or

Wuwusinnamanak-kigigatwi

January - (Wolf Moon) - Malsum-kesos

February - (Thawing Moon) - Michokatkesos

March - (Goose Moon) - Hakenah-kesos

April - (Fish Moon) - Operamac-kesos

May - (Planting Moon) - Reokkechankesos

June - (Strawberry Moon) -

Wotahomon-kesos

July - (Lobster Moon) - Ashaunt-kesos

August - (Ripe Moon) - Kesanoota-

kesos

September - (Harvest Moon) -

\section{Kepenum-kesos}

October (Eel Moon) - Neeshauog-kesos

November (Frost Moon) - Taquattin-

kesos

December (Long Moon) - Quinne-kesos

morning/daybreak - pawtumpung

noon - punghqsquaookqhquah

night - toopku

midnight - pungsquaununwukk

today - èa kesuk

tomorrow - nompung

yesterday - wunnonkou

a month - kesos

a year - kudtumoo

feast day/holiday - nickommo

Kici Mandoo - Great Spirit

Kehanit - Creator

friend (male) - ne'tomp

friend (female) - ne'tompas

man - ren

beaver - tummunk

island - munhan

berry - min

animal - oppishaun

bird - sibs

fish - amereck

plant - maskituash

vegetables - agwizid

tree - tukh

tobacco - assema

rock - m'numksquo

bear - makwa

deer - hat'k

moose - mooz

wolf - mukwoshim 




The Lord's Prayer in the Language of the Wampanoag

Noshun kesukqut,

Wunneetupantamunach koowesuonk.

Peyaumœutch kukkeitass $\infty$ tamœonk.

Toh anantaman ne naj okheit, neane kesukqut.

Ásekesukokish petukqunnegash assaminnean yeu kesukok

\begin{abstract}
Ahquontamaiinnean nummatcheseongash, neane matchenehikqueagig nutahquontamanóunonog.
\end{abstract}

\begin{abstract}
Ahque sagkompagininnean en qutchhuaonganit, webe pohquohwussinnan wutch matchitut;

Newutche keitass $\infty$ tam $\infty$ onk, kutahtauun, menuhkesuonk, sohsúmóonk michéme kah michéme.
\end{abstract}

Aho.

Source: http://nswampanoagnsmetis.org/languag e.html 